\title{
Optimization of Tetrahydroindazoles as Inhibitors of Human Dihydroorotate Dehydrogenase and Evaluation of Their Activity and In Vitro Metabolic Stability
}

Gergana Popova,* Marcus J. G. W. Ladds, Lars Johansson, Aljona Saleh, Johanna Larsson, Lars Sandberg, Sara Häggblad Sahlberg, Weixing Qian, Hjalmar Gullberg, Neeraj Garg, Anna-Lena Gustavsson, Martin Haraldsson, David Lane, Ulrika Yngve, and Sonia Lain

Cite This: J. Med. Chem. 2020, 63, 3915-3934

Read Online

ACCESS 1

Llll Metrics \& More

Article Recommendations

Supporting Information

ABSTRACT: Human dihydroorotate dehydrogenase (DHODH), an enzyme in the de novo pyrimidine synthesis pathway, is a target for the treatment of rheumatoid arthritis and multiple sclerosis and is re-emerging as an attractive target for cancer therapy. Here we describe the optimization of recently identified tetrahydroindazoles (HZ) as DHODH inhibitors. Several of the HZ analogues synthesized in this study are highly potent inhibitors of DHODH in an enzymatic assay, while also inhibiting cancer cell growth and viability and activating p53-dependent transcription factor activity in a reporter cell assay. Furthermore, we demonstrate the specificity of the compounds toward the de novo pyrimidine synthesis

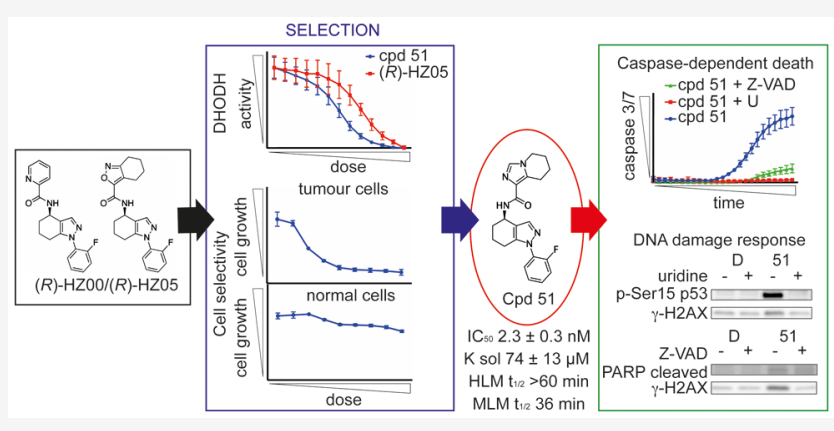
pathway through supplementation with an excess of uridine. We also show that induction of the DNA damage marker $\gamma$-H2AX after DHODH inhibition is preventable by cotreatment with the pancaspase inhibitor Z-VAD-FMK. Additional solubility and in vitro metabolic stability profiling revealed compound $\mathbf{5 1}$ as a favorable candidate for preclinical efficacy studies.

\section{INTRODUCTION}

Cellular pyrimidine ribonucleotide pools are maintained through both de novo synthesis and salvage pathways. DHODH, the only monofunctional enzyme in the de novo pyrimidine synthesis pathway, is located in the inner mitochondrial membrane. The enzyme catalyzes the only redox reaction in the pathway; the oxidation of dihydroorotate to orotate using ubiquinone $\left(\mathrm{Q}_{10}\right)$ as an electron acceptor. ${ }^{1,2}$ The final product of the pathway, uridine monophosphate (UMP), can also be synthesized via the pyrimidine nucleotide salvage pathways that rely on uridine import, deamination of cytidine to uridine, or by recycling of RNA. ${ }^{3}$

Depending on the cell type, growth rate, and the phase of the cell cycle, the nucleotide requirements of cells vary. ${ }^{4-6}$ Therefore, rapidly proliferating cells, such as cancer cells or activated $\mathrm{T}$ and $\mathrm{B}$ cells, may be highly sensitive to inhibition of nucleotide synthesis. ${ }^{7}$ Consequently, the enzymes in the de novo pyrimidine ribonucleotide synthesis pathway, and DHODH as part of the pathway, have been considered as attractive targets for the treatment of cancer and autoimmune diseases, as well as for the treatment of viral infections. ${ }^{8-11}$

The pro-drug leflunomide and its active metabolite teriflunomide (A771726) (Figure 1) are used in the clinic for the treatment of rheumatoid arthritis and multiple sclerosis, respectively. ${ }^{12,13}$ These DHODH inhibitors, however, have known off-target effects. ${ }^{14,15}$ Another well-studied inhibitor of DHODH is brequinar (Figure 1). First described in the 1980s, this compound showed antitumor activity in multiple cell lines and in murine tumor models. ${ }^{9,16}$ Phase II clinical trials using brequinar against solid tumors revealed modest to no effect. ${ }^{17-19}$ However, recent studies in hematological malignancies demonstrated therapeutic potential in preclinical models and have renewed interest in the use of DHODH inhibitors for the treatment of cancer. ${ }^{10}$ Other compounds that inhibit human DHODH have also been developed, ${ }^{20-22}$ and numerous studies have been carried out to improve the specificity, potency, and preclinical properties of these inhibitors. ${ }^{23-27}$ Currently, several DHODH inhibitors, including BAY2402234 (clinical trial identifier: NCT03404726) and ASLAN003 (clinical trial identifier: NCT03451084), are in clinical trials for the treatment of myeloid malignancies. ${ }^{28,29}$

Received: October 25, 2019

Published: March 26, 2020 


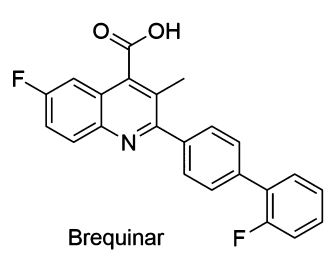<smiles>Cc1oncc1C(=O)Nc1ccc(C(F)(F)F)cc1</smiles><smiles>CC(O)=C(C#N)C(=O)Nc1ccc(C(F)(F)F)cc1</smiles><smiles>CCn1c(CO)nn(-c2cc(OC(C)C(F)(F)F)c(C(=O)Nc3c(F)cccc3Cl)cc2F)c1=O</smiles>

BAY2402234
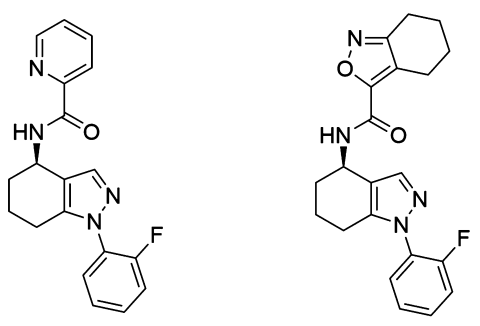

(R)-HZOO

(R)-HZ05

Figure 1. Structures of DHODH inhibitors.
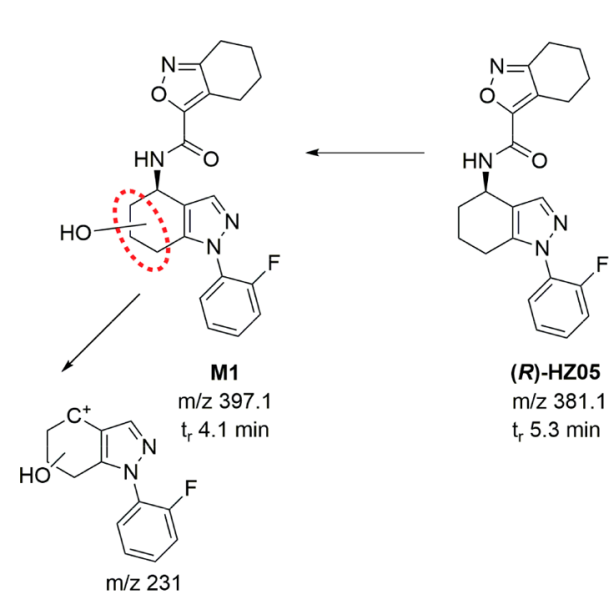

$\mathrm{m} / \mathrm{z} 381.1$

tr $5.3 \mathrm{~min}$
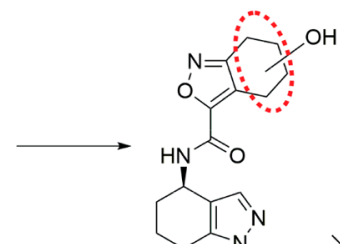

$\mathrm{H}$

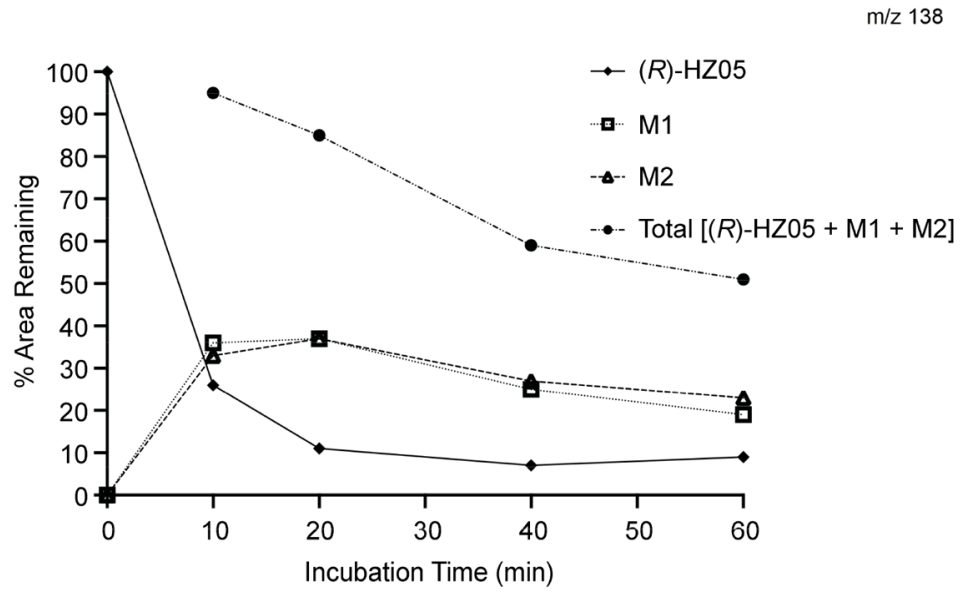

Figure 2. Metabolite formation after incubation of $(R)$-HZ05 with mouse liver microsomes. Two major metabolites, M1 and M2, were formed by hydroxylation. The exact position of the oxidation could not be determined; however, MS/MS analysis suggested hydroxylation of the two saturated rings in the structure.

Recently, chiral tetrahydroindazoles (HZ) were identified as a novel class of human DHODH inhibitors. ${ }^{30}(R)-\mathrm{HZ} 00$, which has a pyridyl $\mathrm{Ar}^{1}$ substituent, and its analogue $(R)$ $\mathrm{HZ05}$, with a tetrahydrobenzisoxazolyl $\mathrm{Ar}^{1}$ substituent (Figure 1), inhibited DHODH activity and, together with an inhibitor of p53 degradation, reduced melanoma cell growth in vivo. ${ }^{30}$
The originally identified hit compound HZ00 showed good metabolic stability in human liver microsomes. ${ }^{30}$ The in vivo studies with the more potent analogue $(R)-\mathrm{HZ} 05,{ }^{30}$ however, demonstrated that further medicinal chemistry optimization would facilitate the $\mathrm{HZ}$ compound class to progress toward in vivo efficacy studies in mouse models. In this paper, we report 
lead compound development through a structure-activity relationship (SAR) study of the $\mathrm{HZ}$ series. In addition, we provide data suggesting that the appearance of the DNA damage marker $\gamma$-H2AX in response to DHODH inhibition is not due to the induction of DNA damage, but rather to the onset of apoptosis. On the basis of the activity of the compounds in cells, as well as their solubility and in vitro metabolic stability, we identified compound $\mathbf{5 1}$ as a potent and selective DHODH inhibitor from which a compound with candidate drug properties may be developed.

\section{RESULTS AND DISCUSSION}

Rationale for the Design of New HZ Analogues. The design of new $\mathrm{HZ}$ analogues with potentially improved solubility and metabolic stability was based on a metabolic soft spot identification study performed with $(R)-H Z 05$. The disappearance of the compound and the formation of metabolites after incubation with mouse liver microsomes in the presence of NADPH was monitored by LC-MS/MS. A structural elucidation of the MS fragments, based on the detected two major oxidation products, suggested monohydroxylation of either the tetrahydroisoxazole ring or the central tetrahydroindazole ring in approximately equal amounts (Figure 2). These results indicated that the metabolic profile could be improved by modifying the $\mathrm{Ar}^{1}$ moiety of the $\mathrm{HZ}$ series.

The previously published X-ray cocrystal structure of $(R)$ HZ05 with DHODH served as an important tool in the design of new $\mathrm{HZ}$ analogues. ${ }^{30}$ A $2 \mathrm{D}$ schematic representation of the binding pocket of cocrystallized DHODH with ligand $(R)$ $\mathrm{HZO5}$ is shown in Figure 3. According to the cocrystal structure, the major interaction between the ligand and the protein occurs between Arg136 of the enzyme and the amide carbonyl oxygen of $(R)$-HZ05 through a two-water molecule bridge. Furthermore, the structure indicated that a limited space might be available around the tetrahydro-benzisoxazolyl ring, occupying the inner part of the binding pocket. Thus, the introduction of small substituents on the $\mathrm{Ar}^{1}$ pyridyl or tetrahydro-benzisoxazolyl moieties of the $\mathrm{HZ}$ inhibitors was considered a possible strategy for making this part of the compound less prone to oxidative metabolism. Analysis of the $\mathrm{X}$-ray structure also suggested that adding an extra hydrogen bond acceptor in the HZ compounds could allow for a new interaction with Tyr356 (Figure 3). This hypothesis is supported by the fact that a hydrogen bond interaction between DHODH inhibitors and Tyr356 is found in several of the published structures, many available in the Protein Data Bank (PDB), for example, BAY2402234 and teriflunomide. ${ }^{29,31}$ Such modification could potentially facilitate interactions of ligands with decreased lipophilicity, increased aqueous solubility, and enhanced metabolic stability. Moreover, the meta-position of the $\mathrm{Ar}^{2}$ phenyl appeared feasible for extended substituents toward the surrounding solvent, which could allow for larger modification such as photoaffinity probe constructs.

Synthesis of Target Compounds 28-54. Target compounds 28-54 were prepared by amide coupling between substituted 1-phenyl-4,5,6,7-tetrahydro- $1 \mathrm{H}$-indazol-4-amines (1) and aromatic carboxylic acids using various coupling reagents such as HATU, HBTU, or T3P (Scheme 1). The substituted 1-phenyl-1,5,6,7-tetrahydro-4H-indazol-4-ones 410 were prepared from cyclohexadione and optionally substituted phenylhydrazines (3) using the method described by Guo et al. ${ }^{32}$ (Scheme 2). The ketones 4-10 were either

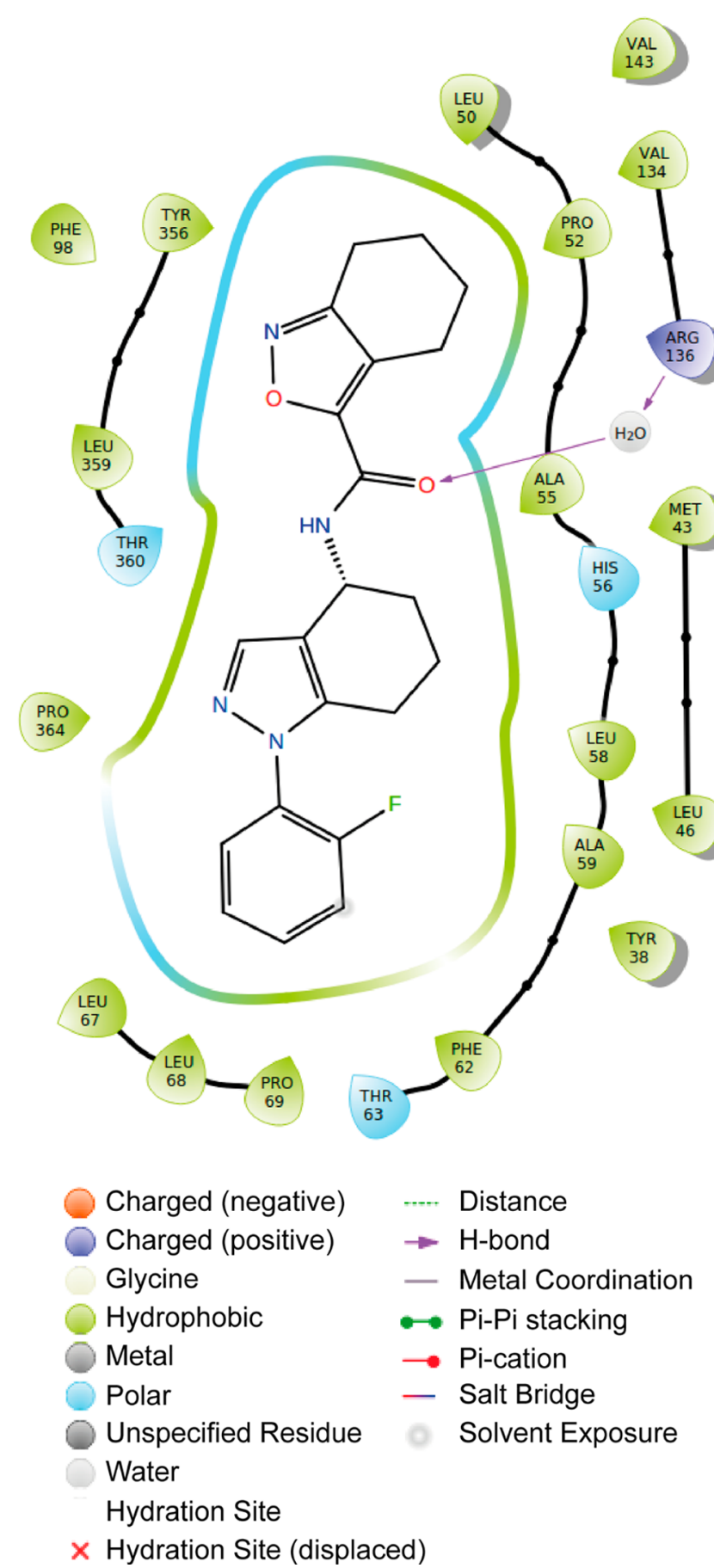

Figure 3. Ligand interaction diagram (LID). The LID (build on Maestro v.11.9, Schrödinger, LLC, New York, NY, 2019) shows a 2D schematic view of the binding pocket of the DHODH cocrystal structure with the ligand (R)-HZ05. ${ }^{30}$ A water-bridged interaction between the ligand amide carbonyl group and Arg136 is depicted in the diagram. Furthermore, Tyr356 is found top left in the near vicinity of the ligand $\mathrm{Ar}^{1}$ region. Solvent exposure of $(R)$-HZ05 is found at the $\mathrm{Ar}^{2}$ phenyl group in the meta position as indicated in gray on the ligand carbon atom and a break in the colored line drawn around the ligand representing the binding pocket.

reductively aminated using the method described by Guo et al. $^{32}$ to give the racemic 1-phenyl-4,5,6,7-tetrahydro- $1 \mathrm{H}$ indazol-4-amines 11-16 or first transformed to the chiral intermediates 17-20 using Ellman's sulfonamide and afterward reduced and deprotected as described in Ladds et al. ${ }^{30}$ to 
Scheme 1. Synthesis of Target Compounds $28-54^{a}$
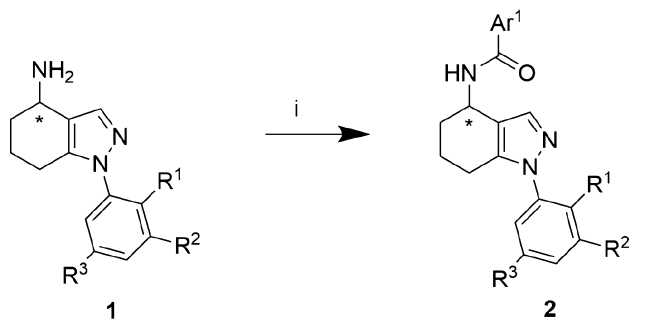

${ }^{a}(\mathrm{i}) \mathrm{Ar}^{1} \mathrm{COOH}, \mathrm{HATU}$, or HBTU or T3P, $\mathrm{Et}_{3} \mathrm{~N}$, or DIPEA.

give the chiral intermediates 21-24. The carboxylic acids used were commercially available, except compound 27 , which was prepared via palladium-mediated carbonylation (Scheme 3).

DHODH Inhibitory Activity of HZOO Analogues. The inhibitory activity of the newly synthesized $\mathrm{HZ}$ analogues against DHODH was tested in vitro by an optimized enzymatic assay ${ }^{30}$ that uses 2,3-dimethoxy-5-methyl-p-benzoquinone as a substitute for the highly insoluble coenzyme $Q_{10}$. The colorimetric kinetic reaction, which detects changes of the oxidation state of 2,6-dichlorophenolindophenol (DCIP) as a final electron acceptor, was monitored for $68 \mathrm{~min}$. The $\mathrm{IC}_{50}$ was calculated based on the estimated $V_{\max }$ values for each of the tested concentrations within a linear range using linear regression. The expansion of the $\mathrm{HZ}$ series was primarily focused on $(R)$-configured tetrahydroindazoles, i.e., analogues of the most potent HZ00 and HZ05 enantiomers (R)-HZ00 and (R)-HZ05, respectively (Figures S1-S2). First, we examined the effect of introducing various small substituents on the $\mathrm{Ar}^{1}$ pyridyl ring by synthesizing compounds 28-34 (Table 1). Both the 5-methyl analogue $28\left(\mathrm{IC}_{50}=55 \mathrm{nM}\right)$ and the 4-methyl analogue $29\left(\mathrm{IC}_{50}=34 \mathrm{nM}\right)$ showed significantly increased potency when compared to $(R)$-HZ00. Compounds with alternative small substituents in the 4-position, $\mathrm{CF}_{3}(30)$, $\mathrm{Cl}$ (31), $\mathrm{Br}$ (32), and $\mathrm{F}$ (33), exhibited similar potencies as 29, with compound 30 (Figure S1) being the most potent
Scheme 3. Synthesis of Carboxylic Acid $27^{a}$

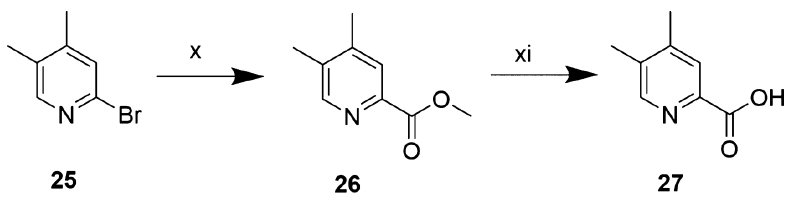

${ }^{a}(\mathrm{x}) \operatorname{Bis}($ acetato)bis $[o$-(di-o-tolylphosphino)benzyl $]$ dipalladium, tritert-butylphosphonium tetrafluoroborate, molybdenumhexacarbonyl, DBU, methanol, MW $120^{\circ} \mathrm{C}$; (xi) $\mathrm{LiOH}$ (aq), THF/methanol, rt.

analogue with an $\mathrm{IC}_{50}$ value of $15 \mathrm{nM}$. The 4,5-dimethyl analogue 34 was also slightly more potent than the 4-methyl compound 29. The introduction of larger substituents on the $\mathrm{Ar}^{1}$ pyridyl ring, exemplified by compound 35 , resulted in a decrease in potency, in agreement with the predictions from the analysis of the cocrystal structure between $(R)-\mathrm{HZO5}$ and DHODH (Figure 3).

In an attempt to reduce the lipophilicity, and potentially increase the metabolic stability, an additional nitrogen was introduced in the $\mathrm{Ar}^{1}$ heterocyclic moiety by the synthesis of the pyrimidinyl analogue 36 (Figure S1). However, this compound showed a decrease in $\mathrm{DHODH}$ inhibitory potency when compared to $(R)-H Z 00$. Likewise, the racemic phenyl analogue 37 (Figure S1) was 3-4-fold less potent than the parent racemic compound HZ00.

Finally, we investigated the potency of three analogues with alternative substitution patterns on the $\mathrm{Ar}^{2}$ phenyl moiety. Compounds $38\left(\mathrm{Ar}^{2}=2\right.$-methylphenyl; Figure $\left.\mathrm{S} 1\right), \mathbf{3 9}$, and $\mathbf{4 0}$ $\left(\mathrm{Ar}^{2}=2\right.$-fluoro-5-methylphenyl), all inhibited DHODH with similar potencies as their parent 2-fluoromethyl analogues 29 and 30, respectively. In summary, the introduction of small lipophilic substituents on the $\mathrm{Ar}^{1}$ pyridyl ring of the $\mathrm{HZ}$ compounds increased the potency toward $\mathrm{DHODH}$, while replacing the $\mathrm{Ar}^{1}$ pyridyl with phenyl or pyrimidinyl substituents had an adverse effect.

Scheme 2. Synthesis of Starting Materials $4-24^{a}$

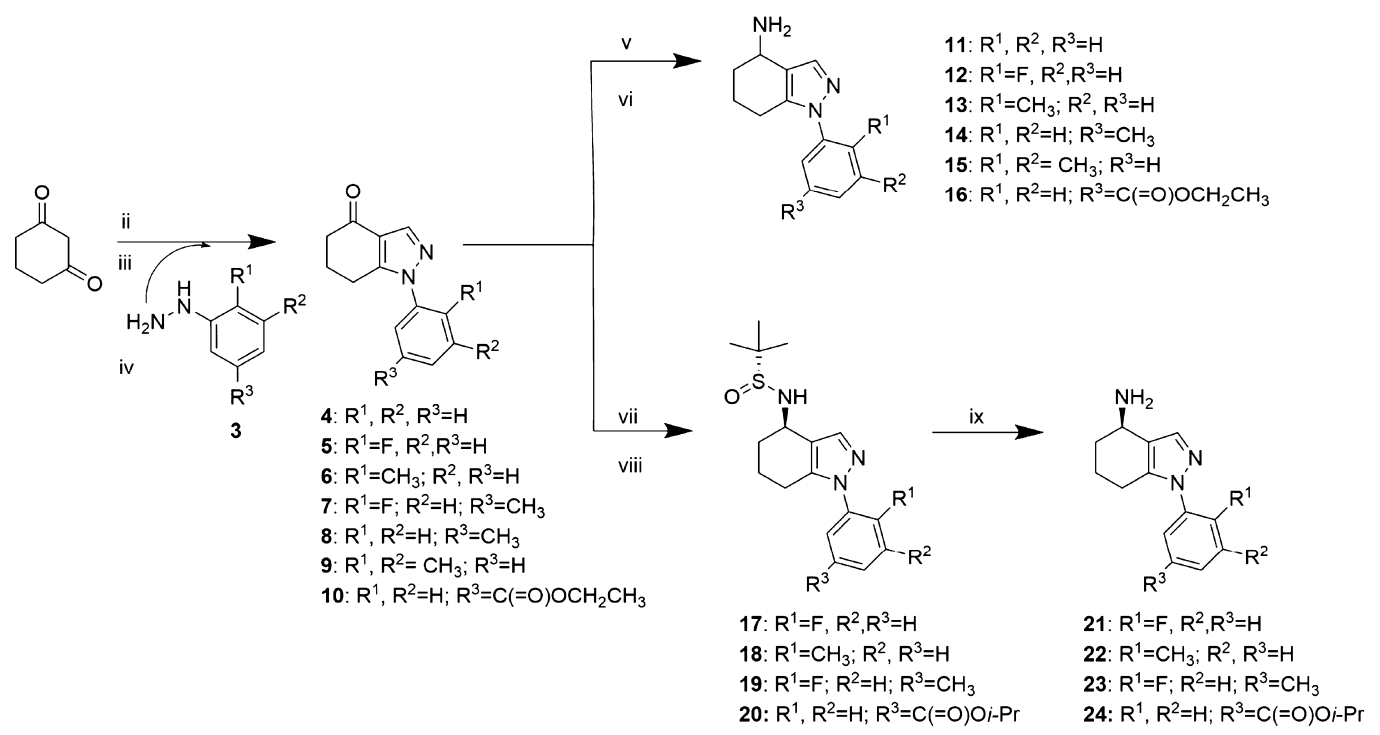

${ }^{a}$ (ii) N,N-Dimethylformamide dimethyl acetal, reflux; (iii) 3, sodium hydroxide, methanol, water, reflux; (iv) acetic acid, water, $120{ }^{\circ} \mathrm{C}$; (v) ammonium acetate, 2-propanol, rt; (vi) $4 \AA$ mol sieves, sodiumcyanoborohydride, $70{ }^{\circ} \mathrm{C}$; (vii) $\left(S_{S}\right)$-2-methyl-2-propanesulfinamide, $\mathrm{Ti}(\mathrm{OEt})_{4}$, THF, $75{ }^{\circ} \mathrm{C}$; (viii) L-Selectride, -48 to $0^{\circ} \mathrm{C}$; (ix) $\mathrm{HCl}$, methanol, rt. 
Table 1. Inhibitory Activity $\left(\mathrm{IC}_{50}\right)$ of $\mathrm{HZOO}$ Analogues on Human DHODH

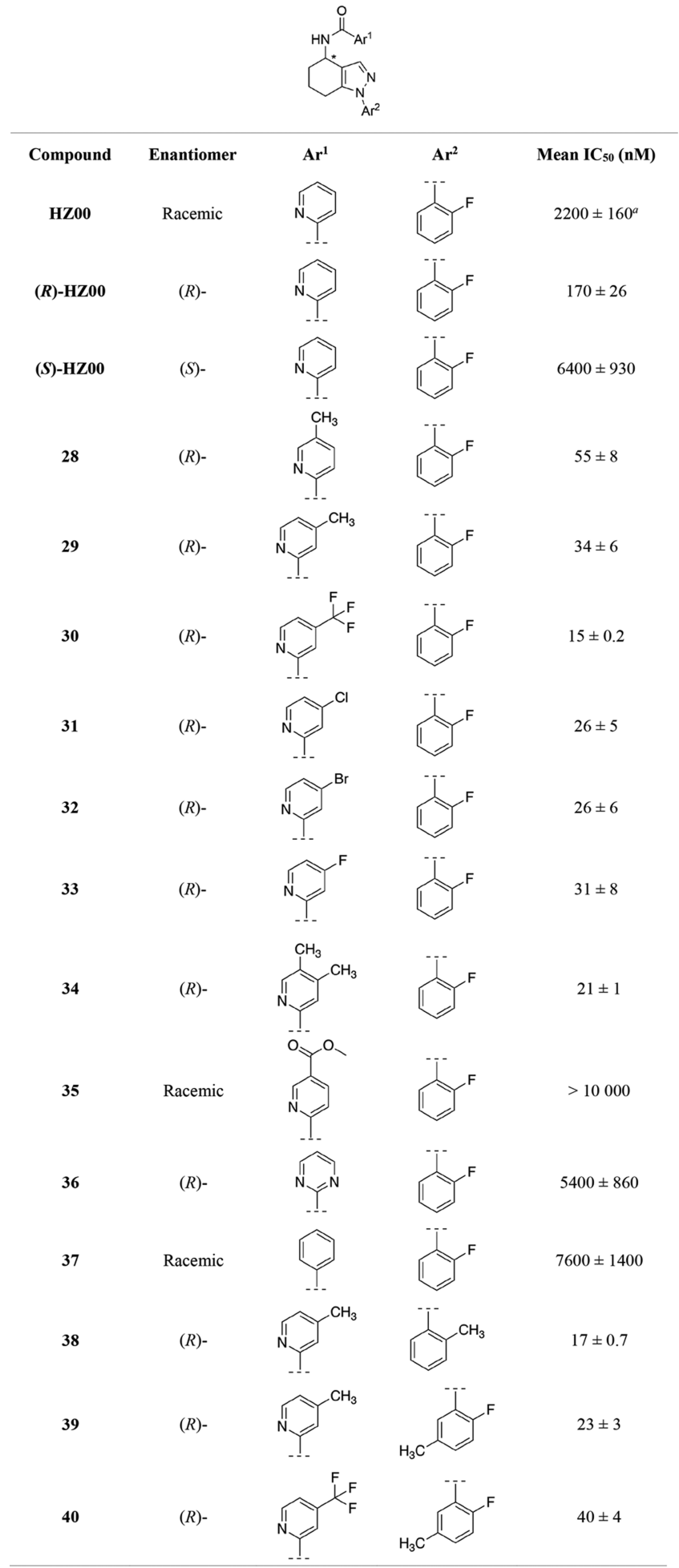

$a_{n}=2$; data taken from Ladds et al. ${ }^{30}$

DHODH Inhibitory Activity of HZ05 Analogues. The modifications introduced in the HZ00 series provided a base for the SAR of the more potent parent compound (R)-HZ05 (Figure S2a). Initially, we isolated the enantiomeric pair of the closely related regioisomers of (R)-HZ05 and (S)-HZ05, compounds 41 and 42, respectively, with reversed $\mathrm{N}$ and $\mathrm{O}$ positions in the $\mathrm{Ar}^{1}$ tetrahydro-benzisoxazolyl moiety. Both compounds were equipotent to their respective $(R)$ - and $(S)$ HZ05 counterparts (Table 2), again demonstrating the superior $\mathrm{DHODH}$ inhibitory properties of $\mathrm{HZ}$ compounds with $(R)$ configuration.

We also synthesized HZ05 analogues with alternative small, or no substituents on the $\mathrm{Ar}^{2}$ phenyl moiety, compounds 4350 (Figure S2b). In agreement with the SAR from the HZ00 series, these compounds showed similar or increased potencies in their inhibition of DHODH when compared to the parent HZ05 compounds.

The X-ray cocrystal structure of DHODH with $(R)-\mathrm{HZOS}^{30}$ suggested that an additional hydrogen bond acceptor in the $\mathrm{Ar}^{1}$ moiety of the $\mathrm{HZ}$ compounds might allow for a complementary interaction with the hydroxyl group of the DHODH residue Tyr356 (Figure 3). Therefore, in an attempt to facilitate an interaction with Tyr356 (Figure 3), and at the same time decrease the lipophilicity and potentially increase the metabolic stability of the compounds, the imidazopyridinyl analogues 51 (Figure S2b) and 52 were synthesized. In agreement with our theory, both compounds 51 and 52 were highly potent $\mathrm{DHODH}$ inhibitors, with $\mathrm{IC}_{50}$ values below that of $(R)$-HZ05. We have, however, no conclusive evidence that the improved potency of these analogues is due to an actual additional interaction between the inhibitors and Tyr356 residue of the enzyme. Nevertheless, the ligand-lipophilicity efficiency (Table S1), defined as the difference between the ligand $\mathrm{pIC}_{50}$ and $\log \mathrm{P}$, increases considerably from 4.6 for $(R)$ HZ05 to 5.6 for compound $\mathbf{5 2}$ and 5.7 for compound $\mathbf{5 1}$ due to a concurrent increase in $\mathrm{pIC}_{50}$ and decrease in $\log \mathrm{P}$.

The cocrystal structure also suggested that the meta position of the $\mathrm{Ar}^{2}$ phenyl group of the $\mathrm{HZ}$ compounds may allow for larger substituents directed out from the binding pocket opening toward the surrounding solvent (Figure 3). Thus, compounds $\mathbf{5 3}$ and $\mathbf{5 4}$ were synthesized, both with sterically demanding substituents in the meta position of the $\mathrm{Ar}^{2}$ phenyl group. Compound 53, containing an ester substituent on the aryl, was a potent $\mathrm{DHODH}$ inhibitor, illustrating the versatility of the cocrystal structure model as a guide for modifications of the HZ compounds. However, compound 54 (Figure S2a), containing a carboxylic acid substituent, showed low potency. These results imply that the meta position of the $\mathrm{Ar}^{2}$ phenyl group may be used to prepare, for example, photoactive or fluorescent-tagged compounds, useful in future cell studies of this compound series.

Solubility and In Vitro Metabolic Stability. Compounds $30,38,46$, and 51 , among the most potent inhibitors from the HZOO and HZ05 series, were further tested for their solubility and metabolic stability in human (HLM) and mouse liver microsomes (MLM). The results are summarized in Table 3.

Of the HZ compounds tested, compounds 38 and 51 exhibited high solubility in the Prima HT aqueous solubility test solution (Table 3 ). Compounds $\mathbf{4 6}$ and $\mathbf{3 0}$ were markedly less soluble and would demand more elaborate formulations for use in vivo.

Metabolic stability studies in liver microsomes were conducted with all four $\mathrm{HZ}$ compounds and brequinar, which was used as a reference. Compound $\mathbf{3 0}$ showed high stability in MLM; however, the result must be interpreted cautiously since the compound demonstrated low aqueous solubility. Compounds $\mathbf{3 8}$ and $\mathbf{5 1}$ both had a half-life of more than $60 \mathrm{~min}$ in HLM, and compound 51 demonstrated the 
Table 2. Inhibitory Activity $\left(\mathrm{IC}_{50}\right)$ of HZ05 Analogues on Human DHODH

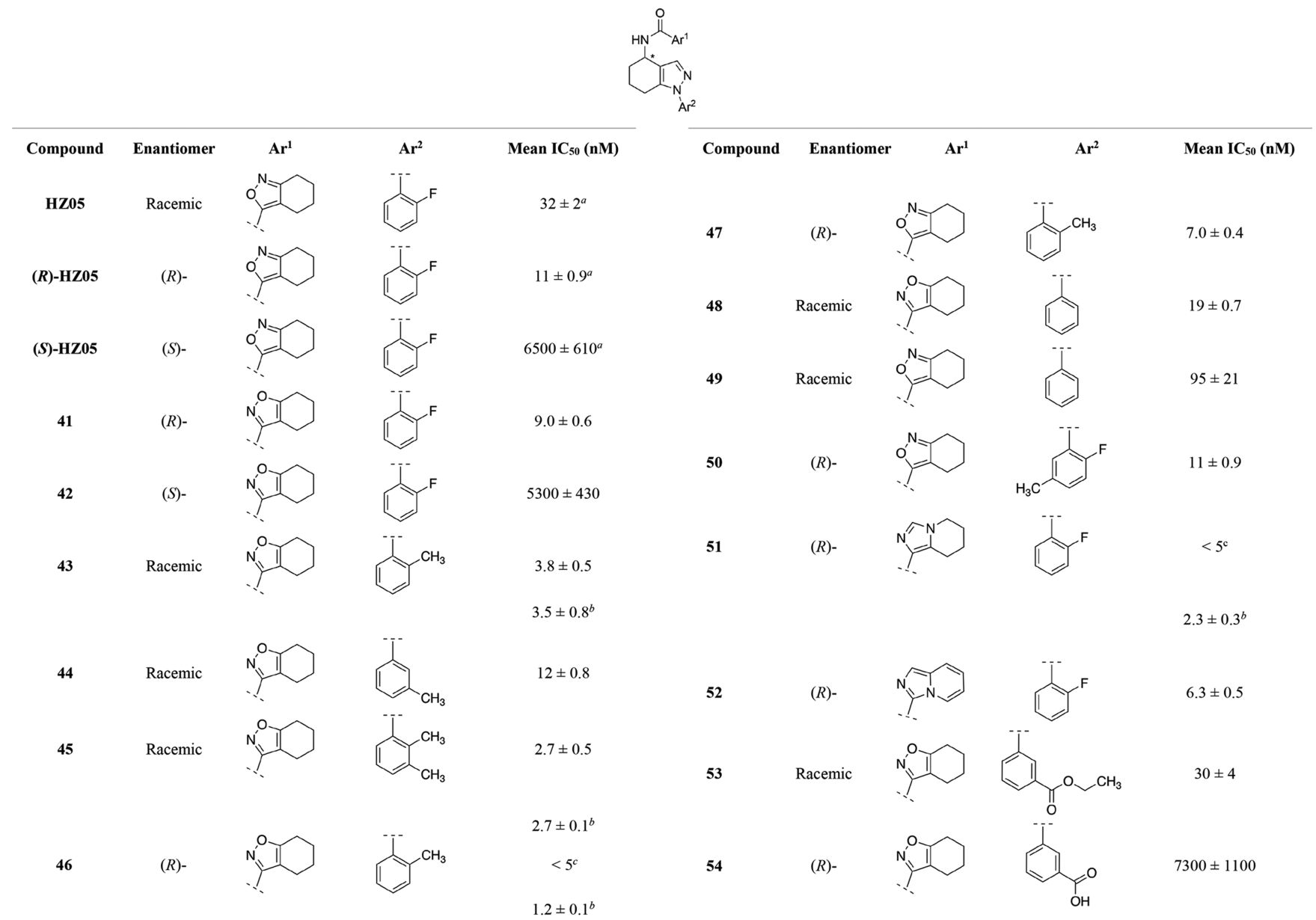

${ }^{a}$ Data taken from Ladds et al. ${ }^{30} b_{2} \mathrm{nM}$ enzyme used in the enzymatic assay. ${ }^{c} n=1$.

Table 3. Solubility and In Vitro Metabolic Stability of $(R)$ HZ00 and (R)-HZ05 Analogues

$\begin{array}{lcccc} & \begin{array}{c}\text { mean } \mathrm{IC}_{50} \\ \text { enzymatic } \\ \text { assay }(\mathrm{nM})\end{array} & \begin{array}{c}\text { K solubility } \\ \text { at } \mathrm{pH} \mathrm{7.4}(\mu \mathrm{M})\end{array} & \begin{array}{c}\text { metabolic } \\ \text { stability HLM: } \\ t_{1 / 2}(\mathrm{~min})\end{array} & \begin{array}{c}\text { metabolic } \\ \text { stability MLM: } \\ t_{1 / 2}(\mathrm{~min})\end{array} \\ \begin{array}{llll}\text { compound } \\ (R)-\mathrm{HZ00}\end{array} & 170 \pm 26^{a} & & >60 & 1 \pm 0.2 \\ (R)-\mathrm{HZ05} & 11 \pm 0.9^{a} & 15 & 85 \pm 28 & 8 \pm 1 \\ \text { brequinar } & 1.8 \pm 0.3^{b} & 110 \pm 7 & >60 & \mathrm{NC} \\ 30 & 15 \pm 0.2 & <5 & \mathrm{NC} & 54 \\ 38 & 17 \pm 0.7 & 110 \pm 14 & >60 & 10 \\ 46 & 1.2 \pm 0.1^{b} & 10 \pm 2 & 23 & 6 \\ 51 & 2.3 \pm 0.3^{b} & 74 \pm 13 & >60 & 36\end{array}$

${ }^{a}$ Data Ladds et al. ${ }^{30} b_{2} \mathrm{nM}$ enzyme used in the enzymatic assay. NC: not calculated as compound was stable within the duration of experiment.

highest stability in MLM of the two with a half-life of $36 \mathrm{~min}$. Compound 46 showed the lowest stability in both HLM and MLM. These results, in combination with the measured aqueous solubilities, suggest that compound $\mathbf{5 1}$ has the best properties to allow preclinical mouse studies in the future. Additionally, compound $\mathbf{5 1}$ was tested against a panel of 468 kinases at a concentration of $1 \mu \mathrm{M}$. The results from this screen (Table S2) support that the compound might be a specific inhibitor of DHODH.

Activation of the Transcription Factor Function of p53 in Cells. (R)-HZ00 and its analogue HZ05 were identified as inducers of the transcription factor activity of p53 in the ARN8 p53-reporter melanoma cell line (Figure S3). ${ }^{30}$ Therefore, the ability of selected $\mathrm{HZ}$ analogues and brequinar (used as a reference) to activate p53-induced transcription was tested in this reporter cell line in the p53 reporter assay (CPRG assay). As shown in Figure 4, compounds $30,38,43,45$, and 51 , the most active analogues in the enzymatic assay from the HZ00 series and the HZ05 series, were all potent activators of p53-dependent transcription in ARN8 cells. Furthermore, supplementation with high concentrations of uridine $(100 \mu \mathrm{M})$ prevented the activation of p53-dependent transcription, suggesting that the increased activity of p53 after treatment with the $\mathrm{HZ}$ compounds is due to inhibition of the de novo pyrimidine ribonucleotide synthesis pathway. ${ }^{33}$ At higher concentrations, however, some of the compounds, such as 43 and 45 (Figure $4)$, caused a decrease in the detected p53 reporter activity. Compound 46 (Figure S3), the ( $R$ )-enantiomer of 43, showed similar activity to the racemic analogue, including a p53 activity decrease at higher concentrations. The reduction observed with the strongest inhibitors from the series might be explained by a decrease in cell growth or viability, thus leading to a lower level of p53 transcription factor function.

The analogues, which had low activity in the in vitro enzymatic assay, did not induce p53-dependent transcription (Figure S3). This is also exemplified by the enantiomeric pairs 
ARN8
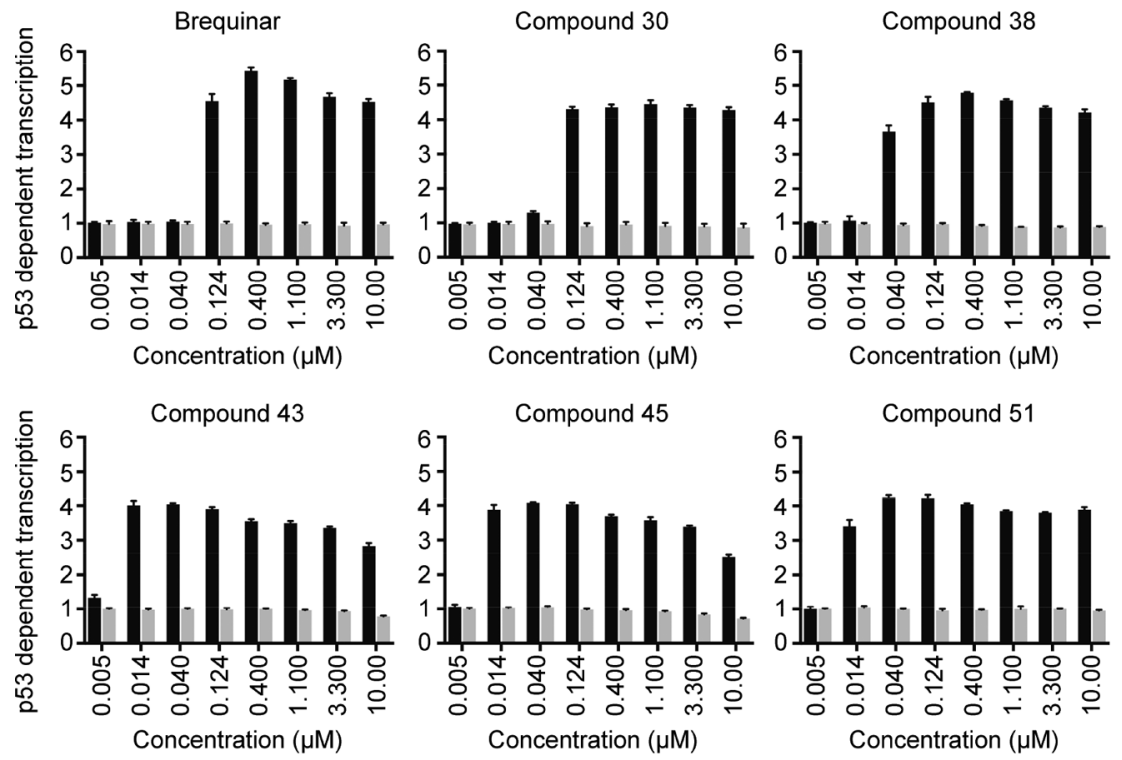

No Uridine Uridine $(100 \mu \mathrm{M})$

Figure 4. HZ analogues induce p53-dependent transcription. ARN8 cells were treated with the indicated compounds for $16 \mathrm{~h}$ in a medium supplemented with $100 \mu \mathrm{M}$ uridine or without supplementation. The induction of p53-dependent transcription was measured using the $\beta$ galactosidase CPRG substrate as described. Values correspond to the average of three technical replicates \pm SD. The experiments are representative of at least two independent biological replicates.

of $(R)$ - and $(S)$-HZ00 and HZ05, where only the active $R$ enantiomers had an effect on p53-dependent transcription.

Effect of $\mathrm{HZ}$ Analogues on Cell Growth/Viability. Following the activity studies of the compounds on the isolated DHODH enzyme and testing their ability to activate the transcription factor function of p53 in cells, we analyzed the effect of $\mathrm{HZ}$ analogues with an $\mathrm{IC}_{50}<20 \mathrm{nM}$ against purified DHODH, on the viability of two cell types: ARN8 melanoma cells (Table 4 and Figure 5a) and human normal dermal fibroblasts (HNDFs; Table 4 and Figure 5b). Brequinar (Figure 5) $)^{16,34}$ was again used as a reference compound (Table 4). Compounds with low or no activity in the enzymatic assay were also tested for their effect on the viability of ARN8 and HNDFs (Figure S4).

The HZ00 analogues with the highest activity in the enzymatic assay, compounds $\mathbf{3 0}$ and $\mathbf{3 8}$, were more potent than $(R)-\mathrm{HZO0}$ (Figure S4a) at reducing the growth/viability of ARN8 cells as measured by a sulforhodamine B (SRB) assay. Furthermore, these analogues had little or no effect on the growth/viability of HNDFs at the tested concentrations within 72 h of treatment. Compounds 36, 37, and (S)-HZ00, which had low inhibitory activity in the in vitro enzymatic assay, had little or no effect on both cell lines at the tested concentrations (Figure S4).

Most of the tested HZ05 analogues showed improved or similar growth/viability inhibitory activities in ARN8 cells when compared to their racemic and enantiomeric parent counterparts HZ05 and (R)-HZ05 (Table 4, Figure 5, Figure S4). In contrast, when the new analogues were tested for growth/viability inhibition in HNDF cells, only weak effects were observed at the higher concentrations. These results show that the compounds are more toxic for ARN8 melanoma cells than for normal fibroblasts. Compounds 42 and (S)-HZ05, which had low inhibitory activity in the in vitro enzymatic
Table 4. Inhibitory Activity $\left(\mathrm{IC}_{50}\right)$ of $\mathrm{HZ}$ Analogues on Cell Growth/Viability of ARN8 Cells and HNDFs

$\begin{array}{lccc}\text { compound } & \begin{array}{c}\text { mean IC } \text { IC }_{50} \text { enzymatic } \\ \text { assay }(\mathrm{nM})\end{array} & \begin{array}{c}\text { mean IC } \mathrm{IC}_{50} \text { ARN8 } \\ \text { cells }(\mathrm{nM})\end{array} & \begin{array}{c}\text { mean } \text { IC }_{50} \\ \text { HNDFs }(\mathrm{nM})\end{array} \\ \text { brequinar } & 1.8 \pm 0.3^{a} & 400 \pm 36 & >10000 \\ \text { HZ00 } & 2200 \pm 160^{b, c} & 5400 \pm 1700^{d} & >10000 \\ (R)-\mathrm{HZ00} & 170 \pm 26 & 930 \pm 24 & >10000 \\ \text { HZ05 } & 32 \pm 2^{b} & 220 \pm 150^{d} & 8900 \pm 240^{e} \\ (R)-\mathrm{HZ05} & 11 \pm 0.9^{b} & 160 \pm 76 & >10000 \\ 30 & 15 \pm 0.2 & 110 \pm 25 & >10000 \\ 38 & 17 \pm 0.7 & 62 \pm 11 & >10000 \\ 41 & 9.0 \pm 0.6 & 80 \pm 15 & >10000 \\ 43 & 3.5 \pm 0.8^{a} & 15 \pm 9^{d} & 8600 \pm 950^{e} \\ 44 & 12 \pm 0.8 & 170 \pm 110 & 8000 \pm 330^{f} \\ 45 & 2.7 \pm 0.1^{a} & 23 \pm 11 & 7700 \pm 460^{f} \\ 46 & 1.2 \pm 0.1^{a} & 14 \pm 6^{d} & >10000 \\ 47 & 7.0 \pm 0.4 & 73 \pm 29^{d} & >10000 \\ 48 & 19 \pm 0.7 & 430 \pm 460^{d} & 7000 \pm 2700^{f} \\ 50 & 11 \pm 0.9 & 200 \pm 110^{d} & 6700 \pm 1200^{f} \\ 51 & 2.3 \pm 0.3^{a} & 22 \pm 8 & >10000 \\ 52 & 6.3 \pm 0.5 & 38 \pm 10 & 9400^{g}\end{array}$

${ }^{a}$ Enzyme concentration in the enzymatic assay was $2 \mathrm{nM}$. ${ }^{b}$ Data taken from Ladds et al. ${ }^{30} c_{n}=2 .{ }^{d} n=4 .{ }^{e}$ Mean \pm SD calculated based on 2 experiments, $n=5$. The $\mathrm{IC}_{50}$ in the other 3 was $>10000 .{ }^{f}$ Mean $\pm \mathrm{SD}$ calculated based on 3 experiments, $n=5$. The $\mathrm{IC}_{50}$ in the other 2 was $>10000 .{ }^{g} \mathrm{IC}_{50}$ was reached in 1 experiment, $n=4$. The $\mathrm{IC}_{50}$ in the other 3 was $>10000$.

assay, had little or no effect on both cell lines at the tested concentrations (Figure S4).

To establish whether the main effect of the compounds on cell growth/viability is due to DHODH inhibition, we tested whether their effect was prevented by the addition of a high concentration of uridine to the medium. Similar to the result obtained in the CPRG assay (Figure 4, Figure S3), we 

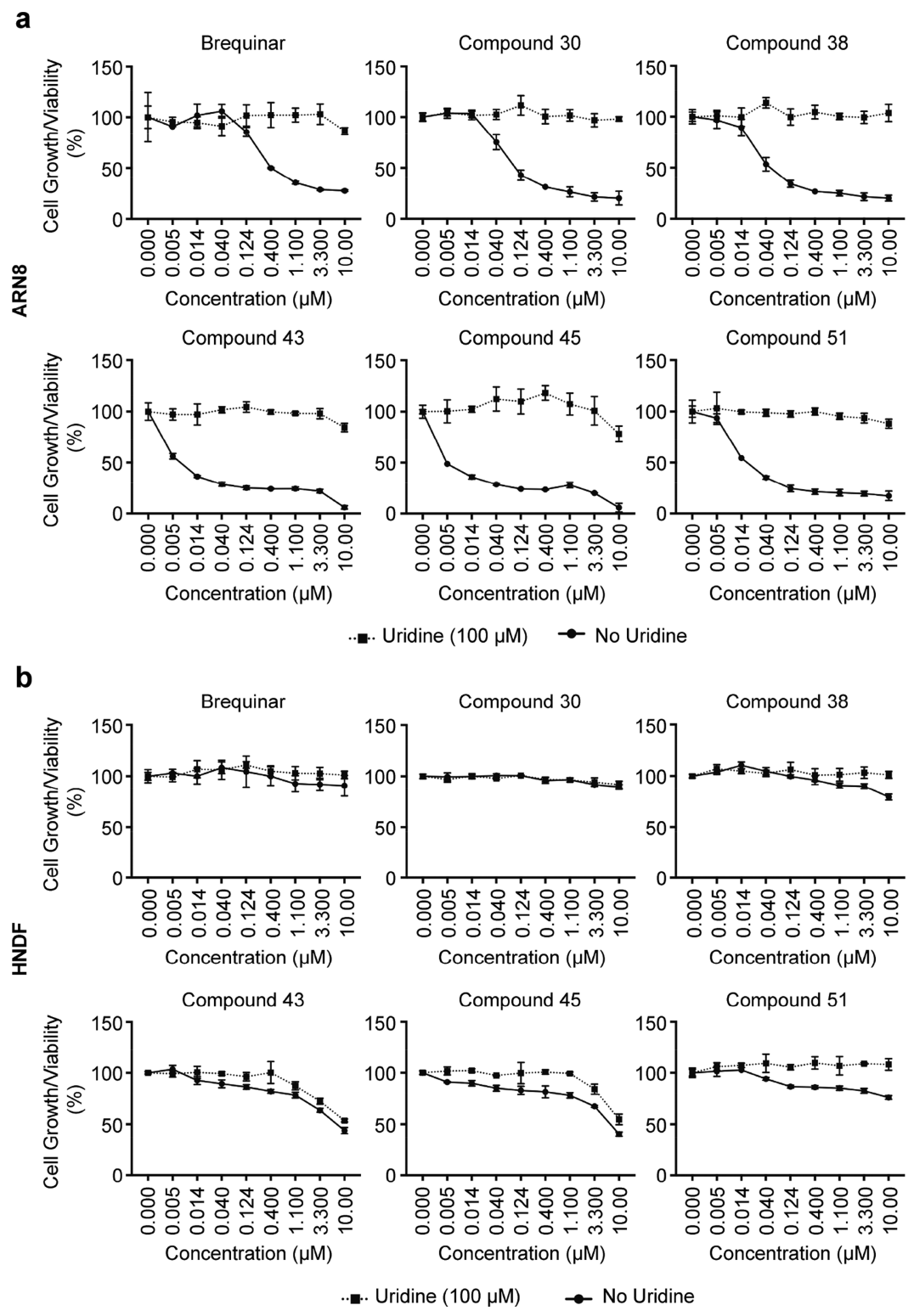

Figure 5. Effect of HZ analogues on cell growth/viability. (a) ARN8 cells or (b) HNDFs were treated with the indicated HZ00 and HZ05 analogues for $72 \mathrm{~h}$ in medium supplemented with $100 \mu \mathrm{M}$ uridine or without supplementation. The compounds effect on cell growth/viability was measured by SRB staining. Values correspond to the average of three technical replicates \pm SD. The experiments are representative of at least three independent biological replicates.

observed that supplementation with uridine allows cells to overcome the effect on cell growth/viability of the selected HZOO and HZ05 analogues, except at high concentrations of some compounds, such as 43, 45, and 46 (Figure 5; Figure S4). The results indicate that depletion of pyrimidine ribonucleotides, caused by inhibition of DHODH by the HZ compounds, leads to the increased activity of p53 and also to reduced growth/viability of ARN8 melanoma cells.

Effects on p53 Levels and $\gamma-\mathrm{H} 2 \mathrm{AX}$ Phosphorylation. Some of the $\mathrm{HZ}$ analogues with the strongest effect on cell growth/viability of ARN8 cells were selected for further analysis. Compound 51, with the overall most favorable potency and ADME-properties, and the racemic compounds 43 and $\mathbf{4 5}$ were used for the analysis of p53 protein levels. In agreement with their ability to increase p53-dependent transcription in ARN8 melanoma cells, compounds 43, 45, and 51 also increased p53 protein levels, and this was prevented by the addition of high concentrations of uridine (Figure 6a). A similar result was observed with brequinar. In contrast, the increase in p53 levels by compounds that have mechanisms of action other than DHODH inhibition, such as the $\mathrm{mdm} 2$ antagonist nutlin-3a $(\mathrm{N} 3 \mathrm{a})^{35,36}$ or the topoisomerase II inhibitor etoposide (ETP), ${ }^{37}$ was not prevented by the supplementation with uridine (Figure 6a).

An important consideration regarding the use of $\mathrm{DHODH}$ inhibitors in the clinic is whether they can cause damage to the genome. In the study of Ladds et al. ${ }^{30}$ an increase of DNA damage markers was not detected after treatment with HZOO. As the new $\mathrm{HZ}$ analogues are more potent, we re-examined several proteins associated with the DNA damage response. We checked whether cells treated with compounds 43,45 , and 51, or brequinar affected the levels of p53 phosphorylated at Ser15 (p-Ser15 p53), a marker for the activation and stabilization of $\mathrm{p} 53$ as a result of DNA damage, ${ }^{38-40}$ as well 


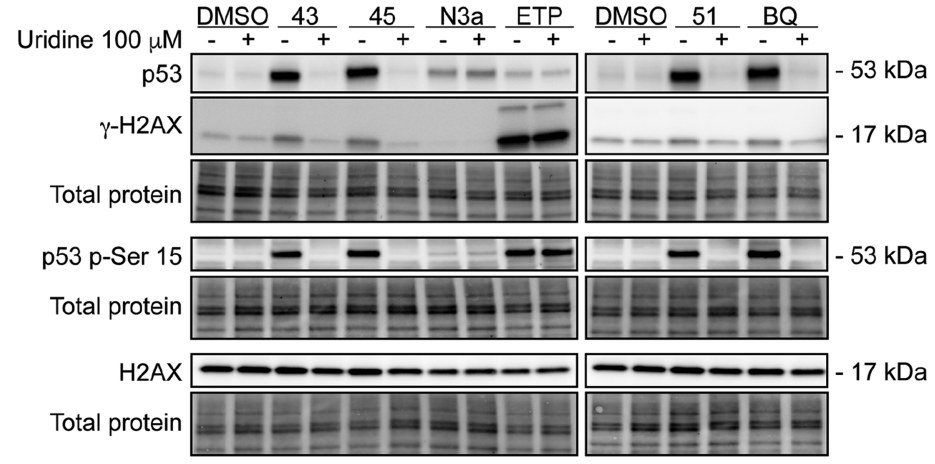

b

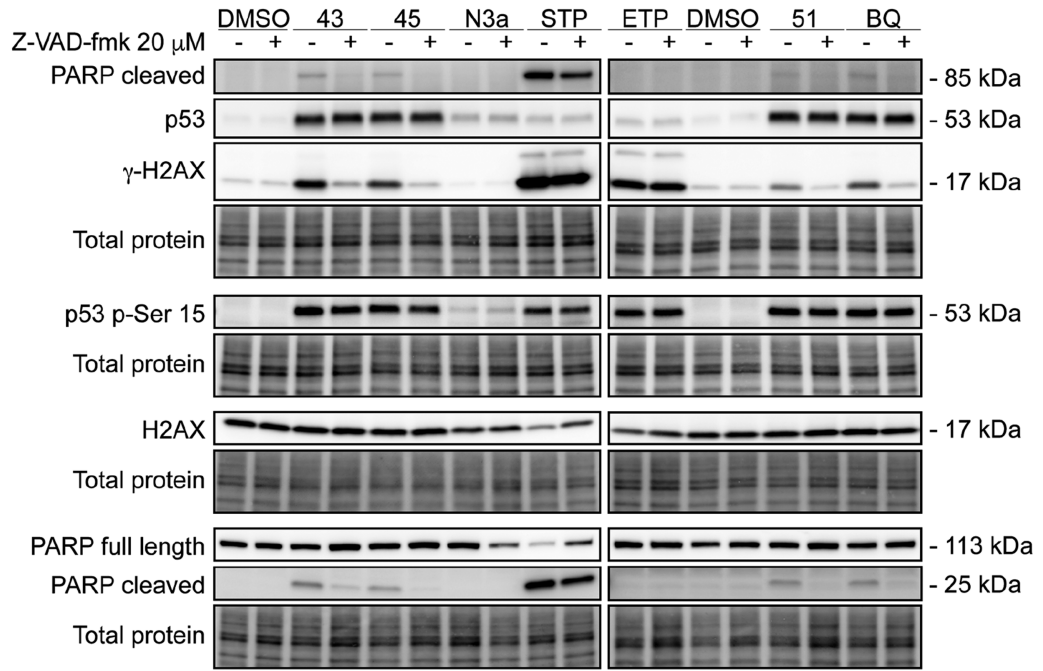

Figure 6. DHODH inhibitors induce apoptosis. (a) ARN8 cells were treated for $24 \mathrm{~h}$ with $20 \mathrm{nM}$ of compounds 43, 45, and 51, $250 \mathrm{nM}$ brequinar (BQ), or $2 \mu \mathrm{M}$ nutlin-3a (N3a). Treatment with $20 \mu \mathrm{M}$ etoposide (ETP) was carried out for $1 \mathrm{~h}$. Where indicated, the medium was supplemented with $100 \mu \mathrm{M}$ uridine. The protein levels of $\mathrm{p} 53$, p-Ser15 p53, and $\gamma$-H2AX and H2AX were analyzed by Western blotting. Loading was controlled by the amount of the total protein. (b) ARN8 cells were treated for $24 \mathrm{~h}$ with $20 \mathrm{nM}$ of compounds 43, 45, and 51, $250 \mathrm{nM}$ brequinar (BQ), or 2 $\mu \mathrm{M}$ nutlin-3a (N3a). Twenty $\mu \mathrm{M} \mathrm{Z}$-VAD-FMK or vehicle control were added $4.5 \mathrm{~h}$ prior to harvesting. Cotreatment with $20 \mu \mathrm{M}$ etoposide (ETP) with $20 \mu \mathrm{M} \mathrm{Z}$-VAD-FMK or vehicle was for $1 \mathrm{~h}$, and cotreatment with $1 \mu \mathrm{M}$ staurosporine (STP) and $20 \mu \mathrm{M}$ Z-VAD-FMK or vehicle was for 4.5 $\mathrm{h}$. The protein levels of cleaved PARP ( $85 \mathrm{kDa}$ fragment), p53, $\gamma$-H2AX, p-Ser $15 \mathrm{p} 53, \mathrm{H} 2 \mathrm{AX}$, and PARP (full length and $25 \mathrm{kDa}$ fragment) were analyzed by Western blotting. The total amount of protein was used as a loading control.

as H2AX phosphorylated at Ser139 ( $\gamma$-H2AX), a marker for double-strand DNA breaks. ${ }^{41,42}$ As shown in Figure 6a, the levels of both markers were increased after $24 \mathrm{~h}$ treatment with all DHODH inhibitors. These effects, however, were prevented by supplementation with high concentrations of uridine, suggesting that they result from inhibition of $\mathrm{DHODH}$ and that the compounds themselves most likely do not exert direct effects on DNA through mechanisms such as covalent modification of DNA bases or by drug-DNA intercalation. Treatment with etoposide, which induces double-strand DNA breaks, increased p-Ser15 p53 and $\gamma-\mathrm{H} 2 \mathrm{AX}$ levels regardless of uridine supplementation (Figure 6a).

Phosphorylation of p53 at Serine-15 has also been associated with the transcription factor function of $\mathrm{p} 53 .{ }^{43}$ An increase in p-Ser15 p53 was observed not only in DHODH inhibitortreated samples but also after treatment with the nongenotoxic p53 activator nutlin-3a (Figure 6). ${ }^{35,44}$ This increase in p-Ser15 p53, although lower in the $\mathrm{mdm} 2$ inhibitor-treated samples, was accompanied by a substantial rise in total p53 levels (Figure 6). Therefore, the increased p-Ser15 p53 observed after inhibition of DHODH is likely due to a basal level of phosphorylation of p53. In contrast, the DNA damaging agent etoposide (Figure 6), as well as staurosporine (Figure 6b), caused a more pronounced rise in p-Ser 15 p53 levels compared to levels of total p53.

Although the uridine supplementation demonstrated that the $\mathrm{HZ}$ compounds analyzed here are unlikely to directly damage DNA, this does not preclude the idea that targeting the de novo pyrimidine pathway and the subsequent pyrimidine ribonucleotide depletion affects DNA synthesis. A recent study by Mathur et al. $^{45}$ shows that Chk-1 is phosphorylated at Ser345 (p-Ser435) and $\gamma$-H2AX increases after treatment of PTEN mutant cancer cells with DHODH inhibitors. The study, in spite of using high concentrations $(100-150 \mu \mathrm{M})$ of leflunomide or teriflunomide (A771726), compounds with known off-target effects at high doses, ${ }^{14,15}$ suggested that inhibition of DHODH leads to cell death caused by chromosome breaks and DNA damage at replication forks. ${ }^{45}$ Therefore, we examined the levels of p-Ser345 Chk-1 and Chk-2 phosphorylated at Thr68 (p-Thr68 Chk-2) after 24 $\mathrm{h}$ treatment with the $\mathrm{HZ}$ compounds or brequinar (Figure S5). In our study, induction of p-Ser345 Chk-1 or p-Thr68 Chk-2 in response to inhibition of DHODH was not detected. 

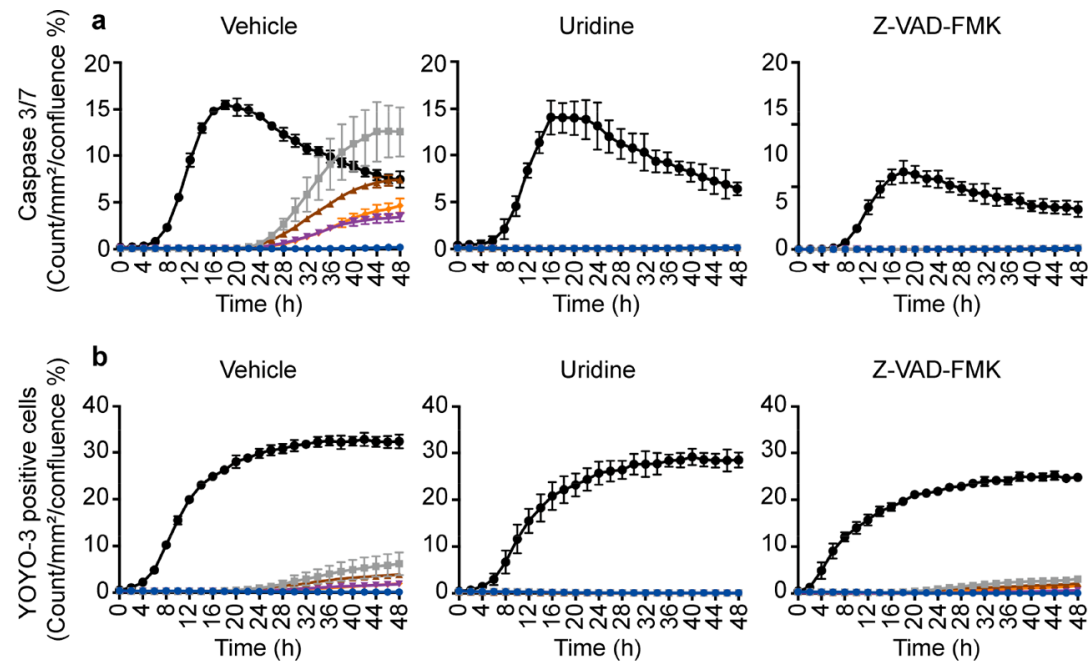

$\rightarrow$ DMSO
$\rightarrow$ Compound $43 \rightarrow$ Compound $45 \rightarrow$ Compound $51 \rightarrow$ BQ

Figure 7. DHODH inhibitors activate caspase 3/7. ARN8 cells were treated with $20 \mathrm{nM}$ of compounds 43, 45, and 51, $250 \mathrm{nM}$ brequinar (BQ), or $1 \mu \mathrm{M}$ staurosporine (STP) for $48 \mathrm{~h}$. Where indicated, the medium was supplemented with $100 \mu \mathrm{M}$ uridine or $20 \mu \mathrm{M}$ Z-VAD-FMK. The effect of the treatments on the (a) caspase 3/7 substrate or (b) YOYO-3 nuclear staining was measured every $2 \mathrm{~h}$ using the IncuCyte S3 system. The caspase $3 / 7$ substrate is activated and emits a green fluorescent signal after cleavage by caspase 3 or 7 and subsequent binding to DNA. YOYO-3 emits a red fluorescent signal after intercalating between DNA base pairs. The number of positive cells per $\mathrm{mm}^{2}$ was normalized to the cell confluence \% in each well. Graphs show the mean values \pm SD of three technical replicates. The experiment is representative of three independent biological replicates.

An increase of $\gamma$-H2AX levels can be due to DNA damage ${ }^{41,42}$ or replication fork stalling, ${ }^{46}$ but it can also be a consequence of the induction of apoptosis. ${ }^{47,48}$ Therefore, we tested whether the increased phosphorylation of $\mathrm{H} 2 \mathrm{AX}$ in response to treatment with the $\mathrm{HZ}$ compounds is due to DNA fragmentation caused by activation of apoptosis. For this purpose, the pan-caspase inhibitor Z-VAD-FMK ${ }^{49}$ was used. As shown in Figure $6 \mathrm{~b}$, the levels of $\gamma-\mathrm{H} 2 \mathrm{AX}$ were reduced considerably in all DHODH inhibitor-treated cells after the addition of Z-VAD-FMK. This pan-caspase inhibitor, however, did not lower the levels of $\gamma$-H2AX in the presence of etoposide. Additionally, cotreatment with staurosporine (STP), a compound that can induce caspase-dependent and caspase-independent apoptosis, ${ }^{50}$ and Z-VAD-FMK resulted in a small decrease of phosphorylated H2AX. These results show that the appearance of $\gamma-\mathrm{H} 2 \mathrm{AX}$ after treatment with DHODH inhibitors correlates with the induction of caspase-dependent apoptosis.

Supporting the notion that DHODH inhibitors cause apoptosis in ARN8 cells, we measured the levels of other apoptosis-related proteins in response to treatment with DHODH inhibitors. As shown in Figure $6 \mathrm{~b}$, the levels of caspase cleaved PARP $^{51}$ increased after treatment with DHODH inhibitors, and the cleavage was prevented by the addition of Z-VAD-FMK.

To confirm the activation of the caspase cascade in DHODH inhibitor-treated cells, we performed live-cell imaging using a caspase- $3 / 7$ substrate that emits a fluorescent signal upon binding to DNA following caspase 3 or 7 cleavage (Figure 7a) and the cell-impermeant nuclear dye YOYO-3 (Figure $7 \mathrm{~b}$ ) that fluoresces upon binding to nucleic acids. All tested compounds increased the signal of the caspase 3/7 substrate, and cotreatment with Z-VAD-FMK led to its reduction. In agreement with the previously discussed results, supplementation with uridine ablated the effect of DHODH inhibitors on the marker for caspase $3 / 7$ activation, while the samples treated with staurosporine were not affected. These results support our hypothesis that inhibition of DHODH induces caspase-dependent apoptosis.

Treatment with DHODH inhibitors increased the fraction of cells positive for YOYO-3 as well, although to a lesser extent than treatment with staurosporine (Figure $7 \mathrm{~b}$ ). Furthermore, the number of YOYO-3 positive cells $/ \mathrm{mm}^{2} /$ confluence $\%$ was lower compared to the caspase 3/7 substrate. Supplementation with uridine prevented the effect of the DHODH inhibitors, and cotreatment with Z-VAD-FMK also reduced the proportion of YOYO-3 positive cells in all samples.

The levels of several proteins located upstream of the caspases were also analyzed by Western blotting. The proapoptotic Bcl family member Bax, a downstream effector of p53, was increased after $24 \mathrm{~h}$ treatment with DHODH inhibitors, while the levels of the antiapoptotic $\mathrm{Bcl}-2$ protein were decreased (Figure S6). The levels of $\mathrm{Bax}$ and $\mathrm{Bcl}-2$ (Figure S6), as well as p53/p-Ser15 p53 (Figure 6b), which are upstream of the effector caspases, were not affected by Z-VADFMK in response to any of the treatments.

\section{CONCLUSION}

Several of the new HZ analogues presented in this study are potent inhibitors of DHODH in an enzymatic assay and are active on cultured cells. Furthermore, the rescue of cell growth/viability by supplementation with high concentrations of uridine for the selected new HZ compounds suggests that the observed effects are indeed due to inhibition of the de novo pyrimidine synthesis pathway. Out of the new HZ00 and HZ05 analogues, compound $\mathbf{5 1}$ is the most favorable one, based on its potency, solubility, and metabolic stability in both HLM and MLM. This makes the compound a suitable candidate for future testing in in vivo pharmacokinetic, toxicity, and efficacy studies. 
Finally, we present evidence suggesting that the appearance of p-Ser15 p53 and $\gamma$-H2AX upon DHODH inhibition does not necessarily indicate activation of the DNA damage response but rather induction of apoptosis. Assessing the potential genotoxicity arising from depletion of pyrimidine ribonucleotide pools is of interest from a mechanistic perspective as well as from a clinical safety perspective.

\section{EXPERIMENTAL SECTION}

Chemistry. Brequinar was purchased from Sigma-Aldrich (no. SML0113), and methyl 6-(([1-(2-fluorophenyl)-4,5,6,7-tetrahydro$1 H$-indazol-4-yl $]$ amino) carbonyl)nicotinate (35) was purchased from Chembridge (no. 34540860). The following starting materials were commercially available or synthesized as described in literature: 1Phenyl-4,5,6,7-tetrahydro- $1 \mathrm{H}$-indazol-4-one (4) was purchased from Enamine. 1-(2-Fluorophenyl)-6,7-dihydro- $1 \mathrm{H}$-indazol-4(5H)-one (5), 1-(2-fluorophenyl)-4,5,6,7-tetrahydro-1 $H$-indazol-4-amine (12), (S)- $\mathrm{N}$-((R)-1-(2-fluorophenyl)-4,5,6,7-tetrahydro-1H-indazol-4-yl)-2methylpropane-2-sulfinamide (17), and (R)-1-(2-fluorophenyl)4,5,6,7-tetrahydro- $1 \mathrm{H}$-indazol-4-amine hydrochloride (21) were synthesized as described in Ladds et al. ${ }^{30}$ 2-Bromo-4,5-dimethylpyridine (25) was synthesized from 3,4-dimethylpyridine as described in T. Kaminski et al. ${ }^{52}$

Additional chemicals and reagents were obtained from commercial suppliers and were used as received unless otherwise stated. Tetrahydrofuran (THF) and dichloromethane (DCM) were obtained dry from solvent purification systems. Flash column chromatography was performed using silica gel $(40-63 \mu \mathrm{m})$, and automated flash chromatography was performed using prepacked silica columns. ${ }^{1} \mathrm{H}$ $\mathrm{NMR}$ and ${ }^{13} \mathrm{C}$ NMR spectra were recorded in $\mathrm{CDCl}_{3}$ (internal standard: $7.26 \mathrm{ppm},{ }^{1} \mathrm{H} ; 77.16 \mathrm{ppm},{ }^{13} \mathrm{C}$ ), DMSO- $d_{6}$ (internal standard: $2.50 \mathrm{ppm},{ }^{1} \mathrm{H} ; 39.52 \mathrm{ppm},{ }^{13} \mathrm{C}$ ), or methanol- $d_{4}$ (internal standard: $3.31 \mathrm{ppm},{ }^{1} \mathrm{H}$; $49.00 \mathrm{ppm},{ }^{13} \mathrm{C}$ ) on 300,400 , or $500 \mathrm{MHz}$ spectrometers. Coupling constants $(J)$ are quoted in hertz $(\mathrm{Hz})$ and are recorded to the nearest $0.1 \mathrm{~Hz}$. The following abbreviations are used: s, singlet; d, doublet; dd, doublet of doublets; t, triplet; m, multiplet; q, quartet; and br, broad.

Analytical RPLC-MS was performed using a HPLC-MS Dionex Ultimate 3000 with a Bruker amaZon SL, under the following conditions: Column, Kinetex $\mathrm{C} 18(2.6 \mu \mathrm{m}, 50 \mathrm{~mm} \times 3.0 \mathrm{~mm})$; mobile phases, $\mathrm{MeCN} /$ water gradients $(0.05 \% \mathrm{HCOOH})$; flow rate, $1.5 \mathrm{~mL} / \mathrm{min}$; detection, UV $(214,254,280 \mathrm{~nm})$, and MS (ESI, pos, neg, or alternate polarity) or an Agilent/HP 1200 system 6110 mass spectrometer with electrospray ionization (ESI+). HPLC-MS methods were the following. Method 1: Waters XBridge C18 3.5 $\mu \mathrm{m}$ column $(3.0 \mathrm{~mm} \times 50 \mathrm{~mm}), 3.5 \mathrm{~min}$ gradient mobile phase $[\mathrm{MeCN}] /\left[10 \mathrm{mM} \mathrm{NH}_{4} \mathrm{HCO}_{3} / \mathrm{H}_{2} \mathrm{O}\right]$.Method 2: MeCN C18 $3.5 \mu \mathrm{m}$ column $(3.0 \mathrm{~mm} \times 50 \mathrm{~mm})$, mobile phase $[0.1 \% \mathrm{TFA} / \mathrm{MeCN}] /$ $\left[0.1 \% \mathrm{TFA} / \mathrm{H}_{2} \mathrm{O}\right]$ on a Water micro mass $\mathrm{ZQ} 2000$ using positive and negative electrospray ionization.

High-resolution molecular masses (HRMS) were determined on a mass spectrometer equipped with an ESI source and a 7-T hybrid linear ion trap (LTQ).

Preparative RP-LC was performed using either a Zorbax SB-C8, a VP 250/21 Nucleodur C-18, HTec, or an Ace C-8 column with a $\mathrm{MeCN} /$ water eluent system with either $0.1 \%$ TFA or $0.05 \% \mathrm{HCOOH}$ as an additive. Chiral Separations were performed using an SFC Waters Investigator system with a Waters 2998 PDA detector. The column temperature was set to $45{ }^{\circ} \mathrm{C}$.

The purity of the tested compounds $\mathbf{2 9 - 5 4}$ is at least $95 \%$ as assessed by HPLC-UV at 214, 254, and $280 \mathrm{~nm}$ or by NMR. Exceptions are stated in the synthesis description.

1-(2-Methylphenyl)-4,5,6,7-tetrahydro- $1 \mathrm{H}$-indazol-4-one (6). The title compound was prepared using the method described by Guo et al. ${ }^{32}$ Yield: $1.11 \mathrm{~g}, 70 \% .{ }^{1} \mathrm{H}$ NMR $\left(400 \mathrm{MHz}, \mathrm{CDCl}_{3}\right): \delta 8.07$ (s, $1 \mathrm{H}), 7.45-7.29(\mathrm{~m}, 3 \mathrm{H}), 7.29-7.25$ (solvent), 7.24 (dd, $J=7.8$, $1.4 \mathrm{~Hz}, 1 \mathrm{H}), 2.64(\mathrm{t}, J=6.2 \mathrm{~Hz}, 2 \mathrm{H}), 2.58-2.50(\mathrm{~m}, 2 \mathrm{H}), 2.21-2.11$ $(\mathrm{m}, 2 \mathrm{H}), 2.11(\mathrm{~s}, 3 \mathrm{H}) . \mathrm{ES}^{+}: m / z 227[\mathrm{M}+\mathrm{H}]^{+}$.
1-(2-Fluoro-5-methylphenyl)-4,5,6,7-tetrahydro- $1 \mathrm{H}$-indazol-4-one (7). The title compound was prepared using the method described by Guo et al. ${ }^{32}$ Yield: $1.07 \mathrm{~g}, 73 \% .{ }^{1} \mathrm{H}$ NMR $(400 \mathrm{MHz}$, $\left.\mathrm{CDCl}_{3}\right): \delta 8.09(\mathrm{~s}, 1 \mathrm{H}), 7.33(\mathrm{dd}, J=7.0,1.9 \mathrm{~Hz}, 1 \mathrm{H}), 7.27-7.21(\mathrm{~m}$, $1 \mathrm{H}), 7.14(\mathrm{dd}, J=10.1,8.5 \mathrm{~Hz}, 1 \mathrm{H}), 2.80(\mathrm{td}, J=6.3,1.4 \mathrm{~Hz}, 2 \mathrm{H})$, $2.55(\mathrm{dd}, J=7.3,5.6 \mathrm{~Hz}, 2 \mathrm{H}), 2.39(\mathrm{~s}, 3 \mathrm{H}), 2.21-2.10(\mathrm{~m}, 2 \mathrm{H}) . \mathrm{ES}^{+}$: $\mathrm{m} / z 245[\mathrm{M}+\mathrm{H}]^{+}$.

1-(3-Methylphenyl)-1,5,6,7-tetrahydro-4H-indazol-4-one (8). The title compound was prepared using the method described by Guo et al. ${ }^{32}$ Yield: $0.405 \mathrm{~g}, 89.4 \% .{ }^{1} \mathrm{H}$ NMR $\left(400 \mathrm{MHz}, \mathrm{CDCl}_{3}\right): \delta$ $8.08(\mathrm{~s}, 1 \mathrm{H}), 7.42-7.36(\mathrm{~m}, 2 \mathrm{H}), 7.30-7.24(\mathrm{~m}, 2 \mathrm{H}), 2.98(\mathrm{t}, J=6.2$ $\mathrm{Hz}, 2 \mathrm{H}), 2.55(\mathrm{~m}, 2 \mathrm{H}), 2.45(\mathrm{~s}, 3 \mathrm{H}), 2.18(\mathrm{~m}, 2 \mathrm{H}) . \mathrm{ES}^{+}: \mathrm{m} / z 227[\mathrm{M}$ $+\mathrm{H}]^{+}$.

1-(2,3-Dimethylphenyl)-4,5,6,7-tetrahydro-1H-indazol-4one (9). The title compound was prepared using the method described by Guo et al. ${ }^{32}$ Yield: $0.425 \mathrm{~g}, 88.4 \% .{ }^{1} \mathrm{H}$ NMR $(400 \mathrm{MHz}$, $\left.\mathrm{CDCl}_{3}\right): \delta 8.07(\mathrm{~s}, 1 \mathrm{H}), 7.29(\mathrm{~d}, J=7.6 \mathrm{~Hz}, 1 \mathrm{H}), 7.21(\mathrm{t}, J=7.6 \mathrm{~Hz}$, $1 \mathrm{H}), 7.09(\mathrm{~d}, J=7.6 \mathrm{~Hz}, 1 \mathrm{H}), 2.62(\mathrm{t}, J=6.0 \mathrm{~Hz}, 2 \mathrm{H}), 2.52-2.55(\mathrm{~m}$, $2 \mathrm{H}), 2.35(\mathrm{~s}, 3 \mathrm{H}), 2.13-2.18(\mathrm{~m}, 2 \mathrm{H}), 1.94(\mathrm{~s}, 3 \mathrm{H}) . \mathrm{ES}^{+}: \mathrm{m} / z 241$ $[\mathrm{M}+\mathrm{H}]^{+}$.

Ethyl 3-(4-Oxo-4,5,6,7-tetrahydro- $1 \mathrm{H}$-indazol-1-yl)benzoate (10). 2-Dimethylaminomethylenecyclohexane-1,3-dione $(0.3344 \mathrm{~g}$, $2.0 \mathrm{mmol})$ and 3-hydrazinylbenzoic acid $(0.3043 \mathrm{~g}, 2.0 \mathrm{mmol})$ were dissolved in methanol $(12.0 \mathrm{~mL})$. Water and $\mathrm{NaOH}(\mathrm{aq}, 1.0 \mathrm{~mL}, 2.0$ $\mathrm{M})$ were added. The reaction mixture was heated at $90^{\circ} \mathrm{C}$ for $2 \mathrm{~h}$ and then concentrated under a vacuum. To the residue were added acetic acid $(12.0 \mathrm{~mL})$ and water $(6.0 \mathrm{~mL})$, and the mixture was heated at $110{ }^{\circ} \mathrm{C}$ for $1.5 \mathrm{~h}$. The solution was concentrated under a vacuum. Ethyl acetate $(20 \mathrm{~mL})$ was added to the residue, and the mixture was washed with brine $(20 \mathrm{~mL})$, dried over $\mathrm{Na}_{2} \mathrm{SO}_{4}$, and concentrated. To the residue were added ethanol $(10 \mathrm{~mL})$ and concentrated sulfuric acid $(0.15 \mathrm{~mL})$. The mixture was refluxed overnight. The solvents were removed under a vacuum, and ethyl acetate $(20 \mathrm{~mL})$ was added to the residue. The mixture was washed with $\mathrm{NaHCO}_{3}$ and brine and was dried over $\mathrm{Na}_{2} \mathrm{SO}_{4}$. The residue was purified by silica gel chromatography (petroleum ether/ethyl acetate, $2: 1$ ) to yield $0.240 \mathrm{~g}$, $42 \% .{ }^{1} \mathrm{H}$ NMR $\left(400 \mathrm{MHz}, \mathrm{CDCl}_{3}\right): \delta 8.15-8.17(\mathrm{~m}, 1 \mathrm{H}), 8.09-8.11$ $(\mathrm{m}, 2 \mathrm{H}), 7.73-7.76(\mathrm{~m}, 1 \mathrm{H}), 7.58-7.62(\mathrm{~m}, 1 \mathrm{H}), 4.41(\mathrm{q}, J=7.1 \mathrm{~Hz}$, $2 \mathrm{H}), 3.01(\mathrm{t}, J=6.2 \mathrm{~Hz}, 2 \mathrm{H}), 2.55-2.58(\mathrm{~m}, 2 \mathrm{H}), 2.16-2.22(\mathrm{~m}$, $2 \mathrm{H}), 1.41(\mathrm{t}, J=7.1 \mathrm{~Hz}, 3 \mathrm{H}) . \mathrm{ES}^{+}: m / z 285[\mathrm{M}+\mathrm{H}]^{+}$.

1-Phenyl-4,5,6,7-tetrahydroindazol-4-amine hydrochloride (11). The compound was synthesized using the method described by Guo et al. ${ }^{32}$ The hydrochloric salt was obtained by treatment with $\mathrm{HCl}$ in EtOH and EtOAc and evaporation to give $141 \mathrm{mg}, 54 \% .{ }^{1} \mathrm{H}$ NMR (400 MHz, DMSO- $\left.d_{6}\right): \delta 8.48($ br s, $3 \mathrm{H}), 7.90(\mathrm{~s}, 1 \mathrm{H}), 7.61-$ $7.48(\mathrm{~m}, 4 \mathrm{H}), 7.45-7.33(\mathrm{~m}, 1 \mathrm{H}), 4.47-4.29(\mathrm{~m}, 1 \mathrm{H}), 2.77(\mathrm{t}, J=$ $5.69 \mathrm{~Hz}, 2 \mathrm{H}), 2.16-1.88(\mathrm{~m}, 2 \mathrm{H}), 1.86-1.67(\mathrm{~m}, 2 \mathrm{H}) . \mathrm{ES}^{+}: \mathrm{m} / z 214$ $[\mathrm{M}+\mathrm{H}]^{+}$.

1-(2-Methylphenyl)-4,5,6,7-tetrahydro-1 $\mathrm{H}$-indazol-4-amine (13). The compound was synthesized using the method described by Guo et al. ${ }^{32}$ to yield the crude product as a solid $(47 \mathrm{mg}, 100 \%) . \mathrm{ES}^{+}$: $\mathrm{m} / z 228[\mathrm{M}+\mathrm{H}]^{+}$.

1-(3-Methylphenyl)-4,5,6,7-tetrahydro- $H$-indazol-4-amine (14). The title compound was synthesized using the method described by Guo et al. ${ }^{32}$ The crude product $(0.504 \mathrm{~g})$ was used without further purification. $\mathrm{ES}^{+}: m / z 228[\mathrm{M}+\mathrm{H}]^{+}$.

1-(2,3-Dimethylphenyl)-4,5,6,7-tetrahydro- $1 \mathrm{H}$-indazol-4amine (15). The title compound was synthesized using the method described by Guo et al. ${ }^{32}$ The crude product $(0.585 \mathrm{~g})$ was used without further purification. $\mathrm{ES}^{+}: m / z 242[\mathrm{M}+\mathrm{H}]^{+}$.

Ethyl 3-(4-Amino-4,5,6,7-tetrahydro-1 $\mathrm{H}$-indazol-1-yl)benzoate (16). The title compound was synthesized using the method described by Guo et al..$^{32}$ by using ethyl 3-(4,5,6,7-tetrahydro4-oxo- $1 \mathrm{H}$-indazol-1-yl)benzoate as a starting material, with the modification that the heating time was $7 \mathrm{~h}$ at $70{ }^{\circ} \mathrm{C}$, to give a crude product $(0.342 \mathrm{~g})$. ES $: m / z 286[\mathrm{M}+\mathrm{H}]^{+}$.

(S)-2-Methyl- $N$-[(4R)-1-(2-methylphenyl)-4,5,6,7-tetrahydro-1 $H$-indazol-4-yl]propane-2-sulfinamide (18). The compound was synthesized according to the method described in Ladds et al. ${ }^{30}$ to give a solid $(1.6 \mathrm{~g}, 70 \%) .{ }^{1} \mathrm{H}$ NMR $\left(400 \mathrm{MHz}, \mathrm{DMSO}-d_{6}\right)$ : $\delta 7.51(\mathrm{~s}, 1 \mathrm{H}), 7.45-7.36(\mathrm{~m}, 2 \mathrm{H}), 7.36-7.24(\mathrm{~m}, 1 \mathrm{H}), 7.21(\mathrm{~m}$, 
$1 \mathrm{H}), 5.40(\mathrm{~d}, J=8.4 \mathrm{~Hz}, 1 \mathrm{H}), 4.40-4.30(\mathrm{~m}, 1 \mathrm{H}), 2.41-2.20(\mathrm{~m}$, $2 \mathrm{H}), 2.07-1.88(\mathrm{~m}, 5 \mathrm{H}), 1.83-1.63(\mathrm{~m}, 2 \mathrm{H}), 1.16(\mathrm{~s}, 9 \mathrm{H}) . \mathrm{ES}^{+}: \mathrm{m} / z$ $332[\mathrm{M}+\mathrm{H}]^{+}$.

(S)- $N$-[(4R)-1-(2-Fluoro-5-methylphenyl)-4,5,6,7-tetrahydro$1 H$-indazol-4-yl]-2-methylpropane-2-sulfinamide (19). The compound was synthesized according to the method described in Ladds et al. ${ }^{30}$ to give the title compound $(0.94 \mathrm{~g}, 61 \%) .{ }^{1} \mathrm{H}$ NMR $\left(400 \mathrm{MHz}, \mathrm{CDCl}_{3}\right): \delta 7.64(\mathrm{~s}, 1 \mathrm{H}), 7.29-7.23(\mathrm{~m}, 1 \mathrm{H}$, overlapping with the solvent signal), 7.21-7.14 $(\mathrm{m}, 1 \mathrm{H}), 7.13-7.05(\mathrm{~m}, 1 \mathrm{H})$, $4.55-4.45(\mathrm{~m}, 1 \mathrm{H}), 3.34(\mathrm{~d}, J=9.5 \mathrm{~Hz}, 1 \mathrm{H}), 2.62-2.42(\mathrm{~m}, 2 \mathrm{H})$, $2.36(\mathrm{~s}, 3 \mathrm{H}), 2.33-2.24(\mathrm{~m}, 1 \mathrm{H}), 2.00-1.73(\mathrm{~m}, 3 \mathrm{H}), 1.26(\mathrm{~s}, 9 \mathrm{H})$. $\mathrm{ES}^{+}: m / z 350[\mathrm{M}+\mathrm{H}]^{+}$.

Propan-2-yl-3-[(4R)-4-([(R)-2-methylpropane-2-sulfinyl]amino)-4,5,6,7-tetrahydro-1H-indazo-1-yl]benzoate (20). The compound was synthesized from 10 using the method described in Ladds et al. ${ }^{30}$ with the modification that $\mathrm{Ti}(\mathrm{O}-\mathrm{i}-\mathrm{Pr})_{4}$ was used instead of $\mathrm{Ti}(\mathrm{OEt})_{4}$, to give the title compound as a solid $(0.70 \mathrm{~g}, 52 \%) .{ }^{1} \mathrm{H}$ NMR (400 MHz, DMSO- $\left.d_{6}\right): \delta 8.07(\mathrm{t}, J=1.8 \mathrm{~Hz}, 1 \mathrm{H}), 7.90-7.95$ $(\mathrm{m}, 1 \mathrm{H}), 7.83(\mathrm{ddd}, J=8.1,2.3,1.0 \mathrm{~Hz}, 1 \mathrm{H}), 7.66(\mathrm{t}, J=7.90 \mathrm{~Hz}$, $1 \mathrm{H}), 7.61(\mathrm{~s}, 1 \mathrm{H}), 5.46(\mathrm{~d}, J=8.7 \mathrm{~Hz}, 1 \mathrm{H}), 5.17(\mathrm{spt}, J=6.3 \mathrm{~Hz}$, $1 \mathrm{H}), 4.29-4.39(\mathrm{~m}, 1 \mathrm{H}), 2.65-2.84(\mathrm{~m}, 2 \mathrm{H}), 1.91-2.08(\mathrm{~m}, 2 \mathrm{H})$, $1.65-1.86(\mathrm{~m}, 2 \mathrm{H}), 1.34(\mathrm{~d}, J=6.2 \mathrm{~Hz}, 6 \mathrm{H}), 1.16(\mathrm{~s}, 9 \mathrm{H}) . \mathrm{ES}^{+}: \mathrm{m} / z$ $404[\mathrm{M}+\mathrm{H}]^{+}$.

(4R)-1-(2-Methylphenyl)-4,5,6,7-tetrahydro-1 $\mathrm{H}$-indazol-4amine (22). Concentrated hydrochloric acid $(4 \mathrm{~mL})$ was added dropwise to a solution of $18(1.11 \mathrm{~g}, 3.32 \mathrm{mmol})$ in methanol (40 $\mathrm{mL}$ ). The mixture was stirred at $\mathrm{rt}$ for $2 \mathrm{~h}$. Saturated aqueous $\mathrm{NaHCO}_{3}$ was added to $\mathrm{pH} 7$, followed by water. The mixture was extracted with DCM. The organic layer was washed with saturated aqueous $\mathrm{NaHCO}_{3}$ and brine. The organic layer was concentrated under a vacuum to afford the title compound $(0.52 \mathrm{~g}$, 68\%), which was used without further purification. $\mathrm{ES}^{+}: m / z 228[\mathrm{M}+\mathrm{H}]^{+}$.

(4R)-1-(2-Fluoro-5-methylphenyl)-4,5,6,7-tetrahydro- $1 \mathrm{H}$-indazol-4-amine (23). Compound $19(300 \mathrm{mg}, 0.858 \mathrm{mmol})$ was dissolved in methanol $(2 \mathrm{~mL})$, and concentrated hydrochloric acid $(196 \mu \mathrm{L}, 2.42 \mathrm{mmol})$ was added. The mixture was stirred at $\mathrm{rt}$ for 30 min. $\mathrm{NaHCO}_{3}$ (sat, aq) and DCM were added. The phases were separated, and the organic phase was washed with $\mathrm{NaHCO}_{3}$ (sat. aq) and brine, dried over $\mathrm{MgSO}_{4}$, and concentrated to give the title compound (171 mg, 81\%). ${ }^{1} \mathrm{H}$ NMR (400 $\mathrm{MHz}, \mathrm{CDCl}_{3}$ ): $\delta 7.69(\mathrm{~s}$, $1 \mathrm{H}), 7.28-7.22(\mathrm{~m}, 1 \mathrm{H}), 7.18-7.12(\mathrm{~m}, 1 \mathrm{H}), 7.07(\mathrm{dd}, J=10.1,8.5$ $\mathrm{Hz}, 1 \mathrm{H}), 4.07-3.98(\mathrm{~m}, 1 \mathrm{H}), 2.60-2.42(\mathrm{~m}, 2 \mathrm{H}), 2.35(\mathrm{~s}, 3 \mathrm{H})$, $2.10-1.88(\mathrm{~m}, 2 \mathrm{H}), 1.80-1.68(\mathrm{~m}, 1 \mathrm{H}), 1.56-1.46(\mathrm{~m}, 1 \mathrm{H}) . \mathrm{ES}^{+}: \mathrm{m} /$ $z 246[\mathrm{M}+\mathrm{H}]^{+}$.

Propan-2-yl-3-[(4R)-4-amino-4,5,6,7-tetrahydro- $1 \mathrm{H}$-indazo1-yl]benzoate (24). Compound $20(172 \mathrm{mg}, 0.341 \mathrm{mmol})$ was dissolved in methanol $(4.5 \mathrm{~mL}$ ), and $\mathrm{HCl}$ (conc. $0.5 \mathrm{~mL}$ ) was added dropwise at $0{ }^{\circ} \mathrm{C}$. The mixture was stirred for $30 \mathrm{~min}$ at $0{ }^{\circ} \mathrm{C}$ and then left at rt over $90 \mathrm{~min}$. The mixture was neutralized with $\mathrm{NaHCO}_{3}$, extracted with EtOAC, and dried $\left(\mathrm{Na}_{2} \mathrm{SO}_{4}\right)$. The solvents were evaporated to give the title compound as an oil ( $85 \mathrm{mg}, 83 \%)$, which was used directly in the next step.

Methyl 4,5-Dimethylpyridine-2-carboxylate (26). Bis(acetato)bis[o-(di-o-tolylphosphino)benzyl]dipalladium(II) $(44 \mathrm{mg}$, $0.047 \mathrm{mmol})$, tri-tert-butylphosphonium tetrafluoroborate $(55 \mathrm{mg}$, $0.19 \mathrm{mmol})$, molybdenumhexacarbonyl $(248 \mathrm{mg}, 0.940 \mathrm{mmol})$, and 2-bromo-4,5-dimethyl-pyridine $(175 \mathrm{mg}, 0.940 \mathrm{mmol})$ were dissolved in methanol $(4 \mathrm{~mL}) .1,8$-Diazabicyclo[5.4.0]undec-7-ene $(0.42 \mathrm{~mL}$, $2.8 \mathrm{mmol}$ ) was added, and the vial was capped and heated in a microwave reactor at $120^{\circ} \mathrm{C}$ for $15 \mathrm{~min}$. After cooling, the reaction mixture was filtered through a silica plug, and the product was eluted with EtOAc. The solution was concentrated, and the title compound was purified by column chromatography on silica eluting with gradients of EtOAc in pentane $(5-50 \%)$ to give the title compound (40 mg, 26\%). ${ }^{1} \mathrm{H}$ NMR (400 MHz, $\left.\mathrm{CDCl}_{3}\right): \delta 8.45$ (s, 1H), 7.92 (s, $1 \mathrm{H}), 4.00(\mathrm{~s}, 3 \mathrm{H}), 2.34(\mathrm{~s}, 3 \mathrm{H}), 2.32(\mathrm{~s}, 3 \mathrm{H}) . \mathrm{ES}^{+}: \mathrm{m} / z 166[\mathrm{M}+$ $\mathrm{H}]^{+}$.

Lithium 4,5-Dimethylpyridine-2-carboxylate (27). Compound 26 (39 mg, $0.24 \mathrm{mmol})$ was dissolved in THF $(0.6 \mathrm{~mL})$ and methanol $(0.6 \mathrm{~mL})$. Lithium hydroxide $(2 \mathrm{M}, 0.24 \mathrm{~mL})$ was added, and the reaction mixture was stirred at $\mathrm{rt}$ overnight. The solvent was removed at reduced pressure, and the residue coevaporated with toluene to dryness. The mixture was used without further purification. $\mathrm{ES}^{+}: m / z 152[\mathrm{M}+\mathrm{H}]^{+}$.

$N$-[(4R)-1-(2-Fluorophenyl)-4,5,6,7-tetrahydro-1 $\mathrm{H}$-indazol4-yl]-5-methylpyridine-2-carboxamide (28). Compound 21 (27 $\mathrm{mg}, 0.101 \mathrm{mmol}$ ), 5-(methyl)pyridine-2-carboxylic acid (14 mg, 0.106 mmol), HATU (42 mg, $0.111 \mathrm{mmol}$ ), and DIPEA (70 $\mu \mathrm{L}, 0.37$ $\mathrm{mmol})$ were dissolved in DCM $(1.5 \mathrm{~mL})$ and DMF $(0.2 \mathrm{~mL})$, and the mixture was stirred at rt overnight. The reaction mixture was purified by column chromatography ( silica column, $12 \mathrm{~g}$ ), eluting with a gradient of EtOAc in hexanes $(20-70 \%)$. The fractions containing product were evaporated and dried under a vacuum to give the title compound (15 mg, 42\%). ${ }^{1} \mathrm{H}$ NMR $\left(400 \mathrm{MHz}\right.$, DMSO- $\left.d_{6}\right): \delta 8.55$ $(\mathrm{d}, J=8.3 \mathrm{~Hz}, 1 \mathrm{H}), 8.49-8.42(\mathrm{~m}, 1 \mathrm{H}), 7.99(\mathrm{~d}, J=8.0 \mathrm{~Hz}, 1 \mathrm{H})$, 7.86-7.78 (m, 1H), 7.60-7.44 (m, 4H), 7.41-7.33 (m, 1H), 5.19$5.10(\mathrm{~m}, 1 \mathrm{H}), 2.38(\mathrm{~s}, 3 \mathrm{H}), 2.05-1.68(\mathrm{~m}, 4 \mathrm{H}) .{ }^{13} \mathrm{C}$ NMR $(101$ $\mathrm{MHz}, \mathrm{DMSO}): \delta 163.4,148.7,147.4,141.1,138.7,138.0,136.5$, $130.5 \mathrm{z}, 128.7,125.2(\mathrm{~d}, J=3.4) 121.6,118.4,116.8(\mathrm{~d}, 20 \mathrm{~Hz}), 41.89$, 29.30, $21.0(\mathrm{~d}, 4.6 \mathrm{~Hz}), 20.0$, 18.0. ESI-HRMS $(\mathrm{m} / z):[\mathrm{M}+\mathrm{H}]^{+}$calcd for $\mathrm{C}_{20} \mathrm{H}_{19} \mathrm{FN}_{4} \mathrm{O}$, 351.1621; found, 351.1614.

(R)- $\mathrm{N}$-(1-(2-Fluorophenyl)-4,5,6,7-tetrahydro-1H-indazol-4yl)-4-methylpicolinamide (29). Compound 21 (18 mg, 0.07 mmol), 4-(methyl)pyridine-2-carboxylic acid $(11 \mathrm{mg}, 0.08 \mathrm{mmol}$ ), HATU $(28 \mathrm{mg}, 0.07 \mathrm{mmol})$ in DMF $(0.1 \mathrm{~mL})$, and DIPEA $(0.05 \mathrm{~mL}$, $0.28 \mathrm{mmol})$ were dissolved in DCM $(1.0 \mathrm{~mL})$ and DMF $(0.1 \mathrm{~mL})$, and the mixture was stirred at rt overnight. The reaction mixture was purified by column chromatography (silica column, $4 \mathrm{~g}$ ) eluting with a gradient of EtOAc in hexanes (20-60\%). The solvents were evaporated to give the title compound as a dry film $(11 \mathrm{mg}, 47 \%$, purity $94 \%) .{ }^{1} \mathrm{H}$ NMR (400 MHz, methanol- $\left.d_{4}\right): \delta 8.46(\mathrm{dd}, J=5.0$, $0.8 \mathrm{~Hz}, 1 \mathrm{H}), 8.03-7.96(\mathrm{~m}, 1 \mathrm{H}), 7.65(\mathrm{~s}, 1 \mathrm{H}), 7.60-7.46(\mathrm{~m}, 2 \mathrm{H})$, $7.43-7.32(\mathrm{~m}, 3 \mathrm{H}), 5.27(\mathrm{t}, J=5.8 \mathrm{~Hz}, 1 \mathrm{H}), 2.69-2.49(\mathrm{~m}, 1 \mathrm{H})$, $2.47(\mathrm{~s}, 3 \mathrm{H}), 2.23-1.83(\mathrm{~m}, 5 \mathrm{H}) .{ }^{13} \mathrm{C}$ NMR $\left(101 \mathrm{MHz}, \mathrm{CDCl}_{3}\right): \delta$ $164.1,156.5(\mathrm{~d}, J=255.8 \mathrm{~Hz}), 149.8,149.0,148.0,141.9,139.6$, $130.1(\mathrm{~d}, J=7.6 \mathrm{~Hz}), 128.8,127.1,124.9(\mathrm{~d}, J=4.0 \mathrm{~Hz}), 123.3$, $118.2,116.8(\mathrm{~d}, J=19.8 \mathrm{~Hz}), 42.5,30.3,21.7(J=4.8 \mathrm{~Hz}), 21.3,20.3$. HRMS $(m / z):[\mathrm{M}+\mathrm{H}]^{+}$calcd for $\mathrm{C}_{20} \mathrm{H}_{19} \mathrm{FN}_{4} \mathrm{O}$, 351.1621; found, 351.1611 .

$\mathrm{N}$-[(4R)-1-(2-Fluorophenyl)-4,5,6,7-tetrahydro- $1 \mathrm{H}$-indazol4-yl]-4-(trifluoromethyl)pyridine-2-carboxamide (30). Compound 21 (230 mg, used as crude, $\max 0.7 \mathrm{mmol}$ ), 4(trifluoromethyl)pyridine-2-carboxylic acid $(149 \mathrm{mg}, 0.78 \mathrm{mmol}$ ), HATU (312 mg, $0.82 \mathrm{mmol})$, and DIPEA $(0.52 \mathrm{~mL}, 2.99 \mathrm{mmol})$ were dissolved in DCM $(4 \mathrm{~mL})$ and DMF $(0.4 \mathrm{~mL})$, and the mixture was stirred at rt overnight. The mixture was washed with brine and dried $\left(\mathrm{MgSO}_{4}\right)$. The residue was purified by column chromatography (silica column, $24 \mathrm{~g}$ ), eluting with a gradient of EtOAc in hexanes $(20-70 \%)$. The fractions containing product were evaporated and dried under a vacuum to give the title compound as a white solid (200 $\mathrm{mg}, 66 \%) .{ }^{1} \mathrm{H}$ NMR (400 MHz, DMSO- $\left.d_{6}\right): \delta 8.92(\mathrm{dd}, J=16.9,6.7$ $\mathrm{Hz}, 2 \mathrm{H}), 8.33-8.27(\mathrm{~m}, 1 \mathrm{H}), 8.07-8.00(\mathrm{~m}, 1 \mathrm{H}), 7.60(\mathrm{~s}, 1 \mathrm{H})$, $7.58-7.43(\mathrm{~m}, 3 \mathrm{H}), 7.42-7.33(\mathrm{~m}, 1 \mathrm{H}), 5.25-5.17(\mathrm{~m}, 1 \mathrm{H}), 2.04-$ $1.83(\mathrm{~m}, 4 \mathrm{H}), 1.83-1.68(\mathrm{~m}, 2 \mathrm{H}) .{ }^{1} \mathrm{H}$ NMR $\left(400 \mathrm{MHz}, \mathrm{CDCl}_{3}\right): \delta$ $8.73(\mathrm{~d}, J=5.0 \mathrm{~Hz}, 1 \mathrm{H}), 8.55-8.45(\mathrm{~m}, 1 \mathrm{H}), 8.18(\mathrm{~d}, J=8.1 \mathrm{~Hz}$, $1 \mathrm{H}), 7.73-7.60(\mathrm{~m}, 2 \mathrm{H}), 7.54-7.35(\mathrm{~m}, 2 \mathrm{H}), 7.32-7.17(\mathrm{~m}, 2 \mathrm{H}$, overlapping with solvent), $5.42-5.27(\mathrm{~m}, 1 \mathrm{H}), 2.60$ (qt, $J=16.5,6.1$ $\mathrm{Hz}, 2 \mathrm{H}), 2.19$ (m, $1 \mathrm{H}), 2.03-1.81(\mathrm{~m}, 3 \mathrm{H}) .{ }^{13} \mathrm{C}$ NMR $(101 \mathrm{MHz}$, $\left.\mathrm{CDCl}_{3}\right): \delta 162.5,156.8(\mathrm{~d}, J=255.5 \mathrm{~Hz}), 151.68,149.3,142.0,140.2$ $\left(\mathrm{q}^{*}, J=34.2 \mathrm{~Hz}\right), 139.4,130.2(\mathrm{~d}, J=7.6 \mathrm{~Hz}), 128.8,127.5(\mathrm{~d}, J=$ $12.0 \mathrm{~Hz}), 125.0(\mathrm{~d}, J=4.0 \mathrm{~Hz}), 122.7\left(\mathrm{q}^{*}, 273.6 \mathrm{~Hz}\right), 121.9(\mathrm{q}, 3.6$ $\mathrm{Hz}), 118.6(\mathrm{q}, 3.6 \mathrm{~Hz}), 117.8,116.8(\mathrm{~d}, 20.0 \mathrm{~Hz}), 42.8,30.3,21.7$ (d, $4.8 \mathrm{~Hz}), 20.3$. HRMS $(\mathrm{m} / z):[\mathrm{M}+\mathrm{H}]^{+}$calcd for $\mathrm{C}_{20} \mathrm{H}_{16} \mathrm{~F}_{4} \mathrm{~N}_{4} \mathrm{O}$, 405.1339; found, 405.1328. *Due to low signal-to-noise, only two out of four peaks in the expected quartet are detected.

4-Chloro- $\mathrm{N}$-[(4R)-1-(2-fluorophenyl)-4,5,6,7-tetrahydro-1 $\mathrm{H}$ indazol-4-yl]pyridine-2-carboxamide (31). Compound 21 (20 $\mathrm{mg}, 0.0750 \mathrm{mmol}$ ), 4-chloropyridine-2-carboxylic acid (12 mg, 0.0750 mmol), T3P (50 wt \% in EtOAc, $93 \mu \mathrm{L}, 0.162 \mathrm{mmol}$ ), and triethylamine $(62 \mu \mathrm{L}, 0.440 \mathrm{mmol})$ were mixed in THF $(0.5 \mathrm{~mL})$. 
The mixture was stirred at $\mathrm{rt}$ for $1 \mathrm{~h}$. The solvents were evaporated, and the residue was purified by preparative HPLC to give the title compound (12 mg, 43\%). ${ }^{1} \mathrm{H}$ NMR ( $400 \mathrm{MHz}$, methanol- $\left.d_{4}\right): \delta 8.54$ (br s, $1 \mathrm{H}), 8.15($ br s, $1 \mathrm{H}), 7.65(\mathrm{~s}, 1 \mathrm{H}), 7.62(\mathrm{~d}, J=3.5 \mathrm{~Hz}, 1 \mathrm{H})$, 7.57-7.52 (m, 1H), 7.51-7.46 (m, 1H), 7.39-7.33 (m, 2H), $5.27(\mathrm{t}$, $J=5.4 \mathrm{~Hz}, 1 \mathrm{H}), 2.67-2.46(\mathrm{~m}, 2 \mathrm{H}), 2.19-1.97(\mathrm{~m}, 2 \mathrm{H}), 1.95-1.77$ $(\mathrm{m}, 2 \mathrm{H})$. HRMS $(\mathrm{m} / \mathrm{z}):[\mathrm{M}+\mathrm{H}]^{+}$calcd for $\mathrm{C}_{19} \mathrm{H}_{16} \mathrm{ClFN}_{4} \mathrm{O}$, 371.1075; found, 371.1084.

4-Bromo- $N$-[(4R)-1-(2-fluorophenyl)-4,5,6,7-tetrahydro- $1 \mathrm{H}$ indazol-4-yl]pyridine-2-carboxamide (32). Compound 21 (20 $\mathrm{mg}, 0.0750 \mathrm{mmol}$ ), 4-bromopyridine-2-carboxylic acid (15 mg, 0.0750 $\mathrm{mmol}$ ), T3P (50 wt \% in EtOAc, $93 \mu \mathrm{L}, 0.162 \mathrm{mmol}$ ), and triethylamine $(62 \mu \mathrm{L}, 0.440 \mathrm{mmol})$ were mixed in THF $(0.5 \mathrm{~mL})$. The mixture was stirred at $\mathrm{rt}$ for $1 \mathrm{~h}$. The solvents were evaporated, and the residue was purified by preparative HPLC to give the title compound (9 mg, 29\%). ${ }^{1} \mathrm{H}$ NMR ( $400 \mathrm{MHz}$, methanol- $\left.d_{4}\right): \delta 8.46$ (br s, $1 \mathrm{H}), 8.31(\mathrm{br} \mathrm{s}, 1 \mathrm{H}), 7.78(\mathrm{~d}, J=3.8 \mathrm{~Hz}, 1 \mathrm{H}), 7.65(\mathrm{~s}, 1 \mathrm{H})$, 7.57-7.52 (m, 1H), 7.52-7.46 (m, 1H), 7.40-7.31 (m, 2H), $5.27(\mathrm{t}$, $J=5.5 \mathrm{~Hz}, 1 \mathrm{H}), 2.67-2.46(\mathrm{~m}, 2 \mathrm{H}), 2.19-1.97(\mathrm{~m}, 2 \mathrm{H}), 1.96-1.82$ $(\mathrm{m}, 2 \mathrm{H})$. HRMS $(m / z):[\mathrm{M}+\mathrm{H}]^{+}$calcd for $\mathrm{C}_{19} \mathrm{H}_{16} \mathrm{BrFN}_{4} \mathrm{O}$, 415.0570; found, 415.0567.

4-Fluoro- $N$-[(4R)-1-(2-fluorophenyl)-4,5,6,7-tetrahydro- $1 \mathrm{H}$ indazol-4-yl]pyridine-2-carboxamide (33). Compound 21 (25 $\mathrm{mg}, 0.093 \mathrm{mmol})$, 4-fluoropyridine-2-carboxylic acid $(16 \mathrm{mg}, 0.11$ mmol), HATU (39 mg, $0.10 \mathrm{mmol}$ ), and DIPEA (0.07 mL, 0.37 $\mathrm{mmol})$ were dissolved in DCM $(1.0 \mathrm{~mL})$ and DMF $(0.1 \mathrm{~mL})$, and the mixture was stirred at $\mathrm{rt}$ overnight. The mixture was purified by column chromatography (silica column, $12 \mathrm{~g}$ ) eluting with a gradient of EtOAc in hexanes $(20-70 \%)$. The solvents were evaporated to give the title compound as a white solid $(28 \mathrm{mg}, 85 \%) .{ }^{1} \mathrm{H}$ NMR (400 $\mathrm{MHz}$, methanol- $\left.d_{4}\right): \delta 8.64(\mathrm{dd}, J=8.0,5.6 \mathrm{~Hz}, 1 \mathrm{H}), 7.90(\mathrm{dd}, J=$ 9.5, $2.4 \mathrm{~Hz}, 1 \mathrm{H}), 7.65(\mathrm{~s}, 1 \mathrm{H}), 7.58-7.45(\mathrm{~m}, 2 \mathrm{H}), 7.42-7.32(\mathrm{~m}$, $3 \mathrm{H}), 5.28(\mathrm{t}, J=5.7 \mathrm{~Hz}, 1 \mathrm{H}), 4.62(\mathrm{~s}, 1 \mathrm{H}), 2.59(\mathrm{~m}, 2 \mathrm{H}), 2.22-1.83$ $(\mathrm{m}, 5 \mathrm{H}) \cdot{ }^{13} \mathrm{C}$ NMR $\left(101 \mathrm{MHz}\right.$, methanol- $\left.d_{4}\right): \delta 171.2(\mathrm{~d}, J=263$ $\mathrm{Hz}), 164.9(\mathrm{~d}, J=3.7 \mathrm{~Hz}), 158.1(\mathrm{~d}, J=251), 154.6(\mathrm{~d}, J=6.6 \mathrm{~Hz})$, 152.7 (d, $J=7.1 \mathrm{~Hz}) 143.6,140.0,132.1$ (d, $7.8 \mathrm{~Hz}), 130.0,128.0$ (d, $12 \mathrm{~Hz}), 126.2$ (d, $4.0 \mathrm{~Hz}), 119.3,117.8(\mathrm{~d}, 20 \mathrm{~Hz}), 115.2(\mathrm{~d}, 17 \mathrm{~Hz})$, $111.1(\mathrm{~d}, 19 \mathrm{~Hz}), 30.8,22.30(\mathrm{~d}, 3.4 \mathrm{~Hz}), 21.3$. HRMS $(\mathrm{m} / \mathrm{z}):[\mathrm{M}+$ $\mathrm{H}]^{+}$calcd for $\mathrm{C}_{19} \mathrm{H}_{16} \mathrm{~F}_{2} \mathrm{~N}_{4} \mathrm{O}$, 355.1370; found, 355.1373.

$\mathrm{N}$-[(4R)-1-(2-Fluorophenyl)-4,5,6,7-tetrahydro- $1 \mathrm{H}$-indazol4-yl]-4,5-dimethylpyridine-2-carboxamide (34). Compound 27 (19 mg, $0.12 \mathrm{mmol}$ ) was suspended in DMF ( $2 \mathrm{~mL})$. HBTU (59 mg, $0.16 \mathrm{mmol}$ ) was added, and the mixture was left to stir at $\mathrm{rt}$ for $1 \mathrm{~h}$. Compound 21 (45 mg, $0.17 \mathrm{mmol}$ ) was added, and the reaction mixture was stirred at $\mathrm{rt}$ overnight. DIPEA $(81 \mu \mathrm{L}, 0.47 \mathrm{mmol})$ and HBTU ( $59 \mathrm{mg}, 0.16 \mathrm{mmol}$ ) were added, and the reaction was stirred at rt overnight. The solvent was removed under a stream of nitrogen, and the product was purified by column chromatography, eluting with gradients of EtOAc in pentane (20-70\%) to give the title compound (34 mg, 79\%, purity 90\%), yield over two steps from $26 .{ }^{1} \mathrm{H}$ NMR $\left(400 \mathrm{MHz}, \mathrm{CDCl}_{3}\right): \delta 8.22(\mathrm{~s}, 1 \mathrm{H}), 8.18(\mathrm{~d}, J=8.2 \mathrm{~Hz}, 1 \mathrm{H}), 8.02(\mathrm{~s}$, $1 \mathrm{H}), 7.68(\mathrm{~s}, 1 \mathrm{H}), 7.47(\mathrm{td}, J=7.7,1.8 \mathrm{~Hz}, 1 \mathrm{H}), 7.44-7.36(\mathrm{~m}, 1 \mathrm{H})$, $7.29-7.20(\mathrm{~m}, 2 \mathrm{H}$, overlapping with the solvent peak $), 5.39-5.28(\mathrm{~m}$, $1 \mathrm{H}), 2.68-2.48(\mathrm{~m}, 2 \mathrm{H}), 2.35(\mathrm{~s}, 3 \mathrm{H}), 2.30(\mathrm{~s}, 3 \mathrm{H}), 2.23-2.09(\mathrm{~m}$, $1 \mathrm{H}), 2.02-1.81(\mathrm{~m}, 3 \mathrm{H}) .{ }^{13} \mathrm{C}$ NMR $\left(101 \mathrm{MHz}, \mathrm{CDCl}_{3}\right): \delta 164.3$, $156.4(\mathrm{~d}, J=251 \mathrm{~Hz}), 148.6,147.9,147.3,141.8,139.6,135.5,130.0$ $(\mathrm{d}, J=7.9 \mathrm{~Hz}), 128.7,127.5(\mathrm{~d}, J=12 \mathrm{~Hz}), 124.9(\mathrm{~d}, J=3.8 \mathrm{~Hz})$, $123.3,118.3,116.8(\mathrm{~d}, J=20 \mathrm{~Hz}), 42.4,30.3,21.7(\mathrm{~d}, J=4.7 \mathrm{~Hz})$, 20.3, 19.5, 16.7. HRMS $(m / z):[\mathrm{M}+\mathrm{H}]^{+}$calcd for $\mathrm{C}_{21} \mathrm{H}_{21} \mathrm{FN}_{4} \mathrm{O}$, 365.1778; found, 365.1780 .

$\mathrm{N}$-[(4R)-1-(2-Fluorophenyl)-4,5,6,7-tetrahydro-1 $\mathrm{H}$-indazol4-yl]pyrimidine-2-carboxamide (36). Compound 21 (40 mg, 0.15 mmol), pyrimidine-2-carboxylic acid ( $27 \mathrm{mg}, 0.16 \mathrm{mmol})$, HATU (62 $\mathrm{mg}, 0.16 \mathrm{mmol})$, and DIPEA $(78 \mu \mathrm{L}, 0.45 \mathrm{mmol})$ were dissolved in DCM $(1.5 \mathrm{~mL})$ and DMF $(0.2 \mathrm{~mL})$, and the mixture was stirred at $\mathrm{rt}$ overnight. The solvents were removed at reduced pressure, and the residue was purified by column chromatography (silica column, $12 \mathrm{~g}$ ), first eluting with a gradient of EtOAc in hexanes (20-80\%), followed by a gradient of $\mathrm{MeOH}$ in DCM (2-10\%). Fractions were pooled and evaporated. The residue was dissolved in DCM, and the organic phase was washed with sat $\mathrm{NH}_{4} \mathrm{Cl}$. The organic phase was evaporated to give the title compound (6 mg, 12\%). ${ }^{1} \mathrm{H}$ NMR (400 $\mathrm{MHz}$, $\left.\mathrm{CDCl}_{3}\right): \delta 8.89(\mathrm{~d}, J=4.9 \mathrm{~Hz}, 2 \mathrm{H}), 8.22(\mathrm{~d}, J=8.1 \mathrm{~Hz}, 1 \mathrm{H}), 7.71(\mathrm{~s}$, $1 \mathrm{H}), 7.55-7.36(\mathrm{~m}, 3 \mathrm{H}), 7.32-7.19(\mathrm{~m}, 2 \mathrm{H}$, overlapping with solvent peak), 5.48-5.37 (m, 1H), 2.70-2.47 (m, 2H), 2.27-2.11 (m, $1 \mathrm{H})$, $2.02-1.80(\mathrm{~m}, 3 \mathrm{H}) .{ }^{13} \mathrm{C}$ NMR $\left(101 \mathrm{MHz}, \mathrm{CDCl}_{3}\right): \delta 161.7,157.9$, $157.6,156.8(\mathrm{~d}, J=252 \mathrm{~Hz}), 142.0,139.5,130.2(\mathrm{~d}, J=7.7 \mathrm{~Hz})$, 128.7, $127.5(\mathrm{~d}, J=11.7 \mathrm{~Hz}), 124.9(\mathrm{~d}, J=4.0 \mathrm{~Hz}), 122.7,117.8$, $116.8(\mathrm{~d}, J=20 \mathrm{~Hz}), 43.0,30.2,21.7(\mathrm{~d}, J=4.8 \mathrm{~Hz}), 20.3$. HRMS $(\mathrm{m} / z):[\mathrm{M}+\mathrm{H}]^{+}$calcd for $\mathrm{C}_{18} \mathrm{H}_{16} \mathrm{FN}_{5} \mathrm{O}$, 338.1417; found, 338.1412.

$\mathrm{N}$-[1-(2-Fluorophenyl)-4,5,6,7-tetrahydro- $1 \mathrm{H}$-indazol-4-yl]benzamide (37). To a mixture of $12(10 \mathrm{mg}, 0.0432 \mathrm{mmol})$, benzoic acid (11 mg, $0.0868 \mathrm{mmol})$, and DIPEA $(22 \mu \mathrm{L}, 0.13 \mathrm{mmol})$ in DCM $(2 \mathrm{~mL})$ was added HATU $(18 \mathrm{mg}, 0.0476 \mathrm{mmol})$, and the reaction was stirred at $\mathrm{rt}$ for $16 \mathrm{~h}$. The organic layer was washed with brine (3 $\times 5 \mathrm{~mL})$ and concentrated. The residue was dissolved in $\mathrm{MeOH}(1$ $\mathrm{mL}$ ) and purified by HPLC. Fractions were pooled and extracted with DCM to give the title compound (4 mg, 28\%). ${ }^{1} \mathrm{H} \mathrm{NMR} \mathrm{(400} \mathrm{MHz,}$ $\left.\mathrm{CDCl}_{3}\right): \delta 7.84-7.77(\mathrm{~m}, 2 \mathrm{H}), 7.70(\mathrm{~s}, 1 \mathrm{H}), 7.56-7.37(\mathrm{~m}, 5 \mathrm{H})$, $7.32-7.20(\mathrm{~m}, 2 \mathrm{H}), 6.29(\mathrm{~d}, J=7.8 \mathrm{~Hz}, 1 \mathrm{H}), 5.41-5.32(\mathrm{~m}, 1 \mathrm{H})$, $2.58(\mathrm{~m}, 2 \mathrm{H}), 2.22-2.12(\mathrm{~m}, 1 \mathrm{H}), 1.91(\mathrm{~m}, 3 \mathrm{H})$. HRMS $(\mathrm{m} / \mathrm{z}):[\mathrm{M}$ $+\mathrm{H}]^{+}$calcd for $\mathrm{C}_{20} \mathrm{H}_{18} \mathrm{FN}_{3} \mathrm{O}$, 336.1512; found, 336.1526.

4-Methyl- $N$-[(4R)-1-(2-methylphenyl)-4, 5,6,7-tetrahydro$1 \mathrm{H}$-indazol-4-yl]pyridine-2-carboxamide (38). Compound 22 $(30 \mathrm{mg}, 0.13 \mathrm{mmol})$, 4-methylpyridine-2-carboxylic acid $(19 \mathrm{mg}$, $0.14 \mathrm{mmol})$, HATU ( $55 \mathrm{mg}, 0.145 \mathrm{mmol})$, and DIPEA (69 $\mu \mathrm{L}, 0.40$ $\mathrm{mmol})$ were dissolved in DCM $(2 \mathrm{~mL})$ and DMF $(0.2 \mathrm{~mL})$, and the mixture was stirred at $\mathrm{rt}$ for $4 \mathrm{~h}$. Water $(1 \mathrm{~mL})$ was added, and the phases were separated. The aqueous phase was extracted with DCM $(2 \times 1 \mathrm{~mL})$. The organic phases were combined and concentrated. The residue was dissolved in $\mathrm{MeCN}(0.5 \mathrm{~mL})$ and water $(0.5 \mathrm{~mL})$. The mixture was purified by preparative HPLC. The solvent was evaporated to give the title compound $(12 \mathrm{mg}, 25 \%)$ as a dry film. ${ }^{1} \mathrm{H}$ $\operatorname{NMR}\left(400 \mathrm{MHz}, \mathrm{CDCl}_{3}\right): \delta 8.39(\mathrm{dd}, J=5.0,0.7 \mathrm{~Hz}, 1 \mathrm{H}), 8.24(\mathrm{dd}$, $J=16.0,8.3 \mathrm{~Hz}, 1 \mathrm{H}), 8.09(\mathrm{dt}, J=1.8,0.7 \mathrm{~Hz}, 1 \mathrm{H}), 7.64(\mathrm{~s}, 1 \mathrm{H})$, 7.38-7.13 (m, 5H, overlapping with solvent signal), 5.38-5.30 (m, $1 \mathrm{H}), 2.53-2.31(\mathrm{~m}, 5 \mathrm{H}), 2.22-2.11(\mathrm{~m}, 1 \mathrm{H}), 2.09(\mathrm{~s}, 3 \mathrm{H}), 2.07-$ $1.81(\mathrm{~m}, 3 \mathrm{H}) .{ }^{13} \mathrm{C}$ NMR $\left(101 \mathrm{MHz}, \mathrm{CDCl}_{3}\right): \delta 164.2,149.9,149.0$, $148.1,140.8,138.4,138.0,136.1,131.2,129.2,127.5,127.1,126.6$, $123.4,117.4,42.7,30.5,21.8,21.3,20.4,17.6$. HRMS $(m / z):[\mathrm{M}+$ $\mathrm{H}]^{+}$calcd for $\mathrm{C}_{21} \mathrm{H}_{22} \mathrm{~N}_{4} \mathrm{O}$, 347.1872; found, 347.1880.

$\mathrm{N}$-[(4R)-1-(2-Fluoro-5-methylphenyl)-4,5,6,7-tetrahydro- $1 \mathrm{H}$ indazol-4-yl]-4-methylpyridine-2-carboxamide (39). 4-Methylpicolinic acid (22 mg, $0.15 \mathrm{mmol})$, HATU (70 mg, $0.18 \mathrm{mmol}), 23$ (35 mg, $0.14 \mathrm{mmol}$ ), and DIPEA (50 $\mu \mathrm{L}, 0.29 \mathrm{mmol}$ ) were dissolved in DCM $(1.5 \mathrm{~mL})$ and DMF $(0.3 \mathrm{~mL})$, and the solution was stirred at rt overnight. The reaction mixture was concentrated, and the mixture was purified by column chromatography eluting with a gradient of EtOAc in hexanes $(20-70 \%)$ to give the title compound $(22 \mathrm{mg}$, $40 \%$, purity $93 \%) .{ }^{1} \mathrm{H}$ NMR $\left(400 \mathrm{MHz}, \mathrm{CDCl}_{3}\right): \delta 8.37$ (d, $J=5.4$ $\mathrm{Hz}, 1 \mathrm{H}), 8.23(\mathrm{~d}, J=8.4 \mathrm{~Hz}, 1 \mathrm{H}), 8.11-8.06(\mathrm{~m}, 1 \mathrm{H}), 7.67(\mathrm{~s}, 1 \mathrm{H})$, 7.28 (dd, $J=7.3,2.1 \mathrm{~Hz}, 1 \mathrm{H}$, overlapping with the solvent peak), 7.23 $(\mathrm{ddd}, J=4.9,1.8,0.8 \mathrm{~Hz}, 1 \mathrm{H}), 7.21-7.15(\mathrm{~m}, 1 \mathrm{H}), 7.10(\mathrm{dd}, J=10.1$, $8.4 \mathrm{~Hz}, 1 \mathrm{H}), 5.40-5.29(\mathrm{~m}, 1 \mathrm{H}), 2.69-2.48(\mathrm{~m}, 2 \mathrm{H}), 2.45(\mathrm{~s}, 3 \mathrm{H})$, $2.37(\mathrm{~s}, 3 \mathrm{H}), 2.24-2.09(\mathrm{~m}, 1 \mathrm{H}), 2.02-1.80(\mathrm{~m}, 3 \mathrm{H}) .{ }^{13} \mathrm{C} \mathrm{NMR}(101$ $\left.\mathrm{MHz}, \mathrm{CDCl}_{3}\right): \delta 164.1,154.4(\mathrm{~d}, J=249 \mathrm{~Hz}), 149.8,149.0,148.0$, $141.8,139.4,134.8$ (d, $J=3.9 \mathrm{~Hz}), 130.4(\mathrm{~d}, J=7.6 \mathrm{~Hz}), 129.0$, 127.1, 123.3, 118.1, 116.3 (d, $J=20 \mathrm{~Hz}), 42.5,30.3,21.7$ (d, $J=4.8$ $\mathrm{Hz}), 21.3,20.7,20.3$. HRMS $(m / z):[\mathrm{M}+\mathrm{H}]^{+}$calcd for $\mathrm{C}_{21} \mathrm{H}_{21} \mathrm{FN}_{4} \mathrm{O}$, 365.1778; found, 365.1780.

$\mathrm{N}$-[(4R)-1-(2-Fluoro-5-methylphenyl)-4,5,6,7-tetrahydro-1 $\mathrm{H}$ indazol-4-yl]-4-(trifluoromethyl)pyridine-2-carboxamide (40). 4-(Trifluoromethyl)picolinic acid (30 mg, $0.15 \mathrm{mmol})$, HATU (60 $\mathrm{mg}, 0.16 \mathrm{mmol}), 23$ (35 mg, $0.14 \mathrm{mmol})$, and DIPEA (50 $\mu \mathrm{L}, 0.29$ $\mathrm{mmol})$ were mixed in DCM $(1.5 \mathrm{~mL})$ and DMF $(0.2 \mathrm{~mL})$, and the mixture was stirred at $\mathrm{rt}$ overnight. The mixture was purified by column chromatography, eluting with a gradient of EtOAc in hexanes $(20-70 \%)$ to give the title compound $(22 \mathrm{mg}, 37 \%) .{ }^{1} \mathrm{H}$ NMR $(400$ $\left.\mathrm{MHz}, \mathrm{CDCl}_{3}\right): \delta 8.73(\mathrm{~d}, J=5.0 \mathrm{~Hz}, 1 \mathrm{H}), 8.50(\mathrm{~s}, 1 \mathrm{H}), 8.18(\mathrm{~d}, J=$ $8.0 \mathrm{~Hz}, 1 \mathrm{H}), 7.71-7.62(\mathrm{~m}, 2 \mathrm{H}), 7.28(\mathrm{dd}, J=7.2,2.0 \mathrm{~Hz}, 1 \mathrm{H})$, 
$7.22-7.16(\mathrm{~m}, 1 \mathrm{H}), 7.11(\mathrm{dd}, J=10.0,8.5 \mathrm{~Hz}, 1 \mathrm{H}), 5.42-5.30(\mathrm{~m}$, $1 \mathrm{H}), 2.71-2.50(\mathrm{~m}, 2 \mathrm{H}), 2.37(\mathrm{~s}, 3 \mathrm{H}), 2.26-2.11(\mathrm{~m}, 1 \mathrm{H}), 2.01-$ $1.81(\mathrm{~m}, 3 \mathrm{H})$. HRMS $(\mathrm{m} / z):[\mathrm{M}+\mathrm{H}]^{+}$calcd for $\mathrm{C}_{21} \mathrm{H}_{18} \mathrm{~F}_{4} \mathrm{~N}_{4} \mathrm{O}$, 419.1495; found, 419.1502 .

$\mathrm{N}$-[(4R)-1-(2-Fluorophenyl)-4,5,6,7-tetrahydro- $1 \mathrm{H}$-indazol4-yl]-4,5,6,7-tetrahydro-1,2-benzoxazole-3-carboxamide (41). Propylphosphonic anhydride solution $(59 \mu \mathrm{L}, 0.103 \mathrm{mmol})$ was added to a slurry of $21(13 \mathrm{mg}, 0.050 \mathrm{mmol}), 4,5,6,7$-tetrahydro-1,2benzoxazole-3-carboxylic acid ( $8 \mathrm{mg}, 0.050 \mathrm{mmol})$, and triethylamine $(29 \mu \mathrm{L}, 0.21 \mathrm{mmol})$ in THF. The mixture was stirred at $\mathrm{rt}$ for $2 \mathrm{~h}$. The reaction mixture was chromatographed through a short silica column eluted with heptanes/EtOAc 1:1 to give the title compound (5 mg, 53\%). ${ }^{1} \mathrm{H}$ NMR (400 MHz, methanol- $\left.d_{4}\right): \delta 7.65(\mathrm{~s}, 1 \mathrm{H})$, 7.57-7.50 (m, 1H), 7.50-7.44 (m, 1H), 7.39-7.32 (m, 2H), 5.27$5.21(\mathrm{~m}, 1 \mathrm{H}), 2.76-2.70(\mathrm{~m}, 2 \mathrm{H}), 2.67(\mathrm{td}, J=6.00,1.20 \mathrm{~Hz}, 2 \mathrm{H})$, $2.63-2.47(\mathrm{~m}, 2 \mathrm{H}), 2.12-1.97(\mathrm{~m}, 2 \mathrm{H}), 1.93-1.83(\mathrm{~m}, 4 \mathrm{H}), 1.82-$ $1.74(\mathrm{~m}, 2 \mathrm{H})$. HRMS $(\mathrm{m} / z):[\mathrm{M}+\mathrm{H}]^{+}$calcd for $\mathrm{C}_{21} \mathrm{H}_{21} \mathrm{FN}_{4} \mathrm{O}_{2}$, 381.1743; found, 381.1743 .

$\mathrm{N}$-[(4S)-1-(2-Fluorophenyl)-4,5,6,7-tetrahydro-1 H-indazol-4yl]-4,5,6,7-tetrahydro-1,2-benzoxazole-3-carboxamide (42). Chembridge compound no. 91442433 containing one major pair of enantiomers and one minor pair of enantiomers (38 mg) was dissolved in methanol $(1.5 \mathrm{~mL})$ and purified by SFC, injecting $20 \mu \mathrm{L} /$ run in stacked injections on a Chiral Cellulose column SB (YMC), $250 \times 10 \mathrm{~mm}$ eluting with $\mathrm{CO}_{2}, 20 \%$ methanol, $15 \mathrm{~mL} / \mathrm{min}$. The third eluting peak $\left(t_{\mathrm{R}}=8.5 \mathrm{~min}\right)$ was collected, and the solvents evaporated to give the title compound $(0.9 \mathrm{mg}$, purity $90 \%) .{ }^{1} \mathrm{H}$ NMR $\left(400 \mathrm{MHz}, \mathrm{CDCl}_{3}\right): \delta 7.66(\mathrm{~s}, 1 \mathrm{H}), 7.57-7.46(\mathrm{~m}, 2 \mathrm{H}), 7.39-7.36$ $(\mathrm{m}, 1 \mathrm{H}), 7.35(\mathrm{~d}, J=7.6 \mathrm{~Hz}, 1 \mathrm{H}), 5.26-5.23(\mathrm{~m}, 1 \mathrm{H}) 2.76-2.72(\mathrm{~m}$, $2 \mathrm{H}), 2.70-2.66(\mathrm{~m}, 2 \mathrm{H}), 2.64-2.49(\mathrm{~m}, 2 \mathrm{H}), 2.14-1.99(\mathrm{~m}, 2 \mathrm{H})$, $1.93-1.77(\mathrm{~m}, 6 \mathrm{H}) . \mathrm{ES}^{+}: \mathrm{m} / z 381[\mathrm{M}+\mathrm{H}]^{+}$.

$\mathrm{N}$-[1-(2-Methylphenyl)-4,5,6,7-tetrahydro- $\mathrm{H}$-indazol-4-yl]4,5,6,7-tetrahydro-1,2-benzoxazole-3-carboxamide (43). To a solution of $13(47 \mathrm{mg}, 0.206 \mathrm{mmol})$ and HBTU $(281 \mathrm{mg}, 0.741$ $\mathrm{mmol}$ ) in DMSO (1.2 mL) were added 4,5,6,7-tetrahydro-1,2benzoxazole-3-carboxylic acid $(34 \mathrm{mg}, 0.206 \mathrm{mmol})$ and triethylamine (103 $\mu \mathrm{L}, 0.741 \mathrm{mmol}$ ). The mixture was stirred at $\mathrm{rt}$ for $20 \mathrm{~h}$. The mixture was purified by preparative HPLC to give the title compound as a solid $(10 \mathrm{mg}, 13 \%) .{ }^{1} \mathrm{H}$ NMR $\left(400 \mathrm{MHz}, \mathrm{CDCl}_{3}\right): \delta 7.60(\mathrm{~s}$, $1 \mathrm{H}), 7.43-7.39(\mathrm{~m}, 2 \mathrm{H}), 7.34(\mathrm{~m}, 1 \mathrm{H}), 7.24(\mathrm{~m}, 1 \mathrm{H}), 5.25(\mathrm{~m}, 1 \mathrm{H})$, $2.76-2.72(\mathrm{~m}, 2 \mathrm{H}), 2.70-2.66(\mathrm{~m}, 2 \mathrm{H}), 2.50-2.34(\mathrm{~m}, 2 \mathrm{H}), 2.13-$ $1.99(\mathrm{~m}, 2 \mathrm{H}), 2.06(\mathrm{~s}, 3 \mathrm{H}), 1.93-1.77(\mathrm{~m}, 6 \mathrm{H})$. HRMS $(\mathrm{m} / \mathrm{z}):[\mathrm{M}+$ $\mathrm{H}]^{+}$calcd for $\mathrm{C}_{22} \mathrm{H}_{24} \mathrm{~N}_{4} \mathrm{O}_{2}, 377.1978$; found, 377.1982.

$\mathrm{N}$-[1-(3-Methylphenyl)-4,5,6,7-tetrahydro- $1 \mathrm{H}$-indazol-4-yl]4,5,6,7-tetrahydro-1,2-benzoxazole-3-carboxamide (44). Compound 14 (crude, max $0.596 \mathrm{mmol}$ ), 4,5,6,7-tetrahydrobenzo[d]isoxazole-3-carboxylic acid $(99.6 \mathrm{mg}, 0.596 \mathrm{mmol})$, and TBTU (211 $\mathrm{mg}, 0.655 \mathrm{mmol}$ ) were dissolved in dry DMF $(4.0 \mathrm{~mL})$, and triethylamine $(0.166 \mathrm{~mL})$ was added. The reaction mixture was stirred at $\mathrm{rt}$ for $20 \mathrm{~h}$. The mixture was purified with preparative HPLC to give the title compound $(0.123 \mathrm{~g}, 55 \%) .{ }^{1} \mathrm{H} \mathrm{NMR}\left(400 \mathrm{MHz}, \mathrm{CDCl}_{3}\right): \delta$ $7.66(\mathrm{~s}, 1 \mathrm{H}), 7.36-7.32(\mathrm{~m}, 2 \mathrm{H}), 7.24(\mathrm{br}, 1 \mathrm{H}), 7.17(\mathrm{~m}, 1 \mathrm{H}), 6.96$ $(\mathrm{d}, J=7.9 \mathrm{~Hz}, 1 \mathrm{H}), 5.30(\mathrm{~m}, 1 \mathrm{H}), 2.82-2.67(\mathrm{~m}, 6 \mathrm{H}), 2.42(\mathrm{~s}, 3 \mathrm{H})$, 2.15-2.09 (m, 1H), 1.97-1.85 (m, 5H), $1.81-1.75(\mathrm{~m}, 2 \mathrm{H}) .{ }^{13} \mathrm{C}$ NMR $\left(101 \mathrm{MHz}, \mathrm{CDCl}_{3}\right): \delta 170.6,159.6,155.2,140.0,139.6,139.3$, $138.3,129.1,128.4,124.4,120.6,118.2,113.8,42.3,29.9,23.3,22.9$, 22.4, 22.0, 21.5, 20.3. HRMS (m/z): $[\mathrm{M}+\mathrm{H}]^{+}$calcd for $\mathrm{C}_{22} \mathrm{H}_{24} \mathrm{~N}_{4} \mathrm{O}_{2}$, 377.1978; found, 377.1981.

$\mathrm{N}$-[1-(2,3-Dimethylphenyl)-4,5,6,7-tetrahydro- $1 \mathrm{H}$-indazol-4yl]-4,5,6,7-tetrahydro-1,2-benzoxazole-3-carboxamide (45). The title compound was synthesized using the method described for 44 , starting from intermediate $\mathbf{1 5}$, to give the title compound ( 92 $\mathrm{mg}, 40 \%) .{ }^{1} \mathrm{H}$ NMR $\left(400 \mathrm{MHz}, \mathrm{CDCl}_{3}\right): \delta 7.60(\mathrm{~s}, 1 \mathrm{H}), 7.20(\mathrm{~d}, J=$ $7.5 \mathrm{~Hz}, 1 \mathrm{H}), 7.16(\mathrm{t}, J=7.5 \mathrm{~Hz}, 1 \mathrm{H}), 7.05(\mathrm{~d}, J=7.5 \mathrm{~Hz}, 1 \mathrm{H}), 6.98$ $(\mathrm{d}, J=7.8 \mathrm{~Hz}, 1 \mathrm{H}), 5.32-5.27(\mathrm{~m}, 1 \mathrm{H}), 2.77-2.70(\mathrm{~m}, 4 \mathrm{H}), 2.42-$ $2.34(\mathrm{~m}, 2 \mathrm{H}), 2.32(\mathrm{~s}, 3 \mathrm{H}), 2.11-2.04(\mathrm{~m}, 1 \mathrm{H}), 1.91(\mathrm{~s}, 3 \mathrm{H}), 1.89-$ $1.81(\mathrm{~m}, 5 \mathrm{H}), 1.79-1.73(\mathrm{~m}, 2 \mathrm{H}) .{ }^{13} \mathrm{C}$ NMR $\left(101 \mathrm{MHz}, \mathrm{CDCl}_{3}\right): \delta$ $170.6,159.6,155.3,141.3,138.7,137.5,134.7,130.8,126.1,125.2$, $116.6,113.8,42.4,30.2,22.9,22.4,22.0,21.7,20.4,20.3,19.9,14.3$.
HRMS $(m / z):[M+H]^{+}$calcd for $\mathrm{C}_{23} \mathrm{H}_{27} \mathrm{~N}_{4} \mathrm{O}_{2}$, 391.2134; found, 391.2124

(R)-N-(1-(2-Methylphenyl)-4,5,6,7-tetrahydro-1H-indazol-4yl)-4,5,6,7-tetrahydrobenzo[d] isoxazole-3-carboxamide (46). To $22(27 \mathrm{mg}, 0.12 \mathrm{mmol})$ and 4,5,6,7-tetrahydrobenzo[d]isoxazole-3-carboxylic acid $(19.9 \mathrm{mg}, 0.12 \mathrm{mmol})$ in THF $(1.5 \mathrm{~mL})$ were added DIPEA $(0.1 \mathrm{~mL}, 0.59 \mathrm{mmol})$ and 1-propanephosphonic acid cyclic anhydride ( $50 \mathrm{wt} \%$ in EtOAc, $0.14 \mathrm{~mL}, 0.24 \mathrm{mmol}$ ). The reaction mixture was stirred at $\mathrm{rt}$ for $1 \mathrm{~h}$. DIPEA $(0.04 \mathrm{~mL}, 0.24$ $\mathrm{mmol}$ ) and 1-propanephosphonic acid cyclic anhydride (50 wt \% in EtOAc, $0.04 \mathrm{~mL}, 0.06 \mathrm{mmol}$ ) were added, and the reaction mixture was stirred overnight. The solvents were evaporated, and the residue was purified by HPLC to give the title compound ( $38 \mathrm{mg}, 84 \%) .{ }^{1} \mathrm{H}$ NMR $\left(400 \mathrm{MHz}\right.$, methanol- $\left.d_{4}\right): \delta 7.67(\mathrm{~s}, 1 \mathrm{H}), 7.46-7.39(\mathrm{~m}, 2 \mathrm{H})$, $7.37-7.33(\mathrm{~m}, 1 \mathrm{H}), 7.26(\mathrm{~d}, J=7.5 \mathrm{~Hz}), 5.25 \mathrm{~Hz}(\mathrm{t}, J=7.0 \mathrm{~Hz}, 1 \mathrm{H})$, $2.77-2.65(\mathrm{~m}, 4 \mathrm{H}), 2.51-2.36(\mathrm{~m}, 2 \mathrm{H}), 2.14-1.99(\mathrm{~m}, 5 \mathrm{H}), 1.93-$ $1.76(\mathrm{~m}, 6 \mathrm{H}) .{ }^{13} \mathrm{C}$ NMR $\left(126 \mathrm{MHz}, \mathrm{CDCl}_{3}\right): \delta 170.7,159.7,155.2$, 141.6, 137.5, 137.4, 136.1, 131.4, 129.8, 127.6, 126.8, 117.0, 113.8, $42.3,30.1,22.9,22.4,22.00,21.6,20.3,20.0,17.5 . \mathrm{ES}^{+}: \mathrm{m} / z 377[\mathrm{M}+$ $\mathrm{H}]^{+}$. HRMS $(m / z):[M+H]^{+}$calcd for $\mathrm{C}_{22} \mathrm{H}_{25} \mathrm{~N}_{4} \mathrm{O}_{2}, 377.1978$; found, 377.1979.

$\mathrm{N}$-[(4R)-1-(2-Methylphenyl)-4,5,6,7-tetrahydro- $1 \mathrm{H}$-indazol4-yl]-4,5,6,7-tetrahydro-2,1-benzoxazole-3-carboxamide (47). To a mixture of $22(40 \mathrm{mg}, 0.18 \mathrm{mmol}), 4,5,6,7$-tetrahydrobenzo[c] isoxazole-3-carboxylic acid ( $59 \mathrm{mg}, 0.35 \mathrm{mmol}$ ), and DIPEA (90 $\mu \mathrm{L}, 0.53 \mathrm{mmol})$ in DCM $(2 \mathrm{~mL})$ was added HATU $(74 \mathrm{mg}, 0.19$ $\mathrm{mmol}$ ), and the reaction was stirred at $\mathrm{rt}$ for $16 \mathrm{~h}$. The mixture was concentrated under reduced pressure. The residue was diluted with EtOAc $(10 \mathrm{~mL})$, washed with saturated brine $(3 \times 10 \mathrm{~mL})$, and concentrated. The residue was dissolved in DMF $(2 \mathrm{~mL})$ and was purified by preparative HPLC using gradients of acetonitrile and water containing $0.1 \%$ of TFA. The fractions containing product were extracted with DCM, and the solvents were evaporated to give the title compound $(58 \mathrm{mg}, 88 \%) .{ }^{1} \mathrm{H}$ NMR $\left(400 \mathrm{MHz}\right.$, methanol- $\left.d_{4}\right): \delta$ $7.61(\mathrm{~s}, 1 \mathrm{H}), 7.48-7.37(\mathrm{~m}, 2 \mathrm{H}), 7.37-7.30(\mathrm{~m}, 1 \mathrm{H}), 7.25(\mathrm{~m}, 1 \mathrm{H})$, $5.29-5.22(\mathrm{~m}, 1 \mathrm{H}), 2.85(\mathrm{td}, J=6.3,1.6 \mathrm{~Hz}, 2 \mathrm{H}), 2.78(\mathrm{t}, J=6.3 \mathrm{~Hz}$, $2 \mathrm{H}), 2.53-2.34(\mathrm{~m}, 2 \mathrm{H}), 2.15-1.98(\mathrm{~m}, 5 \mathrm{H}), 1.94-1.73(\mathrm{~m}, 6 \mathrm{H})$. ${ }^{13} \mathrm{C}$ NMR $\left(101 \mathrm{MHz}, \mathrm{CDCl}_{3}\right): \delta 162.6,156.6,155.3,141.5,137.5$, $137.5,136.17,131.3,129.7,127.5,126.8,119.9,116.7,42.3,30.2$, $22.1,22.0,21.97,21.6,20.5,20.0,17.5$. HRMS $(m / z):[\mathrm{M}+\mathrm{H}]^{+}$ calcd for $\mathrm{C}_{21} \mathrm{H}_{22} \mathrm{~N}_{4} \mathrm{O}_{2}, 377.1978$; found, 377.1958 .

$\mathrm{N}$-(1-Phenyl-4,5,6,7-tetrahydro- $1 \mathrm{H}$-indazol-4-yl)-4,5,6,7-tetrahydro-1,2-benzoxazole-3-carboxamide (48). The title compound was synthesized using the method described for 44, starting from intermediate 11 , to give the title compound $(13 \mathrm{mg}, 53 \%) .{ }^{1} \mathrm{H}$ NMR $\left(400 \mathrm{MHz}\right.$, methanol- $\left.d_{4}\right): \delta 7.59(\mathrm{~s}, 1 \mathrm{H}), 7.54-7.44(\mathrm{~m}, 4 \mathrm{H})$, $7.40(\mathrm{~m}, 1 \mathrm{H}), 5.22(\mathrm{t}, J=5.21 \mathrm{~Hz}, 1 \mathrm{H}), 2.60-2.83(\mathrm{~m}, 7 \mathrm{H}), 1.95-$ $2.14(\mathrm{~m}, 2 \mathrm{H}), 1.82-1.94(\mathrm{~m}, 4 \mathrm{H}), 1.72-1.81(\mathrm{~m}, 2 \mathrm{H}) .{ }^{13} \mathrm{C}$ NMR $\left(101 \mathrm{MHz}\right.$, methanol- $\left.d_{4}\right): \delta 171.6,156.9,141.8,140.7,139.5,130.5$, 128.9, 125.0, 119.8, 114.2, 43.9, 30.6, 23.8, 23.4, 23.4, 23.0, 21.6, 21.1. HRMS $(m / z):[\mathrm{M}+\mathrm{H}]^{+}$calcd for $\mathrm{C}_{21} \mathrm{H}_{22} \mathrm{~N}_{4} \mathrm{O}_{2}, 363.1821$; found, 363.1827 .

$\mathrm{N}$-(1-Phenyl-4,5,6,7-tetrahydro-1H-indazol-4-yl)-4,5,6,7-tetrahydro-2,1-benzoxazole-3-carboxamide (49). The title compound was synthesized using the method described for 44 , starting from intermediate 11 to yield the title compound ( $13 \mathrm{mg}, 53 \%) .{ }^{1} \mathrm{H}$ NMR $\left(400 \mathrm{MHz}\right.$, methanol- $\left.d_{4}\right): \delta 7.60(\mathrm{~s}, 1 \mathrm{H}), 7.56-7.47(\mathrm{~m}, 4 \mathrm{H})$, $7.45-7.39(\mathrm{~m}, 1 \mathrm{H}), 5.24(\mathrm{t}, J=5.53 \mathrm{~Hz}, 1 \mathrm{H}), 2.88-2.81(\mathrm{~m}, 2 \mathrm{H})$, $2.80-2.67(\mathrm{~m}, 4 \mathrm{H}), 2.15-1.99(\mathrm{~m}, 2 \mathrm{H}), 1.94-1.73(\mathrm{~m}, 6 \mathrm{H}) .{ }^{13} \mathrm{C}$ NMR $\left(101 \mathrm{MHz}\right.$, methanol- $\left.d_{4}\right): \delta 163.5,159.0,157.2,141.9,140.9$, 139.6, 129.0, 125.11, 120.7, 119.8, 44.0, 30.8, 23.9, 23.3, 23.1, 22.6, 21.8, 21.5. HRMS $(m / z):[\mathrm{M}+\mathrm{H}]^{+}$calcd for $\mathrm{C}_{21} \mathrm{H}_{22} \mathrm{~N}_{4} \mathrm{O}_{2}, 363.1821$; found, 363.1403 .

(R)- $\mathrm{N}$-(1-(2-Fluoro-5-methylphenyl)-4,5,6,7-tetrahydro-1Hindazol-4-yl)-4,5,6,7-tetrahydrobenzo[c]isoxazole-3-carboxamide (50). 4,5,6,7-Tetrahydrobenzo[c] isoxazole-3-carboxylic acid (26 mg, $0.15 \mathrm{mmol})$, HATU (60 mg, $0.16 \mathrm{mmol}), 23$ (35 mg, 0.14 mmol), and DIPEA ( $50 \mu \mathrm{L}, 0.29 \mathrm{mmol})$ were mixed in DCM $(1.5$ $\mathrm{mL})$ and DMF $(0.2 \mathrm{~mL})$, and the mixture was stirred at rt overnight. The mixture was purified by column chromatography eluting with a 
gradient of EtOAc in hexanes $(20-70 \%)$ to give the title compound $(29 \mathrm{mg}, 49 \%) .{ }^{1} \mathrm{H}$ NMR $\left(400 \mathrm{MHz}, \mathrm{CDCl}_{3}\right): \delta 7.66(\mathrm{~s}, 1 \mathrm{H}), 7.31-$ $7.23(\mathrm{~m}, 1 \mathrm{H}$, overlapping with the solvent peak), 7.22-7.16 $(\mathrm{m}, 1 \mathrm{H})$, $7.11(\mathrm{dd}, J=10.1,8.5 \mathrm{~Hz}, 1 \mathrm{H}), 6.66(\mathrm{~d}, J=8.1 \mathrm{~Hz}, 1 \mathrm{H}), 5.36-5.25$ $(\mathrm{m}, 1 \mathrm{H}), 2.89(\mathrm{t}, J=6.0 \mathrm{~Hz}, 2 \mathrm{H}), 2.78(\mathrm{t}, J=6.2 \mathrm{~Hz}, 2 \mathrm{H}), 2.67-2.47$ (m, $2 \mathrm{H}), 2.37(\mathrm{~s}, 3 \mathrm{H}), 2.18-2.06(\mathrm{~m}, 1 \mathrm{H}), 1.96-1.69(\mathrm{~m}, 7 \mathrm{H}) .{ }^{13} \mathrm{C}$ NMR $\left(101 \mathrm{MHz}, \mathrm{CDCl}_{3}\right): \delta 162.6,156.7,155.4,154.4(\mathrm{~d}, J=248$ $\mathrm{Hz}), 142.0,139.2,134.9,130.6(\mathrm{~d}, J=7.3 \mathrm{~Hz}), 128.9,126.8(\mathrm{~d}, J=$ $12.2 \mathrm{~Hz}), 119.8,117.2,116.3(\mathrm{~d}, J=19.8 \mathrm{~Hz}), 42.3,30.1,22.1,22.0$, 21.9, $21.6(\mathrm{~d}, J=5.1 \mathrm{~Hz}), 20.7,20.5,20.0$. HRMS $(\mathrm{m} / \mathrm{z}):[\mathrm{M}+\mathrm{H}]^{+}$ calcd for $\mathrm{C}_{22} \mathrm{H}_{23} \mathrm{FN}_{4} \mathrm{O}_{2}$, 395.1883; found, 395.1880 .

(R)- $\mathrm{N}$-(1-(2-Fluorophenyl)-4,5,6,7-tetrahydro-1 $\mathrm{H}$-indazol-4yl)-5,6,7,8-tetrahydroimidazo[1,5-a]pyridine-1-carboxamide (51). Compound 21 (35 mg, $0.13 \mathrm{mmol}$ ), potassium 5,6,7,8tetrahydroimidazo[1,5-a]pyridine-1-carboxylate (30 mg, 0.14 mmol), HATU ( $55 \mathrm{mg}, 0.14 \mathrm{mmol}$ ), and DIPEA (68 $\mu \mathrm{L}, 0.39$ $\mathrm{mmol})$ were mixed in DCM $(1.5 \mathrm{~mL})$ and DMF $(0.15 \mathrm{~mL})$, and the mixture was stirred at rt overnight. The solvents were evaporated. The product was purified by column chromatography eluting with a gradient of methanol in DCM (2-10\%). One third of the isolated material was dissolved in DCM. The organic phase was washed with $\mathrm{NaHCO}_{3}$ (sat. aq). The organic phase was concentrated at reduced pressure, and the product was further dried under a vacuum to give the title compound $(6 \mathrm{mg}, 11 \%) .{ }^{1} \mathrm{H}$ NMR $\left(400 \mathrm{MHz}, \mathrm{CDCl}_{3}\right): \delta$ $7.67(\mathrm{~s}, 1 \mathrm{H}), 7.46(\mathrm{td}, J=7.6,1.7 \mathrm{~Hz}, 1 \mathrm{H}), 7.43-7.36(\mathrm{~m}, 1 \mathrm{H})$, $7.30-7.18(\mathrm{~m}, 3 \mathrm{H}$, overlapping with the solvent peak $), 5.39-5.25(\mathrm{~m}$, $1 \mathrm{H}), 4.01(\mathrm{t}, J=6.0 \mathrm{~Hz}, 2 \mathrm{H}), 3.21(\mathrm{t}, J=6.5 \mathrm{~Hz}, 2 \mathrm{H}), 2.65-2.44(\mathrm{~m}$, $2 \mathrm{H}), 2.16-2.02(\mathrm{~m}, 2 \mathrm{H}), 2.02-1.78(\mathrm{~m}, 6 \mathrm{H}) .{ }^{13} \mathrm{C}$ NMR $(101 \mathrm{MHz}$, $\left.\mathrm{CDCl}_{3}\right) 163.2,156.5(\mathrm{~d}, J=251.3 \mathrm{~Hz}), 141.8,139.7,134.3,133.2$, $130.2,129.9(\mathrm{~d}, J=7.6 \mathrm{~Hz}), 128.8,127.6(\mathrm{~d}, J=11.7 \mathrm{~Hz}), 124.9$ (d, $J$ $=4.0 \mathrm{~Hz}), 118.5,116.7(\mathrm{~d}, J=20.1 \mathrm{~Hz}), 43.8,41.5,30.5,22.8,22.3$, $21.7(\mathrm{~d}, J=4.7 \mathrm{~Hz}), 20.3,20.0$. HRMS $(\mathrm{m} / z):[\mathrm{M}+\mathrm{H}]^{+}$calcd for $\mathrm{C}_{21} \mathrm{H}_{22} \mathrm{FN}_{5} \mathrm{O}$, 380.1187; found, 380.1906 .

(R)- $\mathrm{N}$-(1-(2-Fluorophenyl)-4,5,6,7-tetrahydro- $1 \mathrm{H}$-indazol-4yl)imidazo[1,5-a]pyridine-3-carboxamide (52). Ethyl imidazo[1,5-a]pyridine-3-carboxylate $(25 \mathrm{mg}, 0.13 \mathrm{mmol}), 21$ (49 mg, 0.18 $\mathrm{mmol})$, and bis(trimethylaluminum)-1,4-diazabicyclo[2.2.2] octane adduct $(51 \mathrm{mg}, 0.20 \mathrm{mmol})$ were dissolved in THF $(2 \mathrm{~mL})$. The reaction mixture was stirred at $60{ }^{\circ} \mathrm{C}$ for $5 \mathrm{~h}$ under a nitrogen atmosphere. The solvent was removed at reduced pressure, and DCM and brine were added. The phases were separated, and the organic phase was filtered and concentrated. The mixture was purified by column chromatography, eluting with a gradient of EtOAc in hexanes (20-70\%) to give the title compound ( $31 \mathrm{mg}, 62 \%) .{ }^{1} \mathrm{H}$ NMR (400 $\left.\mathrm{MHz}, \mathrm{CDCl}_{3}\right): \delta 9.54(\mathrm{~d}, J=8.2 \mathrm{~Hz}, 1 \mathrm{H}), 7.71(\mathrm{~s}, 1 \mathrm{H}), 7.57(\mathrm{~d}, J=$ $9.1 \mathrm{~Hz}, 1 \mathrm{H}), 7.53(\mathrm{~d}, J=7.7 \mathrm{~Hz}, 1 \mathrm{H}), 7.48(\mathrm{td}, J=7.7,1.7 \mathrm{~Hz}, 1 \mathrm{H})$, $7.45(\mathrm{~d}, J=0.7 \mathrm{~Hz}, 1 \mathrm{H}), 7.44-7.37(\mathrm{~m}, 1 \mathrm{H}), 7.30-7.20(\mathrm{~m}, 2 \mathrm{H}$, overlapping with the solvent peak), 6.98 (ddd, $J=9.1,6.6,1.0 \mathrm{~Hz}$, $1 \mathrm{H}), 6.85$ (ddd, $J=7.2,6.6,1.3 \mathrm{~Hz}, 1 \mathrm{H}), 5.43-5.32(\mathrm{~m}, 1 \mathrm{H}), 2.68-$ $2.49(\mathrm{~m}, 2 \mathrm{H}), 2.22-2.09(\mathrm{~m}, 1 \mathrm{H}), 2.03-1.82(\mathrm{~m}, 3 \mathrm{H}) .{ }^{13} \mathrm{C}$ NMR $\left(101 \mathrm{MHz} \mathrm{CDCl}_{3}\right) 159.2,156.5(\mathrm{~d}, J=252 \mathrm{~Hz}), 141.9,139.6,133.8$, $130.1(\mathrm{~d}, J=7.7 \mathrm{~Hz}), 128.8,127.5(\mathrm{~d}, J=11.9 \mathrm{~Hz}), 125.8,124.9$ (d, $J$ $=3.9 \mathrm{~Hz}), 121.7,120.5,118.1,117.9,116.8(\mathrm{~d}, J=20.0 \mathrm{~Hz}), 114.8$, 42.0, 30.3, $21.7(\mathrm{~d}, J=4.7 \mathrm{~Hz}), 20.0$. HRMS $(\mathrm{m} / z):[\mathrm{M}+\mathrm{H}]^{+}$calcd for $\mathrm{C}_{21} \mathrm{H}_{18} \mathrm{FN}_{5} \mathrm{O}$, 376.1774; found, 376.1764.

Ethyl 3-[4-(4,5,6,7-Tetrahydro-1,2-benzoxazole-3-amido)4,5,6,7-tetrahydro-1 $\mathrm{H}$-indazol-1-yl]benzoate (53). The title compound was synthesized using the method described for 44, starting from intermediate 16 to give (108 mg, 42\%). ${ }^{1} \mathrm{H}$ NMR (400 $\left.\mathrm{MHz}, \mathrm{CDCl}_{3}\right): \delta 8.14-8.15(\mathrm{~m}, 1 \mathrm{H}), 8.03(\mathrm{~m}, 1 \mathrm{H}), 7.72(\mathrm{~m}, 1 \mathrm{H})$, $7.67(\mathrm{~s}, 1 \mathrm{H}), 7.55(\mathrm{t}, J=8.0 \mathrm{~Hz}, 1 \mathrm{H}), 6.95(\mathrm{~d}, J=8.1 \mathrm{~Hz}, 1 \mathrm{H}), 5.30$ $(\mathrm{m}, 1 \mathrm{H}), 4.40(\mathrm{q}, J=7.2 \mathrm{~Hz}, 2 \mathrm{H}), 2.84-2.71(\mathrm{~m}, 6 \mathrm{H}), 2.13(\mathrm{~m}, 1 \mathrm{H})$, $1.97-1.85(\mathrm{~m}, 5 \mathrm{H}), 1.81-1.77(\mathrm{~m}, 2 \mathrm{H}), 1.41(\mathrm{t}, J=7.2 \mathrm{~Hz}, 3 \mathrm{H}) .{ }^{13} \mathrm{C}$ NMR $\left(\mathrm{CDCl}_{3}\right): \delta 170.6,166.6,159.7,155.2,140.2,139.7,138.9$, 136.1, 129.7, 126.0, 125.8, 121.9, 118.9, 113.7, 73.0, 69.2, 42.3, 40.1, $29.8,23.4,22.922 .8,22.4,22.0,20.3,20.2,10.7 . \mathrm{ES}^{+}: m / z 435[\mathrm{M}+$ $\mathrm{H}]^{+}$.

(R)-3-[4-(4,5,6,7-Tetrahydro-1,2-benzoxazole-3-amido)4,5,6,7-tetrahydro-1 $\mathrm{H}$-indazol-1-yl]benzoic Acid (54). Compound 24 (85 mg, $0.284 \mathrm{mmol}$ ), 4,5,6,7-tetrahydrobenzo[d]- isoxazole-3-carboxylic acid (48 mg, $0.284 \mathrm{mmol}$ ), 1,3,5-tripropyl1,3,5-triphosphinane-2,4,6-trione ( $500 \mu \mathrm{L}, 0.840 \mathrm{mmol})$, and triethylamine $(200 \mu \mathrm{L}, 1.42 \mathrm{mmol})$ were mixed in THF $(1 \mathrm{~mL})$. The mixture was stirred at rt overnight. The solvents were evaporated, and the mixture was purified by column chromatography on silica eluting with gradients of EtOAc in hexanes $(25-50 \%)$. The solvents were evaporated to give propan-2-yl-3-[(4R)-4-(4,5,6,7-tetrahydro-1,2benzoxazole-3-amido)-4,5,6,7-tetrahydro- $1 H$-indazol-1-yl] benzoate as an oil $(90 \mathrm{mg}, 70 \%) .{ }^{1} \mathrm{H}$ NMR (400 MHz, methanol- $\left.d_{4}\right): \delta 8.12(\mathrm{~m}$, $1 \mathrm{H}), 8.03(\mathrm{~m}, 1 \mathrm{H}), 7.78-7.73(\mathrm{~m}, 1 \mathrm{H}), 7.67-7.61(\mathrm{~m}, 2 \mathrm{H}), 5.26-$ $5.23(\mathrm{~m}, 1 \mathrm{H}), 2.88-2.75(\mathrm{~m}, 2 \mathrm{H}), 2.75-2.65(\mathrm{~m}, 4 \mathrm{H}), 2.18-1.99$ $(\mathrm{m}, 2 \mathrm{H}), 1.89(\mathrm{dd}, J=6.0,2.2 \mathrm{~Hz}, 4 \mathrm{H}), 1.80(\mathrm{~m}, 2 \mathrm{H}) 1.39(\mathrm{~d}, J=6.2$ $\mathrm{Hz}, 6 \mathrm{H}) . \mathrm{ES}^{+}: m / z 449[\mathrm{M}+\mathrm{H}]^{+}$.

Propan-2-yl-3-[(4R)-4-(4,5,6,7-tetrahydro-1,2-benzoxazole-3amido)-4,5,6,7-tetrahydro- $1 \mathrm{H}$-indazo-1-yl] benzoate $(45 \mathrm{mg}, 0.10$ mmol) was treated with $4 \mathrm{M} \mathrm{NaOH}(5 \mathrm{~mL})$ in $\mathrm{MeOH}(5 \mathrm{~mL})$ at $50{ }^{\circ} \mathrm{C}$ for $1 \mathrm{~h}$, then acidified with $\mathrm{HCl}$ and extracted to EtOAc, dried $\left(\mathrm{Na}_{2} \mathrm{SO}_{4}\right)$, and evaporated. The material was purified by acidic preparative HPLC to give the title compound $(35 \mathrm{mg}, 61 \%$, purity 92\%). ${ }^{1} \mathrm{H}$ NMR (400 MHz, methanol- $\left.d_{4}\right): \delta 8.65(\mathrm{~d}, J=8.1 \mathrm{~Hz}, 1 \mathrm{H})$, 8.18-8.11 (m, 1H), 8.10-8.04 (m, 1H), 7.81-7.73 (m, 1H), 7.67$7.62(\mathrm{~m}, 2 \mathrm{H}), 5.25(\mathrm{q}, J=6.9,5.8 \mathrm{~Hz}, 1 \mathrm{H}), 2.89-2.71(\mathrm{~m}, 4 \mathrm{H})$, 2.71-2.65 (m, 2H), 2.19-1.99 (m, 2H), 1.97-1.85 (m, 4H), 1.85$1.73(\mathrm{~m}, 2 \mathrm{H}), 1.53(\mathrm{t}, J=7.3 \mathrm{~Hz}, 1 \mathrm{H}) . \mathrm{ES}^{+}: m / z 407[\mathrm{M}+\mathrm{H}]^{+}$.

Aqueous Solubility Assay. For evaluation of the aqueous

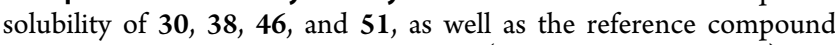
brequinar, Prima HT System solution (SS, $p \mathrm{ION}$ no. 110151) was diluted to $1 \times$ solution in Milli- $\mathrm{Q}_{2} \mathrm{O}$ with the $\mathrm{pH}$ adjusted to 7.4 with $\mathrm{NaOH}$. Twenty $\mathrm{mM}$ compound stocks solubilized in DMSO were diluted $100 \times$ in SS. Compounds were aliquoted at $500 \mu \mathrm{L}$ volumes in 96-deep-well plates and incubated for $4 \mathrm{~h}$ with shaking at rt $(250 \mathrm{rpm})$. Then, $300 \mu \mathrm{L}$ was taken from each well and filtered using $0.22 \mu \mathrm{m}$ filter plates ( $p \mathrm{ION}$ no. 110037). A $75 \mu \mathrm{L}$ aliquot was taken, following filtration, and mixed with $75 \mu \mathrm{L}$ of $100 \%$ isopropanol (Spectrochem no. 010913) and scanned at 190-400 nm on a SpectraMax Plus spectrophotometer (version 2.1, Molecular Devices). Reference standards for stock and positive controls were conducted by adding $5 \mu \mathrm{L}$ of $20 \mathrm{mM}$ to $95 \mu \mathrm{L}$ of $100 \%$ isopropanol (Spectrochem no. 010913). Then, $75 \mu \mathrm{L}$ of SS, $70 \mu \mathrm{L}$ of $100 \%$ isopropanol (Spectrochem no. 010913), and $5 \mu \mathrm{L}$ of the diluted reference stock was added to the UV plate and scanned at 190-400 $\mathrm{nm}$ on a SpectraMax Plus spectrophotometer (version 2.1, Molecular Devices). Solubility was measured by taking the $\lambda_{\max }$ of each compound using the following formula:

$$
\text { aqueous solubility }(\mu \mathrm{M})=2 \times\left(\mathrm{OD}_{\text {sample }} / \mathrm{OD}_{\text {reference }}\right) \times C_{\mathrm{R}}
$$

Compounds were compared to the reference standard, caffeine (SigmaAldrich no. C0750), and diethylstilbestrol (SigmaAldrich no. D4628). $C_{R}$ in the above formula is the concentration of the reference standard $(33.4 \mu \mathrm{M})$.

Kinetic solubility for compounds (R)-HZ00 and (R)-HZ05 was performed using a TECAN IVO liquid handling system from a 10 mM DMSO stock solution. The test compound was added to 100 $\mathrm{mM}$ potassium phosphate buffer, $\mathrm{pH} 7.4$, to a final compound concentration of $100 \mu \mathrm{M}$ containing $1 \%$ DMSO and incubated at 37 ${ }^{\circ} \mathrm{C}$ for $\geq 20 \mathrm{~h}$ in a heater-shaker at $900 \mathrm{rpm}$. After incubation, the samples were centrifuged at $3000 \mathrm{~g}$ at $37^{\circ} \mathrm{C}$ for $30 \mathrm{~min}$ to pellet insoluble material, and an aliquot of the supernatant was taken for analysis. After dilution of the sample, the concentration of the compound in the supernatant was quantified by LC-MS/MS analysis. The solubilized compound was quantified based on a standard curve $(1-1000 \mathrm{nM})$.

Metabolite Formation and Stability. Metabolite formation was measured by incubation in MS vials of $10 \mu \mathrm{M}(R)$-HZ05 in $100 \mathrm{mM}$ phosphate buffer pH $7.4\left(450 \mu \mathrm{L}, 37^{\circ} \mathrm{C}\right)$ with $20 \mathrm{mg} / \mathrm{mL}$ pooled CD-1 MLM from a female donor ( $25 \mu \mathrm{L}$; XenoTech LLC no. M1500, lot no. 1310224) and $75 \mu \mathrm{L}$ of $10 \mathrm{mM}$ NADPH dissolved in cold 100 $\mathrm{mM}$ phosphate buffer. The total incubation volume was $0.5 \mathrm{~mL}$. The compound was incubated at $37{ }^{\circ} \mathrm{C}$ for $0,10,20,40$, and $60 \mathrm{~min}$ in a 
shaker at $900 \mathrm{rpm}$. The reaction was stopped by adding 1 volume $(0.5$ $\mathrm{mL}$ ) of ice-cold acetonitrile. Acetonitrile was added to the control vial prior to the addition of NADPH. After incubation was stopped, the samples were centrifuged at $3000 \mathrm{~g}$ for $30 \mathrm{~min}$ at $4{ }^{\circ} \mathrm{C}$, and the supernatant was evaporated using a GeneVac at $50{ }^{\circ} \mathrm{C}$. The samples were reconstituted in $150 \mu \mathrm{L}$ of acetonitrile/water (50:50) and once again centrifuged $\left(3000 \mathrm{~g}, 4{ }^{\circ} \mathrm{C}\right)$. Metabolites were identified using a linear ion trap (QTrap6500, Sciex) coupled with the UHPLC system (Acquity UPLC, Waters). Metabolites were separated on a BEH $\mathrm{C}_{18}$ column $(2.1 \times 100 \mathrm{~mm}, 1.7 \mu \mathrm{m}$, Waters $)$ using a linear gradient. The elution profile used was $0.00-0.50 \mathrm{~min}, 1 \% \mathrm{~B} ; 8.00 \mathrm{~min}, 90 \% \mathrm{~B}$; 9.01-9.00 min, $100 \%$ B; $9.01-10.00 \mathrm{~min}, 1 \% \mathrm{~B}$. Mobile phase A consisted of $0.1 \% \mathrm{HCOOH} / 5 \% \mathrm{ACN}$ and mobile phase B was $0.1 \%$ $\mathrm{HCOOH} / 95 \%$ ACN. The injection volume was $10 \mu \mathrm{L}$. The remaining area (\%) was calculated by eq 2 :

$$
\text { area remaining } \%=\frac{\text { peak area }}{\text { total area }(\text { metabolite }+ \text { parent })} \times 100
$$

The microsomal metabolic stability assay utilized pooled human liver microsomes (mixed gender, XenoTech LLC no. H0610 batch 1210153 ) or mouse liver microsomes (mouse (CD-1) pooled male XenoTech LLC, no. M1000 batch 0710393), with supplemented cofactor NADPH (PanReac Applichem, no. A1395,0500, lot $75004465)$ to primarily facilitate CYP reactivity against the target compound. The assay was performed using an automated liquid handling system (Hamilton). One $\mu \mathrm{M}$ of the target compound and $0.5 \mathrm{mg} / \mathrm{mL}$ of liver microsomes were diluted in $0.1 \mathrm{M}$ phosphate buffer $\mathrm{pH} 7.4(\mathrm{LM})$ to a final incubation volume of $150 \mu \mathrm{L}$. The reaction was initiated by the addition of $1 \mathrm{mM} \mathrm{NADPH}$ in $0.1 \mathrm{M}$ phosphate buffer $\mathrm{pH}$ 7.4. The incubation times were $0,5,15$, and 40 min with the reaction being quenched by the addition of $100 \mu \mathrm{L}$ icecold acetonitrile containing $100 \mathrm{nM}$ warfarin, used as an analytical internal standard. The sealed plate was centrifuged at $3000 \mathrm{~g}$ for 15 min at $4{ }^{\circ} \mathrm{C}$, and $10 \mu \mathrm{L}$ of supernatant aliquot was injected into the LC-MS/MS system.

A Waters XEVO TQ triple-quadrupole mass spectrometer coupled to a Waters ACQUITY UPLC (Waters Corp) was used for the detection of the parent compound. For chromatographic separation, a linear gradient was used: $1 \% \mathrm{~B}$ to $90 \% \mathrm{~B}$ over 2 min. A C ${ }_{18}$ BEH $(2 \times$ $50 \mathrm{~mm}, 1.7 \mu \mathrm{m}$; Waters Corp.) was used for separation. Mobile phase A consisted of $5 \%$ acetonitrile with $0.1 \%$ formic acid and mobile phase B $100 \%$ acetonitrile with $0.1 \%$ formic acid. The flow rate was $0.5 \mathrm{~mL} /$ $\mathrm{min}$. The analytes were positively ionized in electrospray (ESI) and monitored in MRM mode with the following transition: $337.23>$ 215.21 (Cone, $46 \mathrm{~V}$; CE, $16 \mathrm{eV}$ ) for (R)-HZ00 and $337.09>214.99$ (Cone, $22 \mathrm{~V}$; CE, $22 \mathrm{eV}$ ) for $(R)-\mathrm{HZ} 05$. Five $\mu \mathrm{L}$ of the sample was injected and analyzed by LC-MS/MS.

The metabolic stability of compounds $30,38,46,51$, and brequinar was analyzed using the following method: $1 \mathrm{mM}$ compound or positive controls were spiked into a $1120 \mu \mathrm{L}$ aliquot of $50 \mathrm{mM}$ potassium phosphate buffer ( $\mathrm{pH} 7.4$ ) containing $1.42 \mathrm{mg} / \mathrm{mL}$ HLM (BD Gentest no. 452165) or MLM (Gibco no. MSMCPL) to give a final concentration of $1.0 \mathrm{mg} / \mathrm{mL}$ HLM/MLM and $1 \mu \mathrm{M}$ compound. Then, $70 \mu \mathrm{L}$ of the mixture was added to each well of a 96-well plate and incubated at $37^{\circ} \mathrm{C}$ for $5 \mathrm{~min}$. Reactions were initiated by adding $\mathrm{NADPH}$ or blank buffer to a final concentration of $1 \mathrm{mM}$ in each sample. Reactions were terminated by adding $100 \mu \mathrm{L}$ of ice-cold acetonitrile (RANKEM no. A2094) containing $6.7 \times 10^{-7} \mathrm{~mol}$ glipizide as an internal standard (Sigma-Aldrich no. G117) at 0, 5, 15, 30 , and $60 \mathrm{~min}$. Plates were centrifuged at $3220 \mathrm{~g}$ for $15 \mathrm{~min}$ with 100 $\mu \mathrm{L}$ aliquots taken for MS analysis. LC-MS/MS was conducted on an Acquity UPLC (Waters) coupled to an API-4000 (MDS Sciex, Applied Biosystems). Parent compound disappearance was monitored in MRM mode in both positive and negative mode. Half-life ( $\mathrm{min}$ ) was calculated using the gradient of the line determined from a plot of peak area ratio against time to yield $k$.

$$
t_{1 / 2}=\frac{0.693}{k}
$$

DHODH Enzymatic Assay. All DHODH inhibitor dilutions for the kinetic enzymatic assay were prepared in DMSO. Five $\mu \mathrm{L}$ of these dilutions were mixed with $45 \mu \mathrm{L}$ of the reaction mix $(1 \mathrm{mM}$ DLdihydroorotic acid (Sigma-Aldrich no. D7003), $100 \mu \mathrm{M}$ 2,3dimethoxy-5-methyl-p-benzoquinone (Sigma-Aldrich no. D9150), and $100 \mu \mathrm{M}$ freshly prepared and filtered 2,6-dichloroindophenol sodium salt hydrate (DCIP; Sigma-Aldrich no. D1878)). The reaction was started by the addition of $50 \mu \mathrm{L}$ of $4 \mathrm{nM}$ recombinant human DHODH (prepared as described in Walse et al. ${ }^{53}$ ), unless stated otherwise, diluted in enzyme buffer $(50 \mathrm{mM}$ Trizma base, $\mathrm{pH} 8.0$ (Sigma-Aldrich no. T1503), $150 \mathrm{mM} \mathrm{KCl}$ (Sigma-Aldrich no. P5405), and 0.1\% Triton X-100 (Sigma-Aldrich no. X100)). Enzymatic activity was measured by loss of absorbance of DCIP at $595 \mathrm{~nm}$ in a time course kinetic reaction with the following reads: $8 \times$ $2 \mathrm{~min}, 8 \times 3 \mathrm{~min}, 6 \times 5 \mathrm{~min}$ at rt. DHODH's $V_{\max }$ was estimated by linear regression within the linear decrease in absorbance (between 10 and $25 \mathrm{~min}$ ), for each concentration of inhibitor tested. The $\mathrm{IC}_{50}$ was calculated by eq 4 :

$$
V_{\max }([I])=\frac{V_{\max }(\text { DMSO })}{2}
$$

The $\mathrm{IC}_{50}$ was calculated through the intercept of the inhibitor concentrations that reduced the enzyme activity more than 50\% and less than $50 \%$ compared to the DMSO control.

Cell Culture. The ARN8 reporter cell line containing the p53 reporter RGC $\Delta$ Fos-LacZ construct has been described previously. ${ }^{54,55}$ HNDF cells were purchased from PromoCell (Heidelberg, Germany, no. C-12300). Both cell lines were grown in DMEM (HyClone no. SH30243.01) supplemented with $10 \%$ heat inactivated FBS (HyClone no. SV30160.03) and $100 \mathrm{U} / \mathrm{mL}$ of pen/strep (HyClone no. SV30010). The cell lines were negative for mycoplasma contamination after testing with the MycoAlert kit (Lonza, no. LT07-318).

Assay for p53 Transcription Factor Function in Cells (CPRG Assay). ARN8 cells were seeded in a 96-well plate at a density of $2 \times$ $10^{4}$ cells per well in a volume of $200 \mu \mathrm{L}$ in growth medium. Following a $24 \mathrm{~h}$ incubation, cells were treated with $22 \mu \mathrm{L}$ of the indicated compound or vehicle (DMSO; Sigma-Aldrich no. D8418) diluted in growth medium. The final concentration of DMSO in all samples was $0.1 \%$. Nutlin-3a with a final concentration of $2 \mu \mathrm{M}$ was included as a positive control in all assays. Where indicated, the medium was supplemented with uridine (Sigma-Aldrich no. U3003) to a final concentration of $100 \mu \mathrm{M}$. Fresh stock solution of uridine was prepared in growth medium and filtered through a $0.2 \mu \mathrm{m}$ sterile filter. After $16 \mathrm{~h}$ of treatment, the medium was removed and the cells were washed once with $1 \times$ PBS (HyClone no. SH30028.02). Subsequently, $50 \mu \mathrm{L} 1 \times$ lysis buffer (Promega no. E3971) was added to each well, and the plates were stored at $-20{ }^{\circ} \mathrm{C}$ for at least 2 h. After thawing the cell lysate, $150 \mu \mathrm{L}$ of CPRG mix $(0.1 \mathrm{M}$ phosphate buffer, $\mathrm{pH} 7.5\left(0.2 \mathrm{M} \mathrm{Na}_{2} \mathrm{HPO}_{4}\right.$ (Sigma-Aldrich no. S7907), $0.2 \mathrm{M} \mathrm{NaH}_{2} \mathrm{PO}_{4}$ (Sigma-Aldrich no. S5011), $\mathrm{dH}_{2} \mathrm{O}$ ), $4 \mathrm{mg} /$ $\mathrm{mL}$ chlorophenol red- $\beta$-D-galactopyranoside monosodium salt (Roche no. 884308) diluted in $0.1 \mathrm{M}$ phosphate buffer, $\mathrm{pH} 7.5$, and $0.1 \mathrm{M}$ $\mathrm{MgCl}_{2}$ (Sigma-Aldrich no. M8266)/4.5 M $\beta$-mercaptoethanol (Sigma no. M6250)) were added to each well. $\beta$-Galactosidase activity was measured after $24 \mathrm{~h}$ at $590 \mathrm{~nm}$ on a BioRad iMark Microplate Absorbance Reader or Tecan Spark 20 M Multimode Microplate Reader. The fold change was calculated in Microsoft Excel for Mac v. 16.16.8 based on the increased absorption compared to the DMSO control. The data was plotted with GraphPad Prism v.7, displaying the mean value \pm SD of three technical replicates.

Sulforhodamine B Cell Viability/Growth Assay. ARN8 or HNDF cells were seeded in 96-well plates at a density of $5 \times 10^{2}$ cells per well or $15 \times 10^{2}$ cells per well, respectively, in a volume of $200 \mu \mathrm{L}$. Following a $24 \mathrm{~h}$ incubation, cells were treated with $22 \mu \mathrm{L}$ of the indicated compound or vehicle (DMSO; Sigma-Aldrich no. D8418) diluted in growth medium. The final concentration of DMSO in all samples was $0.1 \%$. Where indicated, the medium was supplemented with uridine (Sigma-Aldrich no. U3003) to a final concentration of $100 \mu \mathrm{M}$. Fresh stock solutions of uridine was prepared in growth 
medium and filtered through a $0.2 \mu \mathrm{m}$ sterile filter. After a $72 \mathrm{~h}$ incubation, the medium was removed and replaced with $150 \mu \mathrm{L}$ of $1 \times$ PBS (HyClone no. SH30028.02) and $50 \mu \mathrm{L}$ of $40 \% \mathrm{w} / \mathrm{v}$ trichloroacetic acid (Sigma-Aldrich no. T4885) in $\mathrm{dH}_{2} \mathrm{O}$. Plates were incubated at $4{ }^{\circ} \mathrm{C}$ for $1 \mathrm{~h}$ to fix the cells. After fixation, the wells were washed three times with water and left to dry and afterward stained with $50 \mu \mathrm{L}$ of $0.4 \% \mathrm{w} / \mathrm{v}$ sulforhodamine B (Sigma-Aldrich no. S9012) dissolved in 1\% v/v acetic acid (Sigma-Aldrich no. 33209-M) and incubated at $\mathrm{rt}$ for $30 \mathrm{~min}$ protected from light. After incubation, excess dye was washed out with $1 \% \mathrm{v} / \mathrm{v}$ acetic acid diluted in $\mathrm{H}_{2} \mathrm{O}$, and the plates were left to dry. The remaining dye was solubilized with $100 \mu \mathrm{L}$ of $10 \mathrm{mM}$ unbuffered Tris-base (Sigma-Aldrich no. $\mathrm{T} 1503)$. The plates were left on a shaker for $10 \mathrm{~min}$ prior to reading the absorption at $490 \mathrm{~nm}$ on a BioRad iMark Microplate Absorbance Reader or Tecan Spark 20 M Multimode Microplate Reader. The growth/viability \% was calculated in Microsoft Excel for Mac v. 16.16.8 based on the decrease in absorption compared to the DMSO control, normalized to $100 \%$. The data was plotted with GraphPad Prism v.7 displaying the mean value \pm SD of three technical replicates.

Western Blotting. ARN8 cells were seeded in six-well plates at a density of $15 \times 10^{4}$ cells per well in a volume of $2 \mathrm{~mL}$. After $24 \mathrm{~h}$ incubation, the cells were treated with the indicated compounds as described in the figure legends. For the uridine supplementation experiments, $100 \mu \mathrm{M}$ of uridine dissolved as described above was added with the drugs in the indicated samples. For the apoptosis experiments, $20 \mu \mathrm{M}$ Z-VAD-FMK (Selleckchem no. S7023) was added $4.5 \mathrm{~h}$ prior to harvesting. The treatments used as controls in both experiments were $20 \mu \mathrm{M}$ etoposide (Sigma-Aldrich no. E1383), $2 \mu \mathrm{M}$ nutlin-3a (Sigma-Aldrich no. SML0580), $2 \mathrm{mM}$ hydroxyurea crystalline dissolved in sterile filtered Milli- $\mathrm{QH}_{2} \mathrm{O}$ (Sigma-Aldrich no. $\mathrm{H} 8627$ ), or $1 \mu \mathrm{M}$ staurosporine (Roche no. 11055682001).

After treatment with the indicated compounds, the culture medium was removed, and cells were washed twice with $1 \times$ PBS. The samples were lysed with $150 \mu \mathrm{L}$ of $1 \times$ LDS sample buffer (106 mM Tris- $\mathrm{HCl}$ (Sigma-Aldrich no. T5941), $141 \mathrm{mM}$ Trisma base (Sigma-Aldrich no. 1503), $\mathrm{pH} 8.5,2 \%$ lithium dodecyl sulfate (LDS), (Sigma-Aldrich no. L9781), 10\% glycerol (Sigma-Aldrich no. G5516), and $0.51 \mathrm{mM}$ EDTA (Sigma-Aldrich no. ED)), heated at $95{ }^{\circ} \mathrm{C}$ for $5 \mathrm{~min}$, and sonicated for $3 \times 10 \mathrm{~s}$. After brief centrifugation at $16000 \mathrm{~g}$, protein concentrations were determined with the Bio-Rad DC Protein Assay kit (BioRad no. 50-0116). Protein concentration was normalized between samples, and $4 \times$ Laemmli buffer (BioRad no. 161-0747) was added to a final concentration of $1 \times$. DTT (Sigma-Aldrich no. 43819), used as reducing agent, was added to a final concentration of $100 \mathrm{mM}$, and samples were heated at $95{ }^{\circ} \mathrm{C}$ for $5 \mathrm{~min}$. Equivalent amounts of total protein were loaded on 12-well stain free $4-15 \%$ TGX gels (BioRad no. 456-8085) in standard tris-glycine running buffer (BioRad no. 161-0732), and the electrophoresis was run at 150 V. Gels were activated for 5 min using the ChemiDoc Touch (BioRad no. 170-8370) stain free gel activation protocol. Subsequently, proteins were transferred on a PVDF membrane (Trans-Blot Turbo kit, BioRad no. 170-4150) using the standard semidry transfer of the BioRad Trans-Blot Turbo transfer system preset program (30 min, 25 $\mathrm{V}, 1 \mathrm{~A})$.

The membranes were blocked with $5 \%$ milk in PBS-T $(1 \times$ PBS, $0.1 \%$ Tween 20 (Sigma-Aldrich no. P9416)) or, if phosphorylated proteins were detected, with 5\% BSA (Sigma-Aldrich no. A9647) in TBS-T (407 mM Trizma base, $2.7 \mathrm{M} \mathrm{NaCl}$ (Sigma-Aldrich no. 71382 ), $\mathrm{pH} 7.6,0.1 \%$ Tween-20). Incubation with primary antibodies was carried out overnight at $4{ }^{\circ} \mathrm{C}$ under gentle agitation. Incubation with secondary antibodies occurred at $\mathrm{rt}$ for $1 \mathrm{~h}$ on a shaker. Images were acquired using a ChemiDoc Touch system for both the chemiluminescence mode after development using Clarity Western ECL Substrate (BioRad no. 170-5061) or stain-free membrane mode for the total protein loading. All primary antibodies are listed in Table S3. As secondary antibodies, either Rabbit Anti Mouse-HRP (DAKO no. P0261) or Swine Anti Rabbit-HRP (DAKO no. 0217) were used. Full size blots are presented in the Supporting Information.
Live Cell Imaging Analysis. ARN8 cells were seeded in a 96-well plate at a density of $4 \times 10^{3}$ cell per well in $100 \mu \mathrm{L}$ of the medium. After a $24 \mathrm{~h}$ incubation, cells were treated with $11 \mu \mathrm{L}$ of the indicated compounds (20 nM of HZ compounds, $250 \mathrm{nM}$ brequinar, or $1 \mu \mathrm{M}$ staurosporine) or vehicle (DMSO; Sigma-Aldrich no. D8418) diluted in growth medium supplemented with $2 \mu \mathrm{M}$ caspase $3 / 7$ reagent (Invitrogen no. C10423) and $0.3 \mu \mathrm{M}$ YOYO-3 (Invitrogen no. Y3606). Where indicated, the medium was supplemented with uridine (Sigma-Aldrich no. U3003) to a final concentration of $100 \mu \mathrm{M}$ or ZVAD-FMK (Selleckchem no. S7023) to a final concentration of 20 $\mu \mathrm{M}$. The final DMSO concentration in all wells was $0.2 \%$. Plates were placed in an IncuCyte $\mathrm{S} 3$ system located inside a $\mathrm{CO}_{2}$ incubator for $48.5 \mathrm{~h}$ with images taken every $2 \mathrm{~h}$ after an initial incubation period of $30 \mathrm{~min}$. The results, confluence \%, and the number of positive cells for caspase 3/7 and YOYO-3 were analyzed with the IncuCyte S3 2018A Rev 1 software. The confluence \% was estimated as the percent of the image area occupied by objects. The number of positive cells for caspase 3/7 and YOYO-3 in each well was normalized to the cell confluence \% in the well in Microsoft Excel for Mac v. 16.16.8. After normalization, the data was plotted with GraphPad Prism v.7, displaying the mean value \pm SD between three technical replicates.

\section{ASSOCIATED CONTENT}

\section{(5) Supporting Information}

The Supporting Information is available free of charge at https://pubs.acs.org/doi/10.1021/acs.jmedchem.9b01658.

Inhibitory activity of analogues, effect of HZOO and HZ05 enantiomers and analogues on p53 transcription factor activity and cell growth/viability, DHODH inhibitors that do not activate markers of DNA damage, effect of DHODH inhibition on proteins upstream the caspase cascade, whole blots, ligand-lipophilic efficiency, effect of compound $\mathbf{5 1}$ on 468 kinases, and list of antibodies used for western blotting (PDF)

HPLC and HRMS raw data of selected compounds (PDF)

Molecular formula strings (CSV)

\section{AUTHOR INFORMATION}

\section{Corresponding Author}

Gergana Popova - Department of Microbiology, Tumor and Cell Biology, Karolinska Institutet, SE-171 65 Stockholm,

Sweden; (1) orcid.org/0000-0001-9804-4041; Phone: (+46)

760675930; Email: gergana.popova@ki.se

\section{Authors}

Marcus J. G. W. Ladds - Department of Microbiology, Tumor and Cell Biology and SciLifeLab, Department of Microbiology, Tumor and Cell Biology, Karolinska Institutet, SE-171 65 Stockholm, Sweden

Lars Johansson - Chemical Biology Consortium Sweden, SciLifeLab, Department of Medical Biochemistry and Biophysics, Karolinska Institutet, SE-171 21 Stockholm, Sweden

Aljona Saleh - SciLifeLab, Drug Discovery and Development Platform, ADME of Therapeutics Facility, Department of Pharmacy, Uppsala University, SE-751 23 Uppsala, Sweden

Johanna Larsson - SciLifeLab, Drug Discovery and Development Platform, Department of Medicinal Chemistry, Uppsala University, SE-751 23 Uppsala, Sweden

Lars Sandberg - SciLifeLab, Drug Discovery and Development Platform, Department of Medicinal Chemistry, Uppsala University, SE-751 23 Uppsala, Sweden; SciLifeLab, Drug Discovery and Development Platform, Department of Organic Chemistry, Stockholm University, SE-171 21 Stockholm, Sweden 
Sara Häggblad Sahlberg - SciLifeLab, Drug Discovery and Development Platform, Department of Biochemistry and Biophysics, Stockholm University, SE-171 21 Stockholm, Sweden

Weixing Qian - Chemical Biology Consortium Sweden, Laboratories for Chemical Biology Umeå, Umeå University, SE90187 Umeå, Sweden

Hjalmar Gullberg - SciLifeLab, Drug Discovery and Development Platform, Department of Biochemistry and Biophysics, Stockholm University, SE-171 21 Stockholm, Sweden

Neeraj Garg - SciLifeLab, Drug Discovery and Development Platform, Department of Medicinal Chemistry, Uppsala University, SE-751 23 Uppsala, Sweden

Anna-Lena Gustavsson - Chemical Biology Consortium Sweden, SciLifeLab, Department of Medical Biochemistry and Biophysics, Karolinska Institutet, SE-171 21 Stockholm, Sweden

Martin Haraldsson - Chemical Biology Consortium Sweden, SciLifeLab, Department of Medical Biochemistry and Biophysics, Karolinska Institutet, SE-171 21 Stockholm, Sweden

David Lane - Department of Microbiology, Tumor and Cell Biology, Karolinska Institutet, SE-171 65 Stockholm, Sweden

Ulrika Yngve - SciLifeLab, Drug Discovery and Development Platform, Department of Medicinal Chemistry, Uppsala University, SE-751 23 Uppsala, Sweden

Sonia Lain - Department of Microbiology, Tumor and Cell Biology and SciLifeLab, Department of Microbiology, Tumor and Cell Biology, Karolinska Institutet, SE-171 65 Stockholm, Sweden

Complete contact information is available at:

https://pubs.acs.org/10.1021/acs.jmedchem.9b01658

\section{Author Contributions}

S.L. designed the study. G.P., M.J.G.W.L., and S.L. wrote the original draft. L.J., A.S., M.H., and U.Y. wrote sections of the manuscript. L.J., J.L., L.S., W.Q., N.G., M.H., and U.Y. designed, synthesized, and/or characterized the compounds. M.J.G.W.L. and A.S. performed and/or analyzed the solubility and in vitro metabolic stability assays. G.P., S.H.S., and H.G. performed and/or analyzed the DHODH enzymatic assays. G.P. performed and analyzed the in vitro biological assays (CPRG, SRB assays, $\mathrm{WB}$ and live cell imaging). G.P., M.J.G.W.L., L.J., A.S., J.L., L.S., M.H., D.L., U.Y., and S.L. reviewed and/or edited the manuscript. G.P., M.J.G.W.L., L.S., and U.Y. prepared figures. M.J.G.W.L. and U.Y. draw synthetic schemes and compound structures. L.S. and A.L.G. performed ligand interaction analysis.

\section{Funding}

This work was financially supported by grants from Cancerfonden (Swedish Cancer Society) CAN 2014-702, CAN 2017671, Barncancerfonden TJ2014-0013, Vetenskapsrådet (VR) 2017-0241, 538-2013-8807, Karolinska Institutet, CBCS Sweden, and DDD SciLifeLab Sweden.

\section{Notes}

The authors declare the following competing financial interest(s): S.L. holds the patent, International Publication Number WO 2017/077280 AI, publication date 11 May 2017, on the use of $\mathrm{HZ}$ compounds for cancer treatment. M.H., L.J., L.S., and U.Y. are listed as inventors.

\section{ACKNOWLEDGMENTS}

The authors would like to thank Dr. Per-Anders Enquist, Umeå University, for helpful discussions about compound structures and synthesis. We would also like to thank Dr. Tanzina Mollick, Dr. Nicolas Fritz, and Dr. Anika Wiegard, Karolinska Institutet, for their valuable comments on the manuscript.

\section{ABBREVIATIONS USED}

Bax, Bcl2-associated X-protein; Bcl-2, B cell lymphoma 2; CD1 , cluster of differentiation 1; Chk-1, checkpoint kinase 1; Chk2 , checkpoint kinase 2 ; CPRG, chlorophenol red- $\beta$-Dgalactopyranoside; DCIP, 2,6-dichlorophenolindophenol; DCM, dichloromethane; DHODH, dihydroorotate dehydrogenase; DIPEA, N,N-diisopropylethylamine; DMF, dimethylformamide; DMSO, dimethyl sulfoxide; DTT, dithiothreitol; $\mathrm{H} 2 \mathrm{AX}$, histone 2 A.X variant; HATU, hexafluorophosphate azabenzotriazole tetramethyl uronium; HBTU, hexafluorophosphate benzotriazole tetramethyl uronium; HLM, human liver microsomes; HNDF, human normal dermal fibroblasts; HRMS, high-resolution mass spectrometry; HZ, tetrahydroindazoles; LDS, lithium dodecyl phosphate; $\mathrm{mdm} 2$, mouse double minute 2 homologue; MLM, mouse liver microsomes; $\mathrm{NADPH}$, nicotinamide adenine dinucleotide phosphate; PARP, poly(ADP-ribose) polymerase; PDB, Protein Data Bank; PTEN, phosphatase and tensin homologue; SRB, sulforhodamine B; TFA, trifluoroacetic acid; THF, tetrahydrofuran; Z-VAD-FMK, benzyloxycarbonyl-Val-Ala-Asp(OMe) fluoro methyl ketone

\section{REFERENCES}

(1) Jones, M. E. Pyrimidine nucleotide biosynthesis in animals: genes, enzymes, and regulation of UMP biosynthesis. Annu. Rev. Biochem. 1980, 49, 253-279.

(2) Evans, D. R.; Guy, H. I. Mammalian pyrimidine biosynthesis: fresh insights into an ancient pathway. J. Biol. Chem. 2004, 279, 33035-33038.

(3) Loffler, M.; Fairbanks, L. D.; Zameitat, E.; Marinaki, A. M.; Simmonds, H. A. Pyrimidine pathways in health and disease. Trends Mol. Med. 2005, 11, 430-437.

(4) Huisman, W. H.; Raivio, K. O.; Becker, M. A. Simultaneous estimation of rates of pyrimidine and purine nucleotide synthesis de novo in cultured human cells. J. Biol. Chem. 1980, 254, 12595-12602.

(5) Jackson, R. C.; Lui, M. S.; Boritzki, T. J.; Morris, H. P.; Weber, G. Purine and pyrimidine nucleotide patterns of normal, differentiating, and regenerating liver and of hepatomas in rats. Cancer Res. 1980, 40, 1286-1291.

(6) Sigoillot, F. D.; Berkowski, J. A.; Sigoillot, S. M.; Kotsis, D. H.; Guy, H. I. Cell cycle-dependent regulation of pyrimidine biosynthesis. J. Biol. Chem. 2003, 278, 3403-3409.

(7) Bar-Or, A. Teriflunomide (Aubagio(R)) for the treatment of multiple sclerosis. Exp. Neurol. 2014, 262, 57-65.

(8) Breedveld, F. C.; Dayer, J. M. Leflunomide: mode of action in the treatment of rheumatoid arthritis. Ann. Rheum. Dis. 2000, 59, 841-849.

(9) Dexter, D. L.; Hesson, D. P.; Ardecky, R. J.; Rao, G. V.; Tippett, D. L.; Dusak, B. A.; Paull, K. D.; Plowman, J.; DeLarco, B. M.; Narayanan, V. L.; Forbes, M. Activity of a novel 4-quinolinecarboxylic acid, NSC 368390 [6-fluoro-2-(2'-fluoro-1,1'-biphenyl-4-yl)-3-methyl-4-quinolinecarb oxylic acid sodium salt], against experimental tumors. Cancer Res. 1985, 45, 5563-5568.

(10) Sykes, D. B.; Kfoury, Y. S.; Mercier, F. E.; Wawer, M. J.; Law, J. M.; Haynes, M. K.; Lewis, T. A.; Schajnovitz, A.; Jain, E.; Lee, D.; Meyer, H.; Pierce, K. A.; Tolliday, N. J.; Waller, A.; Ferrara, S. J.; Eheim, A. L.; Stoeckigt, D.; Maxcy, K. L.; Cobert, J. M.; Bachand, J.; 
Szekely, B. A.; Mukherjee, S.; Sklar, L. A.; Kotz, J. D.; Clish, C. B.; Sadreyev, R. I.; Clemons, P. A.; Janzer, A.; Schreiber, S. L.; Scadden, D. T. Inhibition of dihydroorotate dehydrogenase overcomes differentiation blockade in acute myeloid leukemia. Cell 2016, 167, 171-186.

(11) Henao-Martinez, A. F.; Weinberg, A.; Waldman, W. J.; Levi, M. E. Successful treatment of acyclovir-resistant herpes simplex virus type 2 proctitis with leflunomide in an HIV-infected man. J. Clin. Virol. 2012, 54, 276-278.

(12) Schattenkirchner, M. The use of leflunomide in the treatment of rheumatoid arthritis: an experimental and clinical review. Immunopharmacology 2000, 47, 291-298.

(13) Haghikia, A.; Gold, R. Multiple sclerosis: TOWER confirms the efficacy of oral teriflunomide in MS. Nat. Rev. Neurol. 2014, 10, 183184.

(14) Bartlett, R. R.; Dimitrijevic, M.; Mattar, T.; Zielinski, T.; Germann, T.; Rude, E.; Thoenes, G. H.; Kuchle, C. C. A.; Schorlemmer, H. U.; Bremer, E.; Finnegan, A.; Schleyerbach, R. Leflunomide (HWA 486), a novel immunomodulating compound for the treatment of autoimmune disorders and reactions leading to transplantation rejection. Agents Actions 1991, 32, 10-21.

(15) Mattar, T.; Kochhar, K.; Bartlett, R.; Bremer, E. G.; Finnegan, A. Inhibition of the epidermal growth factor receptor tyrosine kinase activity by leflunomide. FEBS Lett. 1993, 334, 161-164.

(16) Peters, G. J.; Sharma, S. L.; Laurensse, E.; Pinedo, H. M. Inhibition of pyrimidine de novo synthesis by DUP-785 (NSC 368390). Invest. New Drugs 1987, 5, 235-244.

(17) Cody, R.; Stewart, D.; DeForni, M.; Moore, M.; Dallaire, B.; Azarnia, N.; Gyves, J. Multicenter phase II study of brequinar sodium in patients with advanced breast cancer. Am. J. Clin. Oncol. 1993, 16, $526-528$.

(18) Natale, R.; Wheeler, R.; Moore, M.; Dallaire, B.; Lynch, W.; Carlson, R.; Grillo-Lopez, A.; Gyves, J. Multicenter phase II trial of brequinar sodium in patients with advanced melanoma. Ann. Oncol. 1992, 3, 659-660.

(19) Dodion, P. F.; Wagener, T.; Stoter, G.; Drozd, A.; Lev, L. M.; Skovsgaard, T.; Renard, J.; Cavalli, F. Phase II trial with brequinar (DUP-785, NSC 368390) in patients with metastatic colorectal cancer: a study of the early clinical trials group of the EORTC. Ann. Oncol. 1990, 1, 79-80.

(20) Kulkarni, O. P.; Sayyed, S. G.; Kantner, C.; Ryu, M.; Schnurr, M.; Sardy, M.; Leban, J.; Jankowsky, R.; Ammendola, A.; Doblhofer, R.; Anders, H. J. 4SC-101, a novel small molecule dihydroorotate dehydrogenase inhibitor, suppresses systemic lupus erythematosus in MRL-(Fas)lpr mice. Am. J. Pathol. 2010, 176, 2840-2847.

(21) Diao, Y.; Lu, W.; Jin, H.; Zhu, J.; Han, L.; Xu, M.; Gao, R.; Shen, X.; Zhao, Z.; Liu, X.; Xu, Y.; Huang, J.; Li, H. Discovery of diverse human dihydroorotate dehydrogenase inhibitors as immunosuppressive agents by structure-based virtual screening. J. Med. Chem. 2012, 55, 8341-8349.

(22) Lucas-Hourani, M.; Munier-Lehmann, H.; El Mazouni, F.; Malmquist, N. A.; Harpon, J.; Coutant, E. P.; Guillou, S.; Helynck, O.; Noel, A.; Scherf, A.; Phillips, M. A.; Tangy, F.; Vidalain, P. O.; Janin, Y. L. Original 2-(3-alkoxy-1H-pyrazol-1-yl)azines inhibitors of human dihydroorotate dehydrogenase (DHODH). J. Med. Chem. 2015, 58, 5579-5598.

(23) Vyas, V. K.; Ghate, M. Recent developments in the medicinal chemistry and therapeutic potential of dihydroorotate dehydrogenase (DHODH) inhibitors. Mini-Rev. Med. Chem. 2011, 11, 1039-1055.

(24) Munier-Lehmann, H.; Vidalain, P. O.; Tangy, F.; Janin, Y. L. On dihydroorotate dehydrogenases and their inhibitors and uses. $J$. Med. Chem. 2013, 56, 3148-3167.

(25) Lolli, M. L.; Sainas, S.; Pippione, A. C.; Giorgis, M.; Boschi, D.; Dosio, F. Use of human dihydroorotate dehydrogenase (hDHODH) inhibitors in autoimmune diseases and new perspectives in cancer therapy. Recent Pat. Anti-Cancer Drug Discovery 2018, 13, 86-105.

(26) Madak, J. T.; Cuthbertson, C. R.; Miyata, Y.; Tamura, S.; Petrunak, E. M.; Stuckey, J. A.; Han, Y.; He, M.; Sun, D.; Showalter, H. D.; Neamati, N. Design, synthesis, and biological evaluation of 4- quinoline carboxylic acids as inhibitors of dihydroorotate dehydrogenase. J. Med. Chem. 2018, 61, 5162-5186.

(27) Sainas, S.; Pippione, A. C.; Lupino, E.; Giorgis, M.; Circosta, P.; Gaidano, V.; Goyal, P.; Bonanni, D.; Rolando, B.; Cignetti, A.; Ducime, A.; Andersson, M.; Jarva, M.; Friemann, R.; Piccinini, M.; Ramondetti, C.; Buccinna, B.; Al-Karadaghi, S.; Boschi, D.; Saglio, G.; Lolli, M. L. Targeting myeloid differentiation using potent 2hydroxypyrazolo[1,5- a]pyridine scaffold-based human dihydroorotate dehydrogenase inhibitors. J. Med. Chem. 2018, 61, 6034-6055.

(28) Ting, S. B.; Ng, C. H.; Bajel, A.; Hwang, W. Y. K.; Ho, S. J.; Chng, W. J.; McHale, M.; Hsieh, C. Y.; Shih, H. J.; McIntyre, N.; Kwek, J.; Chang, W. L.; Lindmark, B. Preliminary results of a phase 2a dose optimization study of ASLAN003 (DHODH inhibitor) in acute myeloid leukemia (AML) patients who are ineligible for standard therapy; early signs of activity. Blood 2018, 132, 2676-2676.

(29) Christian, S.; Merz, C.; Evans, L.; Gradl, S.; Seidel, H.; Friberg, A.; Eheim, A.; Lejeune, P.; Brzezinka, K.; Zimmermann, K.; Ferrara, S.; Meyer, H.; Lesche, R.; Stoeckigt, D.; Bauser, M.; Haegebarth, A.; Sykes, D. B.; Scadden, D. T.; Losman, J. A.; Janzer, A. The novel dihydroorotate dehydrogenase (DHODH) inhibitor BAY 2402234 triggers differentiation and is effective in the treatment of myeloid malignancies. Leukemia 2019, 33, 2403-2415.

(30) Ladds, M. J. G. W.; van Leeuwen, I. M. M.; Drummond, C. J.; Chu, S.; Healy, A. R.; Popova, G.; Pastor Fernandez, A.; Mollick, T.; Darekar, S.; Sedimbi, S. K.; Nekulova, M.; Sachweh, M. C. C.; Campbell, J.; Higgins, M.; Tuck, C.; Popa, M.; Safont, M. M.; Gelebart, P.; Fandalyuk, Z.; Thompson, A. M.; Svensson, R.; Gustavsson, A. L.; Johansson, L.; Farnegardh, K.; Yngve, U.; Saleh, A.; Haraldsson, M.; D’Hollander, A. C. A.; Franco, M.; Zhao, Y.; Hakansson, M.; Walse, B.; Larsson, K.; Peat, E. M.; Pelechano, V.; Lunec, J.; Vojtesek, B.; Carmena, M.; Earnshaw, W. C.; McCarthy, A. R.; Westwood, N. J.; Arsenian-Henriksson, M.; Lane, D. P.; Bhatia, R.; McCormack, E.; Lain, S. A DHODH inhibitor increases p53 synthesis and enhances tumor cell killing by p53 degradation blockage. Nat. Commun. 2018, 9, 1107.

(31) Liu, S.; Neidhardt, E. A.; Grossman, T. H.; Ocain, T.; Clardy, J. Structures of human dihydroorotate dehydrogenase in complex with antiproliferative agents. Structure 2000, 8, 25-33.

(32) Guo, S.; Song, Y.; Huang, Q.; Yuan, H.; Wan, B.; Wang, Y.; He, R.; Beconi, M. G.; Franzblau, S. G.; Kozikowski, A. P. Identification, synthesis, and pharmacological evaluation of tetrahydroindazole based ligands as novel antituberculosis agents. J. Med. Chem. 2010, 53, 649659.

(33) Linke, S. P.; Clarkin, K. C.; Di Leonardo, A.; Tsou, A.; Wahl, G. M. A reversible, p53-dependent G0/G1 cell cycle arrest induced by ribonucleotide depletion in the absence of detectable DNA damage. Genes Dev. 1996, 10, 934-947.

(34) Chen, S. F.; Ruben, R. L.; Dexter, D. L. Mechanism of action of the novel anticancer agent 6-fluoro-2-(2'-fluoro-1,1'-biphenyl-4-yl)-3methyl-4-quinolinecarbo xylic acid sodium salt (NSC 368390): inhibition of de novo pyrimidine nucleotide biosynthesis. Cancer Res. 1986, 46, 5014-5019.

(35) Vassilev, L. T.; Vu, B. T.; Graves, B.; Carvajal, D.; Podlaski, F.; Filipovic, Z.; Kong, N.; Kammlott, U.; Lukacs, C.; Klein, C.; Fotouhi, N.; Liu, E. A. In vivo activation of the p53 pathway by small-molecule antagonists of MDM2. Science 2004, 303, 844-848.

(36) Wang, Z.; Jonca, M.; Lambros, T.; Ferguson, S.; Goodnow, R. Exploration of liquid and supercritical fluid chromatographic chiral separation and purification of Nutlin-3-a small molecule antagonist of MDM2. J. Pharm. Biomed. Anal. 2007, 45, 720-729.

(37) Smart, D. J.; Halicka, H. D.; Schmuck, G.; Traganos, F.; Darzynkiewicz, Z.; Williams, G. M. Assessment of DNA double-strand breaks and gammaH2AX induced by the topoisomerase II poisons etoposide and mitoxantrone. Mutat. Res., Fundam. Mol. Mech. Mutagen. 2008, 641, 43-47.

(38) Tibbetts, R. S.; Brumbaugh, K. M.; Williams, J. M.; Sarkaria, J. N.; Cliby, W. A.; Shieh, S. Y.; Taya, Y.; Prives, C.; Abraham, R. T. A role for ATR in the DNA damage-induced phosphorylation of p53. Genes Dev. 1999, 13, 152-157. 
(39) Zhao, H.; Traganos, F.; Darzynkiewicz, Z. Phosphorylation of p53 on Ser15 during cell cycle caused by Topo I and Topo II inhibitors in relation to ATM and Chk2 activation. Cell Cycle 2008, 7, 3048-3055.

(40) Saito, S.; Goodarzi, A. A.; Higashimoto, Y.; Noda, Y.; LeesMiller, S. P.; Appella, E.; Anderson, C. W. ATM mediates phosphorylation at multiple p53 sites, including Ser(46), in response to ionizing radiation. J. Biol. Chem. 2002, 277, 12491-12494.

(41) Rogakou, E. P.; Pilch, D. R.; Orr, A. H.; Ivanova, V. S.; Bonner, W. M. DNA double-stranded breaks induce histone H2AX phosphorylation on serine 139. J. Biol. Chem. 1998, 273, 5858-5868.

(42) Paull, T. T.; Rogakou, E. P.; Yamazaki, V.; Kirchgessner, C. U.; Gellert, M.; Bonner, W. M. A critical role for histone H2AX in recruitment of repair factors to nuclear foci after DNA damage. Curr. Biol. 2000, 10, 886-895.

(43) Loughery, J.; Cox, M.; Smith, L. M.; Meek, D. W. Critical role for p53-serine 15 phosphorylation in stimulating transactivation at p53-responsive promoters. Nucleic Acids Res. 2014, 42, 7666-7680.

(44) Thompson, T.; Tovar, C.; Yang, H.; Carvajal, D.; Vu, B. T.; Xu, Q.; Wahl, G. M.; Heimbrook, D. C.; Vassilev, L. T. Phosphorylation of p53 on key serines is dispensable for transcriptional activation and apoptosis. J. Biol. Chem. 2004, 279, 53015-53022.

(45) Mathur, D.; Stratikopoulos, E.; Ozturk, S.; Steinbach, N.; Pegno, S.; Schoenfeld, S.; Yong, R.; Murty, V. V.; Asara, J. M.; Cantley, L. C.; Parsons, R. PTEN regulates glutamine flux to pyrimidine synthesis and sensitivity to dihydroorotate dehydrogenase inhibition. Cancer Discovery 2017, 7, 380-390.

(46) Ewald, B.; Sampath, D.; Plunkett, W. H2AX phosphorylation marks gemcitabine-induced stalled replication forks and their collapse upon S-phase checkpoint abrogation. Mol. Cancer Ther. 2007, 6, 1239-1248.

(47) Rogakou, E. P.; Nieves-Neira, W.; Boon, C.; Pommier, Y.; Bonner, W. M. Initiation of DNA fragmentation during apoptosis induces phosphorylation of $\mathrm{H} 2 \mathrm{AX}$ histone at serine 139. J. Biol. Chem. 2000, 275, 9390-9395.

(48) Solier, S.; Pommier, Y. The apoptotic ring: a novel entity with phosphorylated histones $\mathrm{H} 2 \mathrm{AX}$ and $\mathrm{H} 2 \mathrm{~B}$ and activated DNA damage response kinases. Cell Cycle 2009, 8, 1853-1859.

(49) Sarin, A.; Wu, M. L.; Henkart, P. A. Different interleukin-1 beta converting enzyme (ICE) family protease requirements for the apoptotic death of $\mathrm{T}$ lymphocytes triggered by diverse stimuli. J. Exp. Med. 1996, 184, 2445-2450.

(50) Belmokhtar, C. A.; Hillion, J.; Segal-Bendirdjian, E. Staurosporine induces apoptosis through both caspase-dependent and caspase-independent mechanisms. Oncogene 2001, 20, 33543362.

(51) Simbulan-Rosenthal, C. M.; Rosenthal, D. S.; Iyer, S.; Boulares, A. H.; Smulson, M. E. Transient poly(ADP-ribosyl)ation of nuclear proteins and role of poly(ADP-ribose) polymerase in the early stages of apoptosis. J. Biol. Chem. 1998, 273, 13703-13712.

(52) Kaminski, T.; Gros, P.; Fort, Y. Side-chain retention during lithiation of 4-picoline and 3,4-lutidine: Easy access to molecular diversity in pyridine series. Eur. J. Org. Chem. 2003, 2003, 3855-3860. (53) Walse, B.; Dufe, V. T.; Svensson, B.; Fritzson, I.; Dahlberg, L.; Khairoullina, A.; Wellmar, U.; Al-Karadaghi, S. The structures of human dihydroorotate dehydrogenase with and without inhibitor reveal conformational flexibility in the inhibitor and substrate binding sites. Biochemistry 2008, 47, 8929-8936.

(54) Frebourg, T.; Barbier, N.; Kassel, J.; Ng, Y. S.; Romero, P.; Friend, S. H. A functional screen for germ line p53 mutations based on transcriptional activation. Cancer Res. 1992, 52, 6976-6978.

(55) Lu, X.; Burbidge, S. A.; Griffin, S.; Smith, H. M. Discordance between accumulated $\mathrm{p} 53$ protein level and its transcriptional activity in response to u.v. radiation. Oncogene 1996, 13, 413-418. 